\title{
FASHIONING SUSTAINABILITY: DRAWING LESSONS FROM THE FAIR TRADE COFFEE INDUSTRY
}

BY

ANNE PRINGLE, BA, YoRK UNIVERSITY, 2009

\author{
A THESIS PRESENTED TO RYERSON UNIVERSITY \\ IN PARTIAL FULFILLMENT OF THE REQUIREMENTS FOR THE DEGREE OF \\ MASTER OF APPLIED SCIENCE \\ IN THE PROGRAM OF \\ ENVIRONMENTAL APPLIED SCIENCE AND MANAGEMENT
}

TORONTO, ONTARIO, CANADA, 2015

(C) ANNE PRINGLE, 2015 


\section{AUTHOR'S DECLARATION FOR ELECTRONIC SUBMISSION OF A THESIS}

I hereby declare that I am the sole author of this thesis. This is a true copy of the thesis, including any required final revisions, as accepted by my examiners.

I authorize Ryerson University to lend this thesis to other institutions or individuals for the purpose of scholarly research.

I further authorize Ryerson University to reproduce this thesis by photocopying or by other means, in total or in part, at the request of other institutions or individuals for the purpose of scholarly research.

I understand that my thesis may be made electronically available to the public. 


\title{
Abstract
}

\section{FASHIONING SUSTAINABILITY: DRAWING LESSONS FROM THE FAIR TRADE COFFEE INDUSTRY}

Master of Applied Science, 2015

\author{
Anne Pringle \\ Environmental Applied Science and Management \\ Ryerson University
}

Due to the fashion industry's global reach, spanning many jurisdictions, regulations are difficult to implement, monitor and enforce. Strict voluntary initiatives that focus on raising consumer awareness, thereby creating greater demand for eco fashion have greater potential to lead to reform within the fashion industry. To do so, voluntary initiatives must include clear labeling of 'eco' products and designer input, and include strict guidelines for company and designer standards. Standards must take the entire life cycle of a garment into consideration. Fashion can apply lesson from the fair trade coffee industry by appealing to consumers based on ethics and environmental responsibility through a trusted consumerfacing label. Fair trade was successful, in part, due to their recognizable label. Fair trade type certifications are most often business to consumer facing and provide consumers with the environmental and social information on the benefits of purchasing fair trade. Fair trade certification models have capitalized on large retailer involvement, allowing certifications to become mainstreamed and therefore more accessible for consumers. 


\section{Acknowledgments}

I would like to thank the following people for their support, encouragement and council through the thesis research process:

- $\quad$ Dr Kernaghan Webb, the ever-patient supervisor who encouraged my exploration in sustainable fashion, while giving me the space to come to my own conclusions.

- $\quad$ My parents for their unconditional support and encouragement through each of my varied endeavours and for instilling in me a strong value system.

- $\quad$ Hans Garoute, the employees at INDEPCO, Perez Fertil and the 10 tailors from the Local Buttons factory in Haiti for showing me the true face of fashion and providing the inspiration to create a better industry.

- $\quad$ Consuelo McAlister for partnering with me to explore sustainable fashion in theory and practice and for providing a constant source of laughter throughout the process.

- Irena Stankovic for challenging my convictions and not letting me give up.

- $\quad$ Jim Beqaj for encouraging me to find my passion in all that I do.

- Vivian Manning for providing a quiet place to write.

- $\quad$ All the leaders in the fashion industry, big and small, fighting to improve the industry for producers and consumers alike. 


\section{Table of Contents}

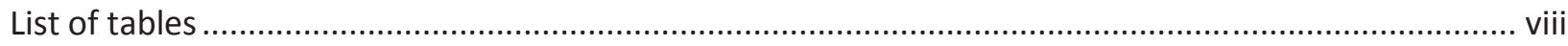

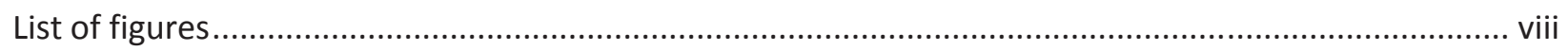

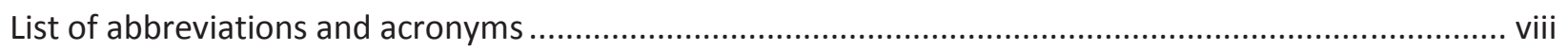

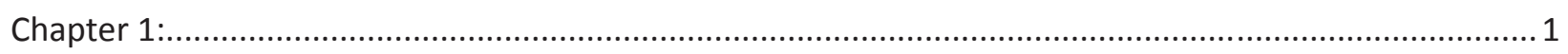

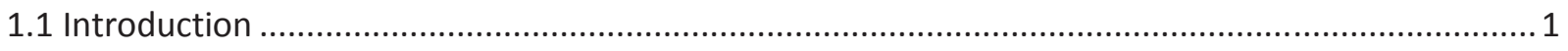

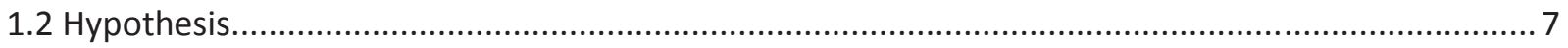

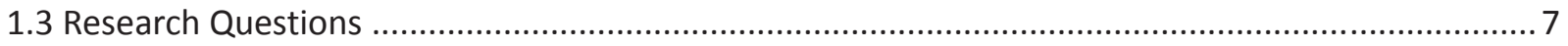

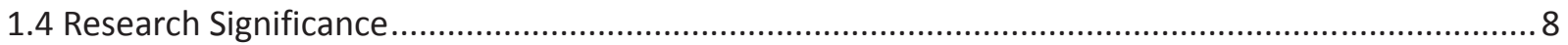

1.5. Scope

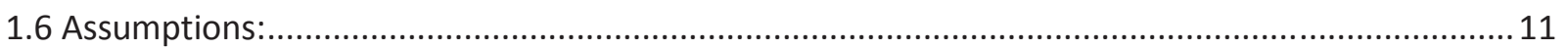

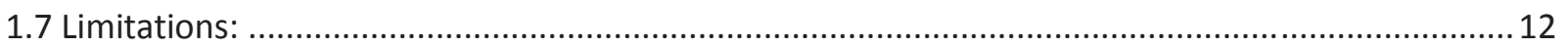

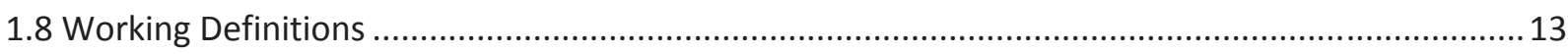

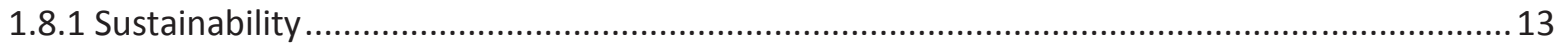

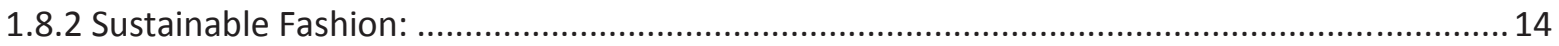

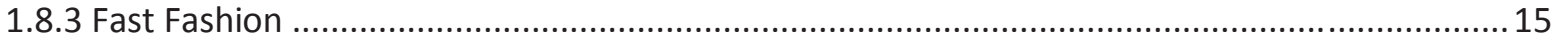

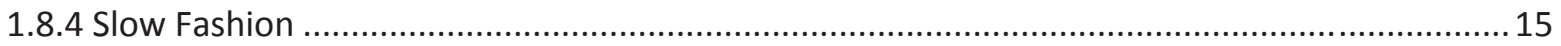

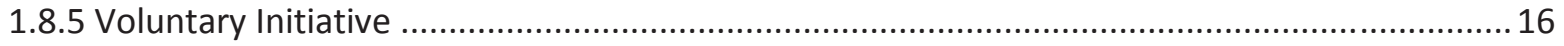

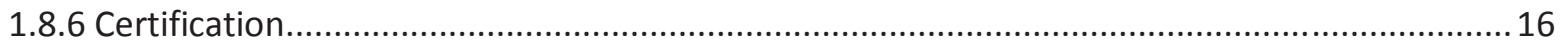

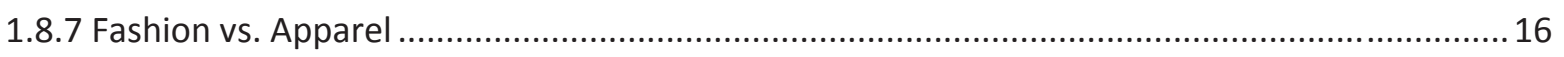

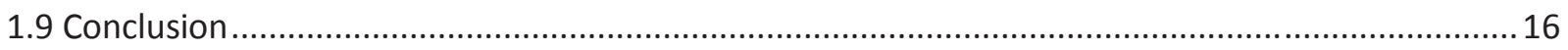

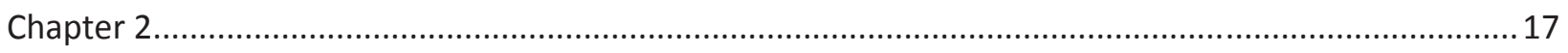

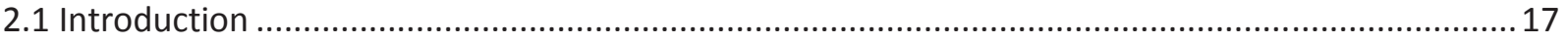

2.3 Literature Review:

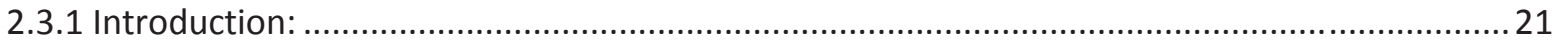

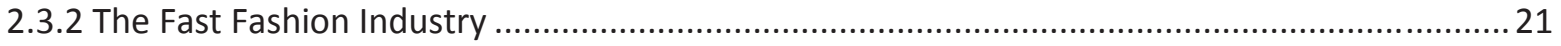

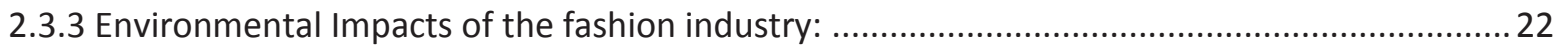

2.3.4 Lack of Consumer Awareness on the Impacts of the Fashion Industry .................................... 25

2.3.5 Sustainable Fashion a Growing Trend.................................................................................. 26

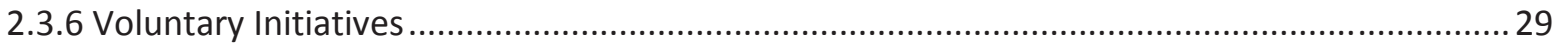

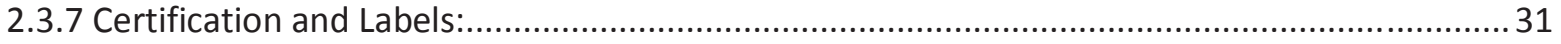

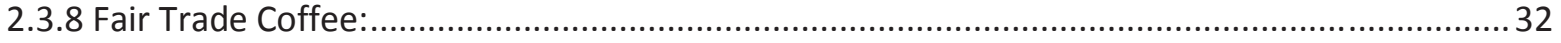

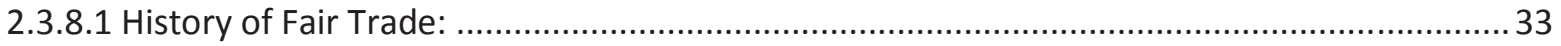




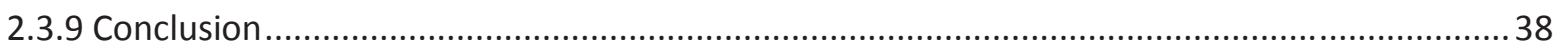

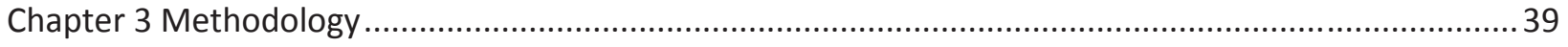

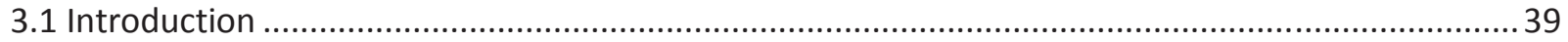

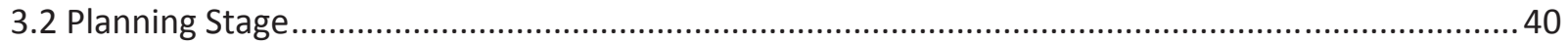

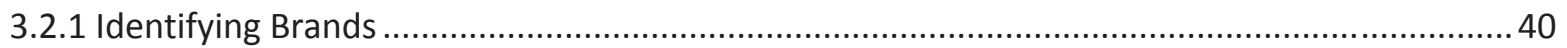

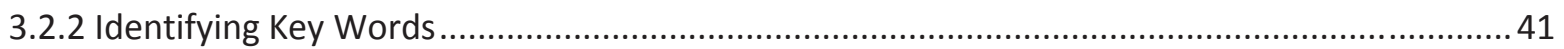

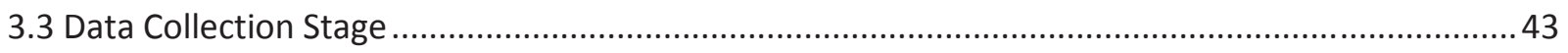

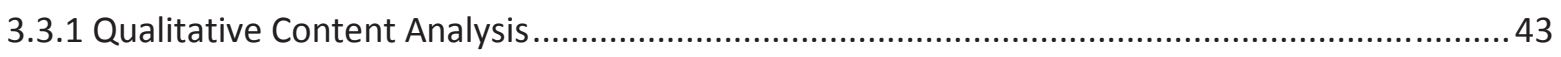

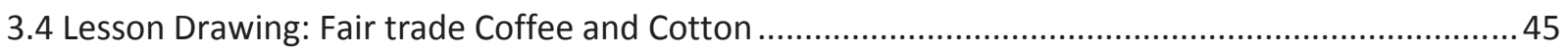

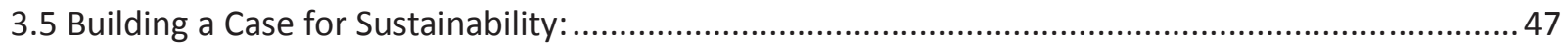

3.5.1 Role of Designers and Retailers and the case for sustainable fashion .................................. 47

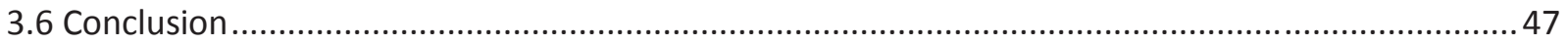

Chapter 4 Data Summary - Characteristics and Qualitative Analysis..................................................... 47

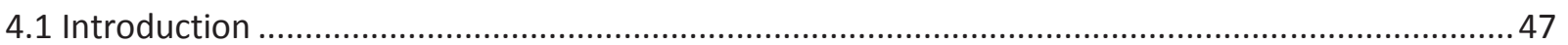

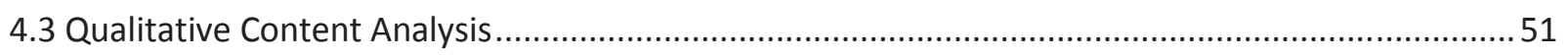

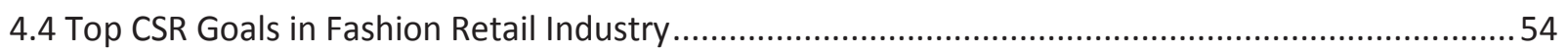

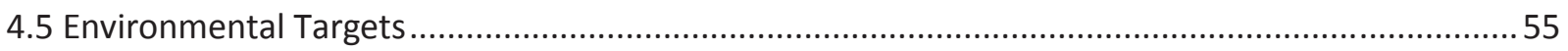

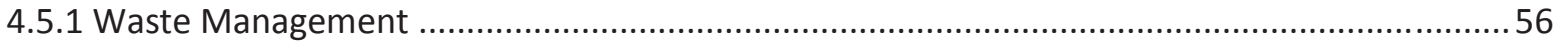

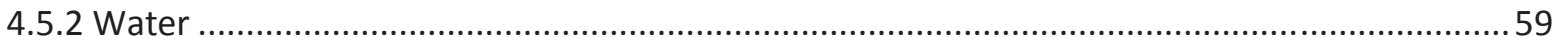

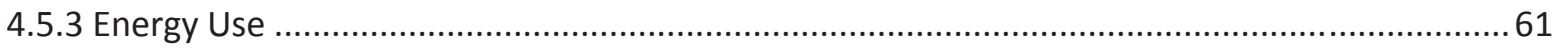

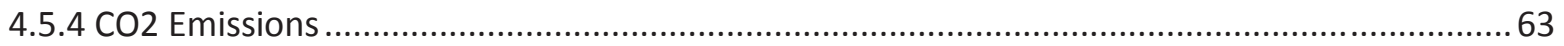

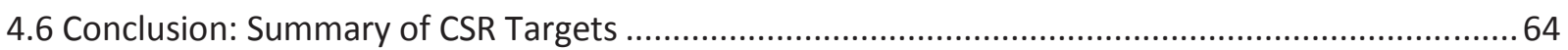

Chapter 5 Lesson Drawing: Fair Trade Coffee and Sustainable Fashion................................................67

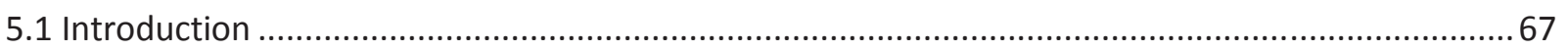

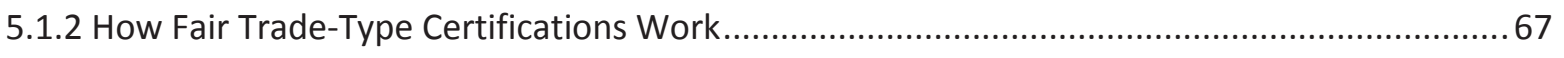

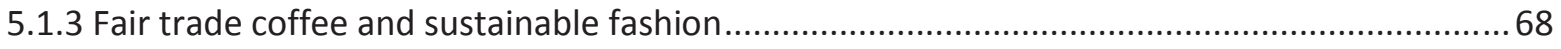

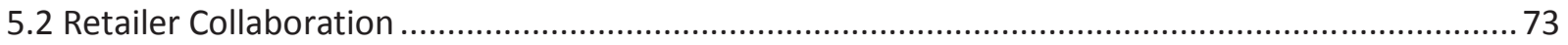

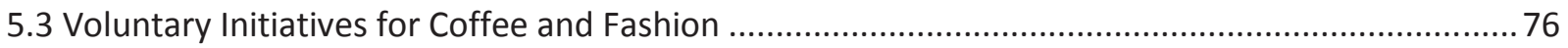

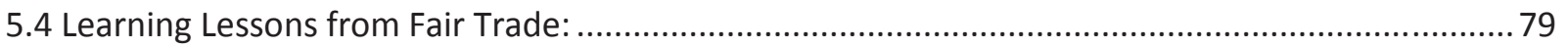

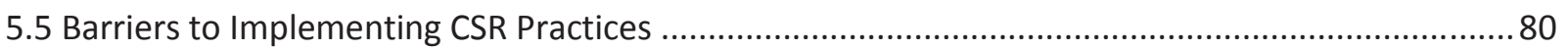

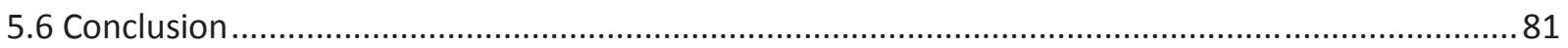

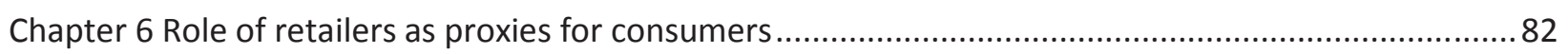

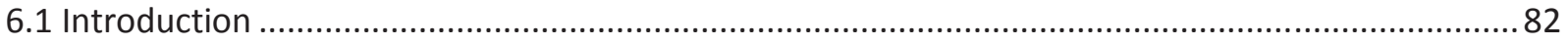




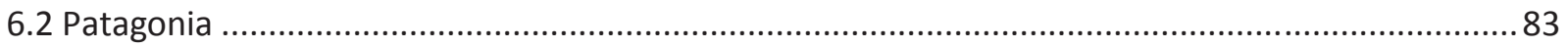

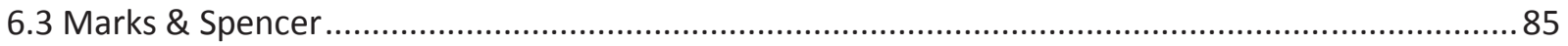

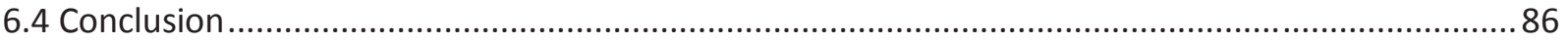

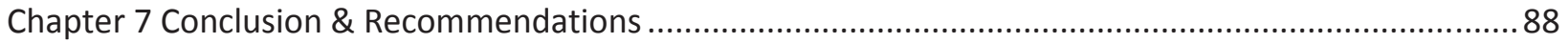

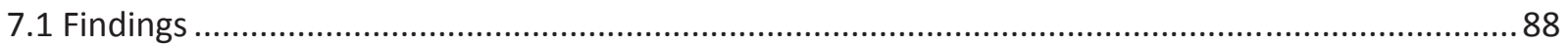

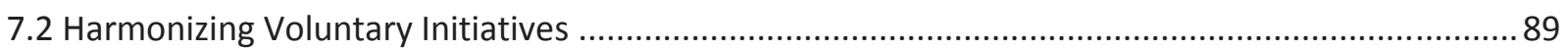

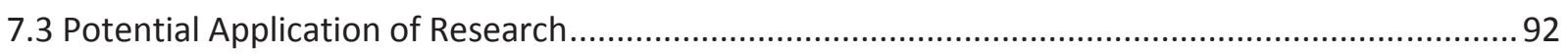

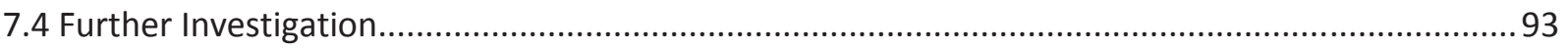

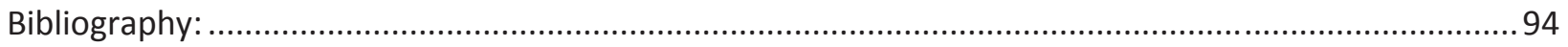




\section{List of tables}

Table 1 Sustainability definitions as stated by the sample set of retailers .............................. 15

Table 2 List of sample set of retailers and their CSR reports analyzed.

Table 3 Own Source: 100 NVivo Most Frequent 'sustainability type' words across all fashion reports from 2009-2013. Frequency tracked using NVivo software.

Table 4 Own Source: Frequency of 16 words chosen for word content analysis through

Sustainability in Retailing-a Summative Content Analysis (Wiese et al 2010) and SSI 2014 report.

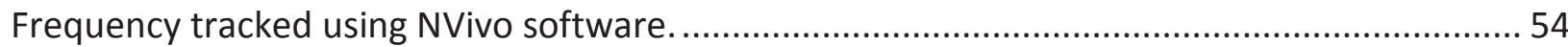

Table 5 Own Source: List of environmental VI used by the sample Retail set. ......................... 55

Table 6 Own Source: Each of the sample set of retailers reported on waste, water, CO2, and

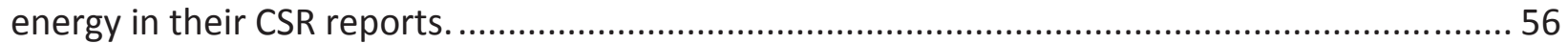

Table 7 Own Source. 2013 Waste Targets and performance across retail sample set.............. 58

Table 8 Table 4.7. Own Source. 2013 Water targets and performance across sample retail set. 61

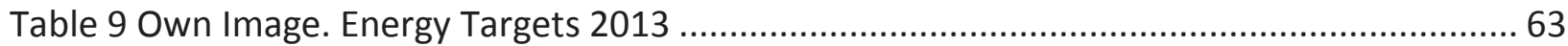

Table 10 Own Image. CO2 targets 2013 ............................................................................. 64

Table 110wn Image. Cotton and Coffee Commonalities Global coffee and cotton markets have been defined by high volatility and long term declining prices.............................................. 69

Table 12 Fair trade type certification for the coffee industry .................................................. 77

Table 13 Own image. Fair trade-type certification labels for the cotton industry..................... 79

\section{List of figures}

Figure 1 Own Source. Three ring sector view of slow fashion ............................................. 15

Figure 2 Environmental Impact of Fashion Industry throughout Supply Chain ......................... 23

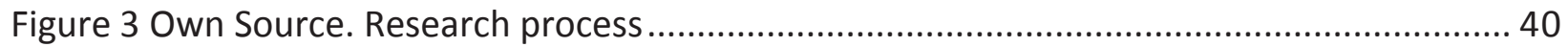

Figure 4 Own Image. Sample Retail Brand Selection and word selection for content analysis. . 41

Figure 5 Own Source: Published CSR Reports by sample set of fashion retailers...................... 51

Figure 6 Own Source: Word content use across all reports from 2009-2013. Frequency tracked

using NVivo software. ..................................................................................................... 54

Figure 7 Coffee Supply Chain. Waridel 2002; Locke, Reavis \& Cameron, 2010 ......................... 74

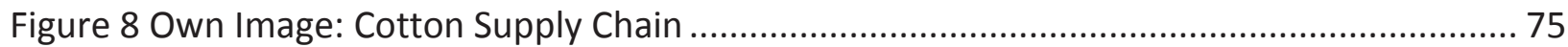

Figure 9 Timeline of voluntary initiatives in cotton and coffee industry. ................................ 79

\section{List of abbreviations and acronyms}

$\mathrm{BCl}$ - Better Cotton Initiative

CO2-Carbon Dioxide

CSR-Corporate Social Responsibility

FLO- Fair trade labeling organization

FSC- Forest Stewardship Council

GHG-Greenhouse gas

M\&S- Marks \& Spencer

NGO-Non-governmental organization

VI- Voluntary initiative 


\section{Chapter 1:}

\subsection{Introduction}

Dressing is often an international experience. Clothing often travels great distances before finding a home in our closets and draped on our backs. From production to consumption, clothing travels the globe, and personal style is frequently influenced by a diversity of cultures, norms and traditions. Fashion functions as a form of personal and artistic expression, and can function as a way to express oneself to one's surrounding community. Fashion is often celebrated for its creativity and artistic nature; however, until recently, little attention was paid to the negative environmental and social impacts of the industry.

Fashion is a major component of the world economy, requiring vast amounts of resources to supply the demand. Consumers spent an estimated 1 trillion USD on apparel in 2000 with $7 \%$ of all world exports as apparel (Allwood, 2006). The fashion industry plays a significant role in the world economy; however, within the realm of sustainability, the industry commonly operates in a way that is detrimental to the environment. Most pressing, the fashion industry uses excessive amounts of water, releases toxins into water supplies via dye baths and insecticides, and generates waste throughout production and energy use on both the producer and consumer end. The environmental impacts of the fashion industry are felt throughout three stages; textile production, manufacturing and consumer use and disposal.

The textile industry is one of the industries with the longest and most complicated industrial chains of the manufacturing industry. It involves actors from the agricultural, chemical fiber, textile, and apparel industries, retail and services sector, and waste treatment. The industry is fragmented and heterogeneous, dominated by small and medium enterprises (SMEs) which account for more than $80 \%$ of the market (European Commission Report, 2011, p. 4)

Textile production often generates the greatest environmental impacts throughout the fashion supply chain. Cotton, the most widely used textile in the fashion industry, is often referred to as the 'dirtiest crop' as it covers only $2.5 \%$ of cultivated land, yet uses $16 \%$ of all insecticides sprayed worldwide (Salerno-Kochan, 2008). Cotton production uses the third highest amount of pesticides worldwide with over 81 million pounds sprayed each year in the US alone (USDA, 1999). In addition to the negative environmental impacts of harvesting cotton, the invasive dyeing process of cotton fabrics creates toxic waste. Cotton production generates environmental damages through the prominent use of pesticides, fertilizers and crop defoliants (Kadolph, 2010). 
The stages for cotton textile production are: agriculture, fiber production, processing yarn preparation, fabric production, bleaching, dyeing and printing and finishing. Each stage creates waste requiring proper management and has the potential for overall waste reduction (MIGA 1996). Water consumption and toxic wastewater remain the greatest sources of environmental degradation in cotton production. Throughout the cotton production process, the compounded average volume of wastewater created is $365 \mathrm{~m}^{3}$ per metric tonne (Tüfekci, 2007). Despite depleting global water resources and the known negative impacts of conventional cotton production, cotton remains the choice fabric for designers and retailers due to its versatility.

Cotton production processes require massive amounts of water, thereby stressing and depleting water resources. Twenty gallons of water are required to produce one pound of product suitable for textile production (Rehman \& Shafiq, 2000). Cotton generates pollution throughout the production chain resulting in toxic wastewater, air pollution and solid waste. Much of the cotton production process involves the use of solvents in the wet processing. These solvents create pollution mainly in the form of emissions of volatile organic compounds (VOC) created through the dyeing and finishing processes (MIGA, 1996). Wastewater is a toxic byproduct of cotton processing created from the dyeing process and pesticide use during the agricultural phase. Air emissions generated throughout the production process include: dust particles, oil mists, acid vapors and odors (MIGA 1996). According to the World Bank, $17-20 \%$ of industrial water pollution is due to the dyeing and treatment of textiles.

In many textile operations waste from seam cutting and trimming account for more than $2 \%$ of fabric produced resulting in several thousand yards of fabric waste per week in a factory that produces a million yards of fabric per week (EPA 1996). The US produces 800 million yards of denim (made from cotton) each year, equaling roughly 1.5 billion pounds of denim. Cutting efficiency for denim ranges from $72-94 \%$, averaging at an $84 \%$ efficiency rate. Therefore, cutting waste from denim in the US accounts for 100 million pounds of solid waste alone (EPA 1996). Solid waste is generated in both production phase and consumer phase in the lifecycle of cotton garments.

Consumer use and disposal of fashion generates environmental impact. In the U.S. each year 4.5 million tonnes of clothing and footwear are produced, requiring millions of gallons of water for production. Currently, garments are created quickly and poorly often ending up in the landfill within a year of 
purchase. Of the 4.5 million tonnes of textiles produced each year, only 1.25 million are recovered for future use, either up-cycled into new garments or down-cycled to second hand clothing (Rehman \& Shafiq, 2000). The mass production of fashion fills landfills, requires large volumes of water and creates toxic wastewaters through the excessive use of pesticides and toxic dyestuffs (Kadolph, 2010).

Historically, the fashion industry has not had any particular focus on ethics and social standards. The industry searches for the cheapest sources of labour and materials. Multinational companies seek ways to reduce the bottom line, often at the cost of both their employees and the environment. The fashion industry is widely dependent on a business model where Western retailers and designers subcontract their production, often to developing countries where standards and regulations are most often less stringent. As of yet, a conventional regulatory approach has not yet been successful in addressing the environmental or social impacts presented by global fashion sector (Webb, 2004). Subcontracting manufacturing to developing countries can make monitoring difficult, as laws are often weak or poorly enforced which can lead to a lack of transparency throughout the supply chain. This lack of transparency in part has led to a decrease in accountability throughout the supply chain, further impacting the environmental and social impacts generated by the fashion industry (Kozlowski, Bardecki and Searcy 2012).

The negative social impacts generated by the fashion industry include the use of child labour, poor pay, long hours, barriers to unionize, no pay for overtime, deplorable working conditions including lack of training, 'sweatshop labour conditions', exposure to chemicals and unsafe buildings. The collapse of the Rana Plaza garment factory in Bangladesh in April 2013, where over 1,100 factory workers lost their lives, highlights the inadequacy of Bangladeshi health, safety and building integrity laws and the difficulty in enforcing these laws from abroad. Rana Plaza highlights the inadequacy of current social standards within the fashion industry and the inadequacy of international regulation. There are significant social impacts associated with the production of apparel. A comprehensive sustainability voluntary initiative for the fashion industry should address both the social and the environmental impacts. The focus of this Environmental Applied Science and Management Masters thesis paper is on the environmental dimensions of the fashion industry, and the value of development of a voluntary initiative to address the environmental dimensions, but at the same the author fully recognizes that a comprehensive sustainability voluntary initiative for the fashion industry needs to address both the environmental and social dimensions of the apparel sector. 
Voluntary initiatives have become a focal point for retailers as a way to address the environmental and social concerns. Apparel and textiles closely tie the developed and developing world together. The developing world produces half of all textiles exports and three quarters of the world's clothing exports. In addition, the textiles and apparel industries provide 26.5 million people with work; this excludes those working in retail or supporting sectors (Allwood, 2006). The industry transcends borders and sectors, directly impacting the livelihoods of millions of producers and their families.

Globalization presents a duality for the fashion industry. On one side, globalization has led, in part, to the diversification of the fashion industry where companies subcontract their work to developing countries due to more lenient environmental laws and cheaper labour. On the other side, globalization has led individuals around the world feel more connected to each other. Through the Internet and social media, including twitter, YouTube, Facebook and Instagram, consumers are connected more than ever to the brands they purchase. Globalization has led to provide communication tools and a network for NGO campaigns to strengthen their message and reach more consumers. Following the collapse of Rana Plaza, images of the tragedy made their way around the globe instantly, resulting in outrage from consumers. The connectedness of the world through social media could play an integral role in strengthening a voluntary initiative for the fashion industry.

The subcontracting of the manufacturing phase is done independently of the company, making monitoring the process more difficult for designers and retailers. On an international scale, subcontracting manufacturing to factories offshore often makes monitoring difficult to implement and uphold. Due to the often less stringent environmental laws where fashion is manufactured and the transient nature of fashion where garments traverse multiple borders throughout their lifecycle, regulation is difficult. Voluntary initiatives could provide the mechanism to address the environmental issues presented by the fashion industry. As of yet, there does not seem to be a holistic and cohesive voluntary initiative that addresses the entire lifecycle of the fashion industry.

The fashion industry was built on a history of poor working conditions and an emphasis on financially efficient manufacturing, often resulting in processes that are harmful to the environment. While the fashion industry has always generated negative environmental impacts, today's fast fashion model, defined as affordable basics and disposable trends produced quickly in a cost efficient manner (Cachon 
\& Swinney, 2011), accentuates these impacts. Fast fashion produces incredible product variety created by a complex and long supply chain with short product life cycles and unpredictable demand (Siegle, 2011). The fashion industry as we understand it today is a product of the modern age. Prior to the mid$19^{\text {th }}$ century most clothing was custom made for individuals by either dressmakers or tailors. With the invention of the sewing machine in the early $20^{\text {th }}$ century and the rise of global capitalism the fashion industry began to shift towards ready to wear clothing. The development of factories and the growth of department stores and retail outlets allowed clothing to become mass-produced. This eventually gave way to offshore manufacturing, with multinational setting up factories in developing countries in order to decrease labour costs. As the fashion industry has evolved it has become increasingly global. The diversification of the fashion supply chain has given way to the current fast fashion model, where production often happens at subcontracted factories. Garments are now created by fabrics that might have been grown in the US, milled in India, sewn in China and sold to the Canadian market.

Over the past two decades, fashion has become increasingly available across all socio-economic sectors due to the development of 'fast fashion' (Klein, 2012). Fast fashion continues to dominate retail sales. The evolution of the fashion industry has led to today's fast fashion industry where over 52 microseasons exist (Siegle, 2011). The development of fast fashion has led to an increase in fashion purchases with Canadians spending an average of 21.5 billion on apparel and footwear each year. Clothing purchase costs account for $5.8 \%$ of total expenditure (Statistics Canada, 2009). This increase in demand for fast fashion has led to increase the negative environmental and social impacts generated by the fashion sector. The recent move toward fast fashion has accentuated these environmental impacts by creating cheap fashion that consumers are purchasing at an ever-increasing rate. The industry in general is environmentally intensive and, 'fast fashion' is simply the latest manifestation of the industry. This increases environmental impacts throughout the manufacturing supply chain (textile production and manufacturing) and most notably in the end-of-life, disposal phase.

Regulation of the global fashion industry involves actors from government, civil society, the private sector, consumers, designers, academics and the agricultural sector and others in a complex series of inter-relationships. Due to its complexity and the difficulty of international monitoring, there exists a myriad of certification codes and voluntary initiatives for the fashion industry. Yet these codes remain fragmented, rather than applying a cohesive approach analyzing the entire supply chain right from agriculture through to consumption and disposal (Gam, 2007). The Greenpeace Detox Challenge, 
launched in 2011 calls on companies to become toxic free by reducing toxic effluents by 2020 (Greenpeace, 2011). The Better Cotton Initiative $(\mathrm{BCl})$ promotes the use of organic cotton in conventional apparel processes (Better Cotton Initiative). Others focus on improving the social element of the fashion industry; such as Fair trade Certification of cotton and factories. The Sustainable Apparel Coalition is an industry led campaign that addresses both social and environmental impacts along the fashion supply chain. However, the Sustainable Apparel Coalition is self-monitored and regulated by participating industry members, leaving consumers wary of green washing.

International regulation for the fashion industry has yet to be implemented. For example, Canada lacks a regulatory process within the fashion industry to both monitor and uphold environmental and social protection laws internationally. The fashion industry's international reach, transcending multiple jurisdictions, makes regulation difficult to implement, monitor and enforce (Gam, 2007). Regulation can function as a tool for policy reform, however; strict regulation such as 'command and control' regulation is a rigid, and one size fits all approach that often does not encourage innovation within industries. Voluntary initiatives that encourage innovation for within the industry are need to work with regulatory reform. Command and control regulation can also lead to a 'free license' to pollute to those in compliance with standards, consequently not encouraging innovation (Greenbaum \& Wellington, 2010). The multitude of stakeholders within the fashion sector, spanning multiple jurisdictions, from consumers, farmers, designers, and producers to legislators and policy officials may prove to make regulation ineffective and very costly to monitor. Scientists can help create clarity in this arena for consumers by providing a straightforward analysis of the negative environmental impacts of the fashion industry. Scientific expertise is needed in order to create an informed public who can then take the conscious steps to advocate and demand for corporate compliance to standards within the textiles industry (Gam, 2007).

Currently, regulations involving the use of certain toxic chemicals exist but are very difficult to uphold. For example, the European Union (EU) has regulated the use of carcinogenic azo-dyes both for their use within EU countries and for the importation from any country that used azo-dyes in their processing (Rehman T. et al., 2000). Canada has expressed concern regarding the use of azo-dyes proven to be carcinogenic. However, regulations have yet to be implemented to enforce and monitor when textile production occurs internationally. Canada lacks strict regulatory reform for detecting and prohibiting the importation of textiles contaminated by azo dyes. 
While there exists a myriad of sustainable and socially conscious initiatives, it appears there currently lacks a comprehensive code that addresses the entire lifecycle of a garments from creation to disposal. Addressing the lifecycle of a garment is integral to addressing environmental concerns throughout the supply chain (Kozlowski, Bardecki \& Searcy, 2012). This paper will address issues highlighted in existing apparel codes, specifically focusing on cotton production and highlight the deficiencies. The current amount of codes and initiatives in existence can lead to audit fatigue, are not well marketed, lack a similar language and are not trusted or known by consumers (Gam, 2007). The fashion industry often operates to the detriment of the natural environment due to a lack of regulation throughout the supply chain. In addition, within the fashion industry sustainability has often been perceived as an obstacle rather than an economic choice for fashion designers and retailers (Siegle, 2011).

\subsection{Hypothesis}

If the fashion industry adopts strict ${ }^{*}$ voluntary initiatives that focus on raising consumer awareness, thereby creating greater demand for eco fashion then there is greater potential to lead to reform within the fashion industry. To do so, voluntary initiatives must include clear labeling of 'eco' products and designer input, combined with strict guidelines for company and designer standards. Providing transparency throughout the supply chain in conjunction with designer and retailer promotion of stylish \& sustainable fashion could lead the fashion industry to shift towards wider adaptation/implemention of sustainable practices (Ashby, Hudson Smith \& Shand, 2013). If the fashion industry adopts lessons from the fair trade coffee industry, it could appeal to conscientious consumers with the guarantee that by purchasing sustainable fashion the value is shared throughout the supply chain, mitigating environmental damage caused by manufacturing.

\subsection{Research Questions Central Questions:}

What are the four (4) common goals for leading sustainable fashion brands in Canada? What are the trends in sustainable reporting by large retail brands?

What role can retailers and designers play in mainstreaming sustainable fashion?

\footnotetext{
* A strict voluntary initiative refers to an initiative that upholds stringent environmental and social standards. A strict initiative would have clearly detailed rules and codes for retailers to adhere to in order to be considered compliant. A strict voluntary initiative would outline detailed reporting methods and data collection tools.
} 
What lessons can the fashion industry learn from Fair trade type certification schemes used in the coffee industry?

\section{Sub Questions:}

What role can designers and retailers play to improve the sustainable fashion industry? Is sustainable fashion economically feasible? Is there a business case for sustainable fashion?

\subsection{Research Significance}

This study will research the feasibility of mainstreaming sustainable fashion by looking at the business case for sustainable fashion. Research looks at existing voluntary initiatives within the Canadian textiles industry in regards to sustainable (eco-friendly and ethical) fashion. This research aims to illuminate the shortcomings of existing voluntary initiatives and make suggestions for reform. Research will focus on issues such as how voluntary initiatives are understood at both the industry and consumer level and the potential role designers and retailers can play in shaping industry sustainability standards.

This study aims to investigate how fair trade type certification and labeling for coffee, a successful and more comprehensive voluntary initiative with clear messaging, can function within the fashion industry to make it easier for retailers, designers, consumers and manufacturers to participate. Therefore, potential benefits of this paper include the potential for the greater incorporation of the fair trade type labels for fashion, in order to generate consumer confidence in sustainable fashion. The fair trade label is proposed as an umbrella term that will make it easier for manufacturers, retailers, designers and consumers alike to understand the social and environmental benefits of sustainable fashion. Research will look at companies that are compliant with fair trade type certification programs.

Voluntary initiatives (VI) are becoming progressively more prevalent in consumer society and have become increasingly important over the past 20 years. VI represent an underlying shift or trend in the market reflecting the legal structure of the market place. An increase in voluntary initiatives demonstrates the demand side looking for indications that a product has sustainable characteristics. Voluntary initiatives can function as a systematic approach to structuring environmental, social and economic impacts of a product (Webb, 1999). FLO remains a major player in the production and sales of sustainable coffee. In 2012, FLO represented $10 \%$ of total certified or verified production and $5 \%$ of global coffee production (Potts et al, 2014). The fashion industry has begun to take note with Patagonia 
and MEC launching Fair trade lines in 2014 and Oliberte becoming the first Fair trade Certified shoe factory in Africa.

Like what Fair trade type certifications did for coffee, the fashion industry can adopt a single umbrella term and labeling to clearly outline and define sustainability in the fashion industry. To do so, a VI for the fashion industry must include clear labeling of 'eco' products and designer input, and include strict guidelines for company and designer standards. To be successful, standards must take the entire life cycle of a garment into consideration (Kozlowski, Bardecki \& Searcy, 2012).

Research will track trends in sustainability reporting among five (5) prominent fashion retailers between 2009 and 2013. Trends will be tracked based on word usage in corporate social responsibility reports and specific environmental targets set out by the retailers investigated.

\subsection{Scope}

This research critically examines the existing fashion industry, highlighting areas of improvement that current voluntary initiatives (V.I.) relevant to the fashion industry can address. Their shortcomings will be assessed and will be compared with the well-established and mainstreamed fair trade type certification for coffee. The research looks beyond voluntary initiatives in the fashion industry to fair trade type labeling for insights and ideas learned as voluntary initiatives for the fashion industry are an emerging field (Gardetti \& Torres, 2013). In chapter 5 research will critically assess current programs to determine where reform could be most beneficial. Additionally, research will examine which policy tools are most effective to achieve greater environmental awareness, thereby lessening the deleterious global impact of the fashion industry. The paper will discuss how and if voluntary initiatives and consumer demand for 'eco-friendly' fashion can be an effective means to lead to an increase in the creation and consumption of sustainable fashion. Research looks to illuminate the unique role designers and retailers can play in order to help initiate this change.

Fair trade-type certification programs refers to third party certification programs that address both social and environmental issues. Fair trade type certification includes Fair Trade USA (formerly TransFair) Fair trade International (FLO), UTZ and 4C Association. These fair trade type programs have developed a set of standards addressing ethical and environmental issues throughout the coffee supply chain, and assure conformity with these standards through third party monitoring. Fair Trade USA, FLO, UTZ and 4C 
Association will be discussed further in chapter 5. Initiatives were chosen from State of Sustainability Initiatives (SSI) 2014 report (Potts et al, 2014). Launched in 2008, SSI releases leading industry reviews through a partnership between the International Institute for Environment and Development (IIED) and Aidenvironment.

In order to address the above research questions, research will rely on industry reports of fashion retailers who have released public reports and documents for the reporting periods from 2009-2013. Research will highlight key trends across five (5) leading brands, Adidas, Gildan, H\&M, Inditex and NIKE, in sustainable fashion and cross-reference their claims against reporting and benchmarking metrics by Sustainalytics Top 50 Socially Responsible Corporations 2014. Following the identification of key sustainable players in the fashion industry, research will undertake three methodologies:

1. Qualitative Content Analysis of publicly available sustainability reports from the reporting periods of 2008-2012 using NVivo Software to demonstrate trends in reports.

2. Lesson-drawing from fair trade type certification schemes for the coffee industry that the fashion industry can adopt and learn from.

3. Highlight leading brands, Marks \& Spencer and Patagonia to demonstrate the feasibility of sustainable fashion.

Current voluntary initiatives for the fashion industry will be highlighted in comparison to fair trade-type certification through lesson drawing. The fair trade label has become a recognizable and trusted label among consumers, specifically for coffee, tea, chocolate and sugar (Fair Trade Canada, 2012). As such, the Fair trade labeling and certification will be used to compare and contrast current initiatives within the fashion sector. Fair trade coffee and the fashion industry share similarities as both deal with consumable goods often produced in a developing nation where environmental and labour standards are lower than where they are sold in the market (Fair Trade Canada, 2012). Fair trade functions as a comparable initiative for the fashion industry and can provide insight through lessons learned that the fashion industry can adopt. Fair trade certification and labeling initiatives are not without their faults; these faults will be highlighted throughout the research.

Fair trade certification is a business to consumer model allowing retailers to function as proxies for consumers. Since its official inception in 1997, Fair trade has gained a remarkable part of the market place for sustainable purchasing. Fair trade products and sales continue to increase yearly. Fair trade has 
extended to coffee, sugar, tea, chocolate and even cotton (Fair Trade Canada,2012). Fair trade coffee in particular was chosen to compare to the fashion industry, specifically cotton production, as both coffee and cotton present similarities. While the comparison is not perfect, the similarities outnumber the differences. Coffee and cotton are both resource intensive crops requiring vast amounts of water and pesticides. Both coffee and cotton are agricultural crops relying on low cost labour, predominantly in developing countries, with the exception of some cotton grown in the US. Coffee was chosen over the organic food movement, as consumers do not directly link sustainable coffee or sustainable cotton and clothing with health. Sustainable fashion must appeal to consumers on the grounds of ethics and environmental sustainability the way fair trade coffee has. They do present some differences; there are specific coffee retail shops that engage directly with consumers while there are no cotton shops. However, there are sustainable fashion retailers that can engage directly with consumers, the way small fair trade coffee shops have, thus acting as proxies for consumers.

In order to properly compare the fashion initiatives to that of fair trade certification a set of guidelines has been developed Voluntary initiatives will be assessed based on the following: mission, history, commercial conditions, supply chain traceability, certification method, and consumer communication and retailer involvement. Research will seek to demonstrate that 'green' methods adopted for the manufacturing of cotton can prove to be beneficial for the apparel industry, consumers and the environment alike (Moore, 2004). Creating a straightforward labeling process, one that adheres to a comprehensive voluntary initiative, will help to inform consumers on how to purchase more sustainable products. According to Gam (2007) consumers are willing to purchase 'green' (sustainable) products, but are often confused by labels. A number of consumers appear to find product labels hard to understand. Research has found that there are consumers who will buy lower quality green products in comparison to alternative products, but only when environmental information is clearly stated on labels ( $D$ 'Souza et al., 2006). Price sensitive eco consumers, who claim to always read labels, expressed that when purchasing 'eco' products, their decisions are based on sufficient and straightforward information displayed on product labels (D'Souza et al., 2006). Retailers can help in the process by acting as an important proxy for consumers.

\subsection{Assumptions:}

Eco-fashion, while still a niche market, is a growing trend. As consumer awareness of the harmful impacts of the fashion industry increases, consumers and NGOs are beginning to pressure companies to 
take greater responsibility to develop sustainable practices. Despite this rising awareness, consumers do continue to purchase cheap, 'fast' fashion in large quantities and it continues to dominate retail sales (Cachon \& Swinney, 2011). While consumers are slowly becoming increasingly aware of the negative environmental and social impacts of the fashion industry there continues to be a dichotomy between what consumers claim they want versus what is actually purchased (Gam, 2007). The desire to acquire the newest trend at the cheapest price remains the driving factor for the majority of consumers who spend an estimated \$21.5 billion on fashion each year (Stats Canada, 2009). Research assumes that fast fashion will continue to remain the prevalent driving force of the fashion industry; therefore, addressing the large fast fashion retailers is imperative to mitigating the environmental risks associated with the fashion industry. Research also assumes, that clear labels demonstrating greater transparency throughout the supply chain will generate greater consumer confidence in sustainable fashion and lead to an increase of consumer purchasing of sustainable fashion.

The current fast fashion model is based on the selling the newest trend, and research assumes that sustainable fashion will continue to gain momentum as large retailers, designers, celebrities and academics are beginning to shed more light on the impacts of the fashion industry. Mainstream sustainable fashion is catching on, and is gaining momentum each fashion season. Research assumes that fast fashion retailers will continue to engage with sustainable initiatives and continue to report on their environmental impacts.

\subsection{Limitations:}

Textile production and manufacturing is a large and diverse industry, transcending multiple jurisdictions and making monitoring difficult (Gam, 2007). The limitations in research include the difficulty of accurately monitoring regulation for the fashion industry on an international scale. Research will focus primarily on voluntary initiatives rather than regulatory processes, as regulation across multiple jurisdictions is difficult to monitor and uphold.

A wide variety of fabrics are used within the fashion industry, both synthetic and organic. Each textile generates an environmental and social impact throughout their supply chain. The use of synthetic fibers such as polyester and nylon release significant amounts of Green House Gases (GHG) through the use of fossil fuel (DEFRA, 2011) and are non-biodegradable. For the purpose of this paper research will focus on the use of cotton, the most widely used fiber for garment production. Cotton generates significant 
impacts throughout its supply chain through waste, energy, water and pesticides. More environmentally friendly options of cotton are becoming more available with the likes of organic cotton and better cotton (through the Better Cotton Initiative). Research looks to highlight advances made in the production of sustainable cotton.

Many voluntary initiatives exist that address environmental and or social concerns. The building sector has LEED certification, the paper sector has FSC certification, and the Diamond industry has the Kimberely Accord. All are voluntary based initiatives aimed to improve either the social or environmental standards within their industry. For the purpose of this research, fair trade type coffee certification was chosen over other labels; as fair trade has already begun to integrate with the fashion industry, specifically cotton. Cotton and coffee offer many parallels and allow for a comparison between the two industries. Further information on the comparison of coffee and cotton is provided in Chapters 3 and 5.

Five fashion retailers selling in Canada are highlighted for their sustainable initiatives and their environmental commitments. Their CSR reports are compared and analyzed based on the firms' environmental commitments to energy, waste, water and $\mathrm{CO} 2$. The five retailers provide a sample of fashion retailers but offer limitations as all are either fast fashion specialty retailers (H\&M and Inditex), or sports apparel retailers (Adidas, Gildan and NIKE). Research did not track trends among small, independent designers or high-end fashion retailers, but instead focused on fast fashion.

The fashion industry presents negative environmental and social impacts, however, while this paper will briefly highlight areas of social concern, the main focus will remain on the environmental impacts of the fashion industry. It is important to note that a comprehensive voluntary initiative and code for the fashion industry must incorporate both strict environmental and social standards (Ashby, Hudson Smith \& Shand 2013). Fair trade type certification models incorporate both social and environmental standards and are currently used for a variety of agricultural products including a small amount of cotton production.

\subsection{Working Definitions}

\subsubsection{Sustainability}

There are many definitions for sustainability. For the purpose of this research, the definitions as set forth by the Brundtland Report in 1987 will be used. The Brundtland Report states that sustainability is a 
process that 'meets the needs of the present generation without compromising the ability of future generations to meet their own needs' (UN 1987). This paper will examine the potential intergenerational effects of current fast fashion by investigating the negative environmental and social impacts of the long-term implications of the fashion industry. Sustainable fashion, as discussed in this thesis, refers to a process, which respects people and the planet while remaining economically feasible. Sustainable fashion encompasses the entire supply chain-from agricultural production, fiber processing, design, retail and consumption. Sustainable fashion looks at environmental protection, protection for workers involved throughout the supply chain and at economic efficiency.

\subsubsection{Sustainable Fashion:}

Sustainable fashion is a process that respects the people and planet while remaining economically feasible. Sustainable fashion encompasses the entire supply chain from agricultural production to fiber processing, design, retail and consumption.

Relating the concept of sustainability to clothing means that ideally this would be clothing which meets the needs of today's consumers, and is also made, transported, sold, used and disposed of in ways which do not adversely impact people or the planet - now or at any time in the future (DEFRA 2011 pp3).

The International Standards Organization (ISO) has defined eco-fashion as Identifying the general environmental performance of a product within a product group based on its whole life-cycle in order to contribute to improvements in key environmental measures and to support sustainable consumption patterns.

Table 1.1 below outlines how the sample set of retailers each define sustainability.

\begin{tabular}{ll}
\hline Retailer & Definition \\
\hline Adidas & Four pillars of sustainability; people, product, planet and \\
partnership. Responsibility to be fair to future generations and \\
improve systems and processes so that Adidas and supplier \\
cause less harm to the planet.
\end{tabular}




\begin{tabular}{ll}
\hline Gildan & '...A heightened sense of responsibility to preserve our existing \\
environmental resources and, as well, to develop processes \\
designed to reduce as much as possible the effect of our \\
activities on our physical surroundings'.
\end{tabular}

Table 1 Sustainability definitions as stated by the sample set of retailers

\subsubsection{Fast Fashion}

Refers to cheap alternatives that mimic luxury brands. Fast fashion offers affordable basics and disposable trends produced quickly and in a cost efficient manner (Cachon \& Swinney, 2011). The lowcost clothing based on the latest trends, is by nature a fast-response system that encourages disposability (Fletcher, 2007). Once an industry that relied on Spring/Summer and Fall/Winter seasons, fast fashion now hosts 52 micro seasons. Large retailers such as H\&M and Forever 21 receive daily shipments of garments and TopShop boasts 400 new styles online each week (Siegle, 2011).

\subsubsection{Slow Fashion}

Slow fashion is not a seasonal trend that comes and goes, but a sustainable fashion movement that is gaining momentum. Slow fashion looks at the entire lifecycle of a garment, promoting sustainability throughout the supply chain. It encourages education about the garment industry's connection to and impact on the environment and depleting resources. Slow fashion promotes a slowing down of the supply chain to reduce the number of trends and seasons, to encourage quality of production, and return a greater value to garments by removing the image of disposability of fashion. Slow fashion promotes quality over quantity (Fletcher, 2007). 


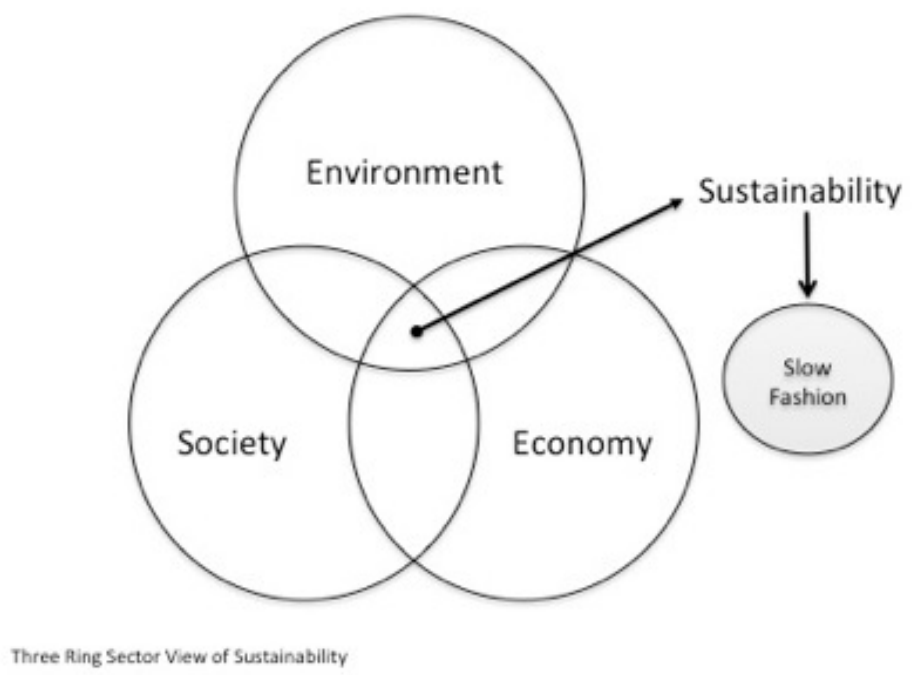

Figure 1 Source, Author. Three ring sector view of slow fashion

\subsubsection{Voluntary Initiative}

Any non-mandatory, rules based partnership or collaboration among multiple supply chain stakeholders aimed at improving the social, economic and environmental sustainability of commodity production and/or trade (Giovannucci et al., 2008). Examples include Better Cotton Initiative, Sustainable Apparel Coalition, GOTS, NICE and Fair trade. Existing voluntary initiatives (VI) will be discussed and examined in chapter 6 .

\subsubsection{Certification}

Certification is the process of verifying that an industry player is meeting the rigorous standards (throughout their supply chain) that will then enable them and/or their products to be labeled i.e. Fair trade or Organic. Certifications can be part of a voluntary initiative, but not all voluntary initiatives have certification schemes.

\subsubsection{Fashion vs. Apparel}

For the purpose of this study the term fashion, rather than apparel will be used when referring to the entire 'industry' surrounding the product cycle from design to consumption. The aim of this paper is to investigate the possibility of mainstreaming sustainable fashion for style and function. Therefore, for the purpose of this paper the term 'fashion' will be used as it refers to both style and function of a garment. 
In academic literature the terms fashion, garment and apparel industry are used interchangeably. All three terms refer to the clothing manufacturing industry and supply chain. However, the term fashion seems to insinuate the notion of curated design and intention behind the creation of a garment. Fashion represents the way clothing communicates our individuality within society (Fletcher 2008). Fashion is often thought of as frivolous or decadent with an emphasis on style. The fashion industry comes with an entire media and marketing team behind it. Fashion represents the aesthetic of dressing for more than function. In comparison, the term apparel is used when referring to basics and functional wear, it does not conjure images of style and glamour the way fashion does. 'Fashion can be defined as discarding of clothes that are fully functional for purely semiotic or symbolic reasons' (Koefoed and Skove updated in Gardettin \& Toress, 2013, p. 6).

\subsection{Conclusion}

The fashion industry presents considerable environmental and social impacts throughout its supply chain. The following chapters will address the impacts and the roles retailers can play as proxies for consumers by informing consumers through generating greater awareness of these impacts and providing sustainable alternatives. Chapter two, the literature review, outlines the negative environmental impacts and illustrates the improvements being made by the sustainable fashion industry. The literature review examines fair trade-type certification as a comparison for sustainable fashion. Chapter three outlines the methodology used throughout the paper, a mixed method approach including both quantitative and qualitative analysis. Chapter four provides a content analysis, analyzing the CSR reports of five major fashion retailers to demonstrate trends in sustainability reporting. Chapter five draws on lessons from the fair trade coffee industry, looking to apply lessons from fair trade type certification to the fashion industry. Chapter six examines the role retailers can play as proxies for consumers by highlighting two leaders in the sustainable fashion industry; Marks \& Spencer, a fast fashion brand and Patagonia, an outdoor apparel brand.

\section{Chapter 2}

\subsection{Introduction}

A review of the literature provides considerable evidence that there are significant negative environmental and social impacts in the making of textiles, from the manufacturing of garments through to the consumption and disposal by consumers. Increasingly there is recognition of the significance of the environmental and social impacts of the fashion industry by consumers through media coverage and NGO campaigns. Consumers, designers, academic institutions and retailers alike are beginning to place greater emphasis on the importance of sustainability in the fashion sector. The volume of voluntary 
initiatives and codes of conduct promoting a more sustainable fashion industry have been on the rise since the 1990s (Ashby, Hudson Smith \& Shand 2013). Some of these initiatives include, but are not limited to, the Clean Clothes Campaign, Better Cotton Initiative, Labour Behind the Label, Greenpeace Detox Campaign, EcoCert and the Ethical Trading Initiative (Goworek 2001, Ashby, Hudson Smith \& Shand 2013). Research demonstrates that in response to the growing awareness of the negative environmental and social impacts of the fashion industry, retailers and designers are taking part in these voluntary initiatives and adhering to their standards. However, while there exists a large number of voluntary initiatives directed at improving the negative environmental impacts of the fashion industry, there has yet to be a comprehensive voluntary initiative addressing both environmental and social issues covering the entire lifecycle of a garment that is user friendly to producer, consumer, designer and retailer alike. In order to accelerate sustainable fashion, the fashion industry needs to look at the entire lifecycle, from fiber harvesting to disposal, in order to promote a process that assesses the impacts generated across all aspects of the industry (Cataldi et al 2013). This paper will present the case that the fashion industry can draw lessons from the fair trade coffee movement that could lead to better inform their business practices and engage with consumers on a wider scale.

The increase in voluntary initiatives in consumable goods, specifically those centered on social issues like fair pay, have begun to garner increased consumer support. Literatures shows that fair trade-type certified coffee addresses both the environmental and social issues and presents a cohesive certification initiative. Fair trade offers better trading conditions for coffee farmers and engages in supporting producers and sustainable farming practices through education and training programs. Fair trade prohibits the use of child or forced labour, an issue the fashion industry faces. Globally, since 2000, fair trade purchases have increased $20 \%$ annually and in Canada fair trade products have increased by $85 \%$ from 2003-2007. In 2012, 430,000 metric tonnes of fair trade certified coffee were produced, making coffee the third largest producer of sustainably compliant coffee on the market (Potts et al., 2014). Since the fair trade Labeling Organization International (FLO) was created in 1997, the number of certified fair trade producers tripled by 2007 and sales have increased by $40 \%$ annually (Fair trade Labeling Organization International 2007). Literature illustrates that fair trade has moved to a more mainstreamed movement, taking a sizeable portion of the market place. Fair trade coffee demonstrates the success of an initiative with clear messaging and objectives from a consumer and retailer perspective. Coffee with fair trade-type certification led in market penetration, reaching $40 \%$ of global market share in 2013. Sustainable cotton saw a 55\% increase of production from 2012 to 2013 (Potts et 
al., 2014). Literature demonstrates that retailers played a role in in the rising popularity of fair trade coffee. Starbucks introduced Fair Trade Certified coffee to their consumers in 2000 and purchased 0.6 million pounds of fair trade coffee (Jaffee, 2012). Starbucks acted as a proxy for its consumers by acting on behalf of its consumers to provide environmentally and socially responsible options.

Since the 1992 Rio Earth Summit, stakeholders from all segments of the global economy have placed emphasis on improving sustainability standards. The Rio Summit called for greater attention to sustainable production and consumption. There now exist over 400 consumer facing eco-labels penetrating the market (Potts et al., 2014). These labels and voluntary initiatives have proven incremental in improving transparency across supply chains while promoting efficiency and consistency in their efforts to address issues of environmental and social concern (Potts et al., 2014). While there has been increase in consumer-facing labels and the production of 'standard compliant' products, production currently exceeds consumption and demand (SSI Review, 2014). While standards have done a relatively good job at strengthening the reliability of market claims through increased monitoring and have created new opportunities for nontraditional perspectives to enter the supply chain, special investment is needed in order for voluntary initiatives to adequately operate as tools to reduce poverty and reduce environmental impacts (Potts et al., 2014) and to promote greater consciousness of consumers through the private and public sector alike.

Additionally, academic awareness analyzing the environmental impacts of the fashion sector has increased over the past 10 years. Gardetti \& Torres (2013) published Sustainability in Fashion and Textiles: Values, Design, Production and Consumption an academic text compiling peer reviewed articles on the impacts of the fashion industry. A multitude of authors and organizations have analyzed the impact of the fashion industry including Allwood et al (2006), DEFRA (2011), Dickson et al (2009) and Portway \& Lewis (2012). In 2007, the WWF commissioned the study financed by Marks and Spencer Fashioning Sustainability: A Review of Sustainability Impacts of the Clothing Industry conducted by Draper, Murray and Weissbrod. Institutions are beginning to teach sustainability to their design students, and in 2011 the University in Berlin launched the first MA in Sustainable Fashion Design. Finally, industry leaders in sustainable fashion have published a number of books. Most notable, Sustainable Fashion and Textiles: Design Journeys by Kate Fletcher (2008), Future Fashion White Pages (a collection of sustainable fashion essays from industry professionals) by Leslie Hoffman (2008), To Die 
For: Is Fashion Wearing out the World? by Lucy Siegle (2011) and Overdressed: The Shockingly High Cost of Cheap Clothes (2012) by Elizabeth Cline.

While there is a rise in the awareness of the negative impacts of the fashion industry, they are only just recently being examined by scientists and therefore are not fully conveyed to policy makers and consumers, making the shift towards a more eco-conscious industry difficult. We are only just beginning to see academic institutions introduce sustainable fashion into the curriculum. Ryerson University in Toronto, Canada has a prominent fashion department and now offers classes in sustainable fashion, but sustainability is not part of the core curriculum. A study by Meyer (2001) demonstrates that consumers are not willing to purchase green apparel products due to the higher cost, reduced choice, aesthetic and functional disadvantages, lack of information, and uncertainty about actual benefit to the environment. Consumers often lack adequate information to make informed and eco conscious choices when purchasing clothing.

Pollution prevention measures are imperative for the fashion industry's continued growth. A growing awareness of the negative environmental impact of fashion is generating an increase in demand for sustainable fashion. However, research on the environmental impacts of the fashion industry remains in its infancy. In addition, a gap continues to exist between what consumers say they want and what they actually purchase. With the end product in mind, leaders in the textile industry should address the growing concern regarding fashion's detrimental environmental impacts (Gam, 2007). With the aid of organizations, activists and concerned industry leaders and consumers, there has been a growing effort to monitor fashion's environmental impact both in its production and consumption phases in order to create fashion with both planet and profit in mind.

The fashion industry has begun to take a look beyond the consumption of garments to assess the impact of consumer waste generated by the industry. Both the global apparel market and consumers' awareness of the positive effects of repurposing or refurbishing (recycling or up-cycling) apparel on reducing environmental impacts has increased in the market as the textile and apparel industries have demonstrated a substantial effort to increase the use of recycled materials. A handful of apparel industries have adopted McDonough and Braungart's (2002) 'Cradle to Cradle' model as a solution to eliminate many environmental problems. Cradle to Cradle looks beyond the closed loop system and will be addressed further in this research. In addition, the use of recycled polyester (rPET: recycled 
polyethylene terephthalate), for apparel items has been widely implemented by many leading apparel companies such as Nike, Under Armor, Patagonia and Columbia. Most commonly, rPET is used to make fleece garments.

Large fashion retailers and brands have begun to address sustainability issues themselves, most notably Patagonia with its use of rPET to make fleece garments, PUMA through its Environmental Profit and Loss Report (2010), H\&M through its partnership with the Better Cotton Initiative, LEVI's with its line of recycled denim and NIKE which launched the Making App (2013) which allows retailers and designers to compare the environmental impacts of fibers across sectors.

Despite these shifts and advances, the fashion industry remains one of the most environmentally and socially degrading industries (Siegle, 2011). With the exception of the mining and agricultural industries, few industries are as connected to the natural world as fashion. The fashion industry depends on water resources and crops such as cotton, yet is only just beginning to factor in the consequences of the industry on the natural environment, which include shrinking biodiversity and climate change (Siegle, 2011). In order for sustainability in the fashion industry to really take shape, it requires the use of collective learning mechanisms for stakeholders across the industry to create the necessary space needed to determine a collective vision around what a sustainable fashion industry looks like (Cavagnaro \& Curiel, 2012).

\subsection{Literature Review:}

\subsubsection{Introduction:}

Sustainable fashion is an emerging industry and academic field. The literature review will highlight the negative environmental impacts generated from the making of textiles and garments and from the consumption and disposal of fashion. The first section of the literature review will provide the background information highlighting the negative environmental impacts of the fashion industry. Fast fashion remains the prevailing force in terms of sales in the fashion industry; therefore, research will look to provide an understanding of the fast fashion landscape. Due to the breadth of textiles used in the fashion industry, research will focus on the impacts of producing cotton. Cotton represents the largest component of fiber used in the fashion industry, with conventional cotton creating significant impact on the natural environment. The literature will also highlight the lack of consumer awareness surround the negative impacts of the fast fashion industry. 
The second part of the literature review highlights the growing number of sustainable brands within the fashion industry to showcase the groundwork retailers, designers and NGOs alike have begun to do. In addition, key voluntary initiatives addressing the impacts of the fashion industry and the role they can play in shaping the future of the sustainable fashion industry will be addressed. The literature review will provide a history of the fair trade coffee movement. Research undertaken or this paper that assesses the key leaders in the sustainable fashion industry and examines successful voluntary initiatives in other sectors, like Fair trade coffee, will assist in the development of proposed strategies that will provide the framework to further address environmental concerns generated by the fashion industry.

\subsubsection{The Fast Fashion Industry}

Fast fashion represents the latest manifestation of the fashion industry, accentuating the negative environmental impacts generated by the industry through the creation of disposable fashion. Fashion is now produced at an ever-increasing rate. The consumption of fashion leads to an increase in water, energy, $\mathrm{CO} 2$ and waste generated by the industry. Over the past two decades the fashion industry has dramatically changed. 'The emergence of the 'fast fashion' business model has increased the introduction of trends leading to premature product replacement and fashion obsolescence; (Kozlowski, Bardecki \& Searcy, 2012) What used to be an industry with only Fall/Winter and Summer/Spring seasons has transformed into an industry with 52 micro-seasons (Siegle, 2011). Fast fashion is typically priced lower than high-end competitors and works on a model of high volume/low quality. Zara, the world's largest retailer receives two shipments a week and H\&M and Forever21 receives daily shipments of clothing.

Fast fashion promotes mass consumption of low quality goods. Fast fashion items are often made in factories in developing countires where environmental and social standards are not strictly upheld. The Centre for Environmental Health (2010) found that Forever21 and Wet Seal, two fast fashion brands, were selling purses and belts that were lead contaminated above legal amounts. The Centre for Environmental Health also found traces of pesticides, formaldehyde, flame-retardants and other known carcinogens on fast fashion clothing.

\subsubsection{Environmental Impacts of the fashion industry:}

Literature demonstrates that there are considerable negative environmental and social impacts 
generated through the making of textiles and apparel and in the consumption and disposal of garments. The environmental impacts of the fashion industry are felt across the entire supply chain and vary significantly depending on the type of fiber used. Cotton production requires significant water and chemical use generating toxins through pesticides and fertilizers. Whereas, synthetic fibers such as polyester and nylon release significant amounts of Green House Gases (GHG) through the use of fossil fuel (DEFRA, 2011). The use of petroleum-based polymer content textiles has increased in recent years due to their high mechanical and physical properties for functional applications and price (Huang \& Netravali, 2009). These materials use significant amounts of petroleum, a fossil fuel that is nonrenewable and in addition, a majority of those synthetic fibers are often blended or non-biodegradable making them difficult to recycle.

Textiles and their end products constitute the world's second largest industry, ranking only below food products. At least $10 \%$ of the world's productive energies are devoted to this activity and a huge segment of the global population earns its living and obtains its creative satisfaction from the same source (Unknown, 1972).

Cotton generates pollution throughout the production chain resulting in toxic wastewater, air pollution and solid waste. Much of the cotton production process involves the use of solvents in the wet processing. These solvents create pollution mainly in the form of emissions of volatile organic compounds (VOC) created through the dyeing and finishing processes (MIGA, 1996). Wastewater is a toxic byproduct of cotton processing created from the dyeing process and pesticide use during the agricultural phase. Air emissions generated throughout the production process include: dust particles, oil mists, acid vapors and odors (MIGA ,1996).

The negative environmental impacts of cotton production and processing, generating toxic waste water, air pollution, solid waste and the depletion of water resources in conjunction with the excessive use of toxic pesticides emphasizes the industry's need for preventative measures (Rehman \& Shafiq, 2000). Simply controlling the pollution is not an adequate alternative for the textile industry. Innovative preventative measures that seek to decrease the overall amount of pesticides and water during cotton processing and those that encourage training to increase cutting efficiency in factories will prove to be economically beneficial for companies and less intensive on the natural environment (Moore, 2004). 
The creation of 'fast fashion' has led to a decrease in product quality, sharply increasing postconsumer textile product waste, resulting in a great concern for waste management. In the US 16 million tons of textiles make their way to landfills each year (EPA, 2010). The Council for Textile Recycling estimates that 1.14 billion Kilograms of postconsumer textile waste (including anything made of fabric) is collected and diverted from directly entering landfills. However, this diversion represents only $4.55 \mathrm{~kg}$ for every person in the United States, or approximately $15 \%$ of all the clothing that is discarded. In the UK, the average consumer throws 30kg of clothing into landfills each year (Allwood et al., 2006).

According to the US Environmental Protection Agency (EPA), in 2010, 13 million tons of textile waste was generated, making up 5.3\% of total municipal solid waste. The EPA (2010) estimates that only $14 \%$ of all clothing and footwear are recovered for export or reprocessing, and the overall recovery rate for all textiles was $15 \%$ ( 2 million tons) in 2010. Of the recovered textiles in $2009,60 \%$ were exported abroad, often to underdeveloped countries like Haiti where the imported textile waste is not monitored and regulated. In 2009 the US exported approximately 1.4 billion pounds of used clothing (EPA, 2010) The environmental impacts of garments do not end with purchase by the consumer. Instead, their impact continues through the laundering process and discard at the end of life. The negative effects of clothing extend beyond the retail doors; major impacts of clothing are felt post-purchase through laundering and disposal of used garments. A 1993 study by Franklin and Associates found that the major environmental impact in the lifecycle of a polyester blouse was felt during the consumer phase (Lynn, 2010):

...as much as 82 per cent of energy use, 66 per cent of solid waste, over half of the emissions to air (for carbon dioxide) and large quantities of waterborne effluents ( 96 per cent if measured by Biological Oxygen Demand alone) are amassed during washing and drying (Lynn, 2010, p.1).

An additional challenge lies in the recycling of garments. Material blends have become popular fabric choices, as they are affordable and conventional. These hybrids are made of mixtures of technical nutrients and biological nutrients. For example, cotton-polyester blends are widely used for wrinkle-free shirts and pants. However, they are neither biodegradable nor recyclable after use, so they often end up in a landfill. In addition, apparel products are often constructed with mixtures of a few different materials including thread, buttons, zippers, trims, etc., which makes the garments difficult to disassemble for recycling and up-cycling. 
The social and environmental impacts of the fashion industry are felt on a global scale. From production to consumption, a single garment passes through many hands, traversing multiple countries, consuming natural resources and human labour, most often to the detriment of all (Cachon \& Swinney, 2011). Based on current research it appears Canada lacks strict regulations to monitor and uphold environmental and social protection laws specifically within the fashion industry. Due to the fashion industry's global reach, spanning many jurisdictions, regulations are difficult to implement, monitor and enforce (Gam, 2007). Strict voluntary initiatives that focus on raising designer and consumer awareness, thereby creating greater demand for eco fashion, could have greater potential to lead to reform within the fashion industry. The fashion industry can learn from the clear messaging and mainstreaming of Fair Trade marketing.

\subsubsection{Lack of Consumer Awareness on the Impacts of the Fashion Industry}

In the 1990s there was considerable negative attention on the fashion industry in large part due to the lack of social responsibility and accountability of factories located in developing countries (Kozlowski, Bardecki \& Searcy, 2012). The delocalized production in developing nations led in part to less stringent standards and regulations resulting in social impacts such as poor working conditions, low wages and health and safety issues, resulting in what are referred to as 'sweatshops' (Kozlowski, Bardecki \& Searcy, 2012). Media and NGO exposure of child labour and sweatshop factories in developing countries led to an increase in consumer engagement and perceived fear in retailers of widespread boycotts. This in turn led in part to a push for industry reform thus demanding brands respond and be held accountable for manufacturing throughout their supply chain. This shift in reform was set in motion by consumer demand, NGO campaigns and designer and retail cooperation. The industry began to introduce new codes of conduct and corporate social responsibility (CSR) standards to improve accountability (Abernathy et al., 1999; Klein 2000; Park \& Lennon, 2006; Shaw et al 2006; Kozlowski, Bardecki \& Searcy, 2012). The use of sweatshop and child labour has yet to be completely abolished, and the collapse of Rana Plaza in Bangladesh in 2013 demonstrates the issue still remains. However, the fashion industry as a whole has seen improvement in these areas through the adoption of sourcing policies and codes of conduct encouraging greater accountability throughout the supply chain. Most large retailers now implement third party factory monitoring and reporting. Just as the fashion industry sought to rectify the negative labour issues associated with production and manufacturing, the industry needs to begin to make reforms on their negative environmental impact. 
The consistency in green purchasing by industry leaders mentioned above demonstrates the demand of green products and services. However, while 'green purchasing' is on the rise, fast fashion continues to dominate sales. Consumers lack awareness on the negative health and environmental impacts of their clothing and therefore are hesitant to make the switch to purchasing sustainable fashion. Price and quality play a primary role in purchasing of eco garments. A study by Nakano (2001) found that consumers are not willing to pay over $10 \%$ more for sustainable goods, and that consumers associate purchasing 'green' products with saving money. Alternatively, a study by Bhaduri et al. (2011) found that there exists a lack of trust in business and retailer claims of sustainability and consumers do not want to fall victim to 'green washing' schemes. Furthermore, consumers find labeling unclear and inconsistent.

There exists a distinct contradiction between the fashion culture and sustainability. This inconsistency creates issues for the garment industry, and in order to move forward and address these issues in a critical manner, public awareness and understanding of the environmental impacts of the garment industry will play a strong role in helping the industry evolve into a more sustainable direction (Bhaduri \& Ha-Bookshire, 2011). There remains a distinct lack of communication to consumers generating confusion and a lack of trust on the perceived environmental impacts of the clothing industry. Thirdparty labeling and certification schemes remain unclear and inconsistent which only adds to consumer confusion and lack of trust.

The rise of sustainable fashion demonstrates a greater awareness among both retailers and consumers. However, it remains difficult to accurately predict the future of the sustainable fashion industry and market due to the fact that purchasing patterns are often in contradiction to self-professed values of consumers (Brown, 2011). There exists a distinct difference between what consumers claim they value and what they spend their money on. Consumers associate purchasing 'green' or 'sustainable' items with saving money. While two consumers may possess the same values and morals their purchasing patterns may differ. One consumer may purchase consciously to reflect their values and the other not. Interaction ritual chains attempt to decipher why it is that some consumers purchase ethically while others do not (Brown, 2011). Sustainability in the fashion sector is growing in awareness, but as sustainable fashion production and research remain in its infancy, the movement has yet to gain widespread momentum. 


\subsubsection{Sustainable Fashion a Growing Trend}

Sustainable fashion is a growing trend, with retailers and designers taking note and addressing both the environmental and social impacts of generated throughout their supply chains. The global sales of organic cotton have increased by $\$ 1$ billion in 2009, which amounts to a 35\% increase over 2008 (Organic Cotton Report, Textile Exchange 2013). Sales of cotton compliant with voluntary codes increased 50\% from 2012 to 2013 (SSI Review, 2014). This positive growth in demand for organic cotton is an indication that the size of the sustainable fashion market is expanding. Retailer supply chains are increasingly being evaluated by reporting agencies to determine their level of corporate social responsibility. The notable publication March to Sustainability 2011: Profiling Sustainability Plans of Leading Brands and Retailers for their Global Textile Supply Chains, illustrates the significance of the pressure put on retailers to produce responsibly.

While sustainable fashion was first met with criticism by consumers in the 1990s for offering poor quality products at high prices, over the past decade the industry has seen a significant change in terms of quality and style offered by sustainable fashion designers (Nakano, 2007). There currently are many voluntary initiatives addressing the impacts of the fashion industry; however, to date there exists no singular definition of 'eco', 'green' or 'sustainable' fashion. The suggestion made here is that because the precise meaning of 'sustainable fashion' is not clear, retailers have trouble promoting the notion of sustainable fashion to consumers.

Eco-fashion has been on the rise in terms of production, consumption and accessibility and continues to grow as a fashionable trend. Major retail conglomerates such as H\&M, Zara (Inditex) and Top Shop are beginning to introduce environmentally friendly alternatives, such as organic cotton products, in their retail stores. High fashion designers are creating and engaging with sustainable fashion. Vivian Westwood introduced an ecofriendly and ethical clothing line partnering with tailors in Kenya in 2011. In addition, sports apparel companies are taking a leading role in the promotion of sustainable fashion. Patagonia has been a longtime supporter of sustainable fashion, encouraging consumers to be conscious about their purchases. PUMA released an environmental profit/loss report outlining the environmental impacts of their production. The sustainable fashion movement has given rise to smaller, successful brands People Tree and Edun (Joergens, 2006). 
Sustainable purchases continue to grow across all sectors. Environmental data analysts at the Worldwatch Institute (2008) assessed capital flows in the green sector at $\$ 100$ billion, with investments into alternative energies ringing in at $\$ 66$ billion in 2007 and carbon trading transactions reaching \$30 billion in 2006. The phenomenon means more professionals, ranging from lawyers to securities brokers to engineers, are putting an environmental focus on their practices to help clients with compliance or identifying and creating business opportunities within this vast, emerging market. There is beginning to be a greater awareness of the impacts of the generated by the garment industry both on the people that create our garments but also on the impacts on the natural environment. Large companies are beginning to take note and implement sustainability initiatives into their branding.

The Multilateral Investment Guarantee Agency (MIGA, 1996) set straightforward standards and guidelines for the textiles industry to adopt preventative measures. These measures include (but are not limited to): the managing of batches in order to minimize end waste; avoiding non-degradable or low degradable solvents in washing; using pad batch-dyeing to save $80 \%$ of energy required and $90 \%$ of water consumption; reducing overall salt and dye usage; avoiding benzidine-based azo dyes and chlorine-based dyes or those containing heavy metals; reusing dye solution from dye baths; and reusing and recovering process chemicals (MIGA, 1996).

While these standards do exist, they have yet to be fully implemented and adopted throughout the garment sector. The global reach of the fashion industry makes monitoring of standards difficult as a single cotton garment's life cycle process can span many jurisdictions (Gam, 2007). Campaigns advocating against the use of azo-dyes have brought international attention to the negative human and environmental impact of these toxic dyes. Greenpeace spearheaded the Green Detox Challenge in 2011.Puma, Adidas, H\&M and Nike have signed on to the Greenpeace Detox Challenge - a campaign calling on large fashion companies to sign on to a 'toxic-free' future, working with all their international and domestic suppliers, to eliminate the release of toxic chemicals generated throughout their supply chain (Greenpeace Detox Campaign, 2011). The Greenpeace Detox campaign provides an example of consumer pressure leading to corporate reform.

Organizations such as the Better Cotton Initiative $(\mathrm{BCl})$ advocate for organic cotton partnering with large retailers like $\mathrm{H} \& \mathrm{M}(\mathrm{BCl}, 2010)$. $\mathrm{BCl}$ aims to inform consumers and to help create transparency in the production process of cotton. While $\mathrm{BCl}$ functions to support sustainable fashion through its promotion 
of organic cotton, it does not take a comprehensive and proactive approach in pollution prevention measures in the processing phase of cotton as it simply criticizes chemical use in the agricultural process, rather than undertaking an overall analysis. However, organizations like $\mathrm{BCl}$ do function to further engage retailers in their supply chain, which in turn can influence consumers in their fashion purchases, increasing demand for organic or sustainable apparel (Gam, 2007).

Scientists and engineers are beginning to develop standardized, reliable and relatively inexpensive testing and evaluation protocols for chemicals used on textiles (Moore, 2004). This functions to allow textile managers and their chemical suppliers to implement environmental decisions as part of purchasing processes. In addition, the development of environmental impact and evaluation methods allow cotton mill operators to include environmental impact assessment in their process development. Prior to these preventative developments, cost and mill performance were the only concern for determining purchasing decisions (Moore, 2004).

Fast fashion industry leaders such as H\&M have begun to incorporate sustainable fashion lines into their stores. H\&M launched the Conscious Exclusive in 150 of its retail stores in April 2014 in partnership with the sustainable-design think tank, Ever Manifesto (H\&M, 2014). The Conscious Exclusive collection provides sustainably made fashion forward clothing. H\&M is a global brand and therefore has the opportunity to inform and raise awareness regarding the impacts of the fashion industry to a global audience. The implementation of sustainably compliant fashion at large retail brands demonstrates the growth of the sustainable fashion industry.

As sustainable fashion continues to grow in popularity, there does not yet exist a voluntary initiative or certification or label that has generated widespread consumer acceptance and trust. Voluntary initiatives can play a pivotal role in influencing the fashion industry and providing consumers with a tool to inform their purchasing.

\subsubsection{Voluntary Initiatives}

Strict voluntary initiatives that focus on raising consumer awareness, thereby creating greater demand for eco fashion could have greater potential to lead to reform within the fashion industry. To do so, it appears that voluntary initiatives should include clear labeling of 'eco' products and designer input, combined with strict guidelines for company and designer standards. Voluntary initiatives and 
awareness campaigns by non-governmental organizations (NGOs) may be used to generate influence beyond the direct parties involved in order to influence both producers and consumers (Webb, 2004). Literature demonstrates that retailers can lead in voluntary initiatives and be positioned in a way to advocate on behalf of consumers and anticipate future demands or trends (Webb, 2004). As such, retailers have the unique ability to implement or demand producers uphold voluntary codes and thus may act as 'proxies' for consumers while anticipating future trends. It remains imperative that NGOs and retailers work together in order to create credibility for industry standards and codes (Webb, 2004).

The global context of the fashion industry makes regulating and monitoring difficult, as a single garment will most often traverse multiple jurisdictions before entering a retail store. The fast fashion industry allows for accessible and affordable clothing, but often at the cost of the environment and social standards. While, eco-conscious behaviour is on the rise, there appears to remain a lack of mainstream awareness regarding the negative environmental and social impacts of the fashion industry (Allwood et al. 2006). Consumers, retailers, suppliers and designers alike lack the proper tools and awareness to generate informed decisions on purchasing decisions. Information on 'sustainable' purchasing for the fashion industry remains fragmented. Therefore, it appears to be imperative that designers play an active role in the development of voluntary initiatives (Salerno-Kochan, 2008).

Webb (1999) articulates that voluntary initiatives can indeed have significant legal implications in the private sector, and can prove to work as a supplement to the regulatory system. Voluntary initiatives, which garnered popularity in the 1990s, are consent-based reform whereby companies, on their own accord, sign on to adhere to certain industry criteria and standards in exchange for benefits. Benefits can include greater consumer confidence as the company demonstrates good corporate citizenship or corporate social responsibility. When working in conjunction with strict, command and control regulation, voluntary initiatives can provide evidence, in the form of due diligence, for companies should they be charged with an environmental negligence. Adhering to voluntary initiatives may also involve less frequent inspections if a company is seen to abide by an accepted program (Webb, 1999).

In the Canadian context, policy goals of voluntary initiatives include the protection of consumers and consumer safety. Webb's (2004) arguments support the case that voluntary initiatives can also include the protection of the environment through sustainable practices balanced with the economic viability of a sustainable fashion industry within the Canadian context. However, specific criteria to evaluate and 
assess the effectiveness of the policy goals for the fashion industry are needed. Specific criteria should include increased consumer awareness, clear labeling, and designer and consumer input in the creation of sustainable fashion initiatives.

Voluntary initiatives, such as Fair trade, play a key role in a policy framework as they can function to strengthen state-based regulation. Due to the multi-jurisdictional aspect of the fashion industry, statebased regulation can be difficult to uphold and monitor throughout the entire supply chain. If volulntary initiatives include a requirement for greater transparency, designers and retailers are in a position to demonstrate that the garments they sell and manufacture comply with stipulated environmental criteria. A label like Fair trade has widespread recognition among consumers, retailers and producers allowing for greater trust in the label.

Voluntary initiatives can establish a systematic approach to structuring environmental, social and economic impacts of a product. Over the past two decades, voluntary initiatives have become very important in the food and forestry industry through organic and fair trade certifications and the creation of FSC. However, voluntary initiatives have been more difficult to implement for textiles and artisanal products due to the multi-jurisdictional aspect of the fashion industry as most garments are created in many different countries. Most voluntary initiatives address only one part of the fashion supply chain. A number of voluntary initiatives and labels exist specifically for the fashion industry including the Better Cotton Initiative (BCl), the Sustainable Apparel Coalition, MADE BY, Water<less, Organic, Eco Label, Cradle to Cradle Certification and NICE. Depending who you ask there are over 300 eco labels for the fashion industry. Despite this, there is an inconsistency among measurement, criteria and word usage used to identify sustainable fashion. The amount of VIs can lead to audit fatigue for retailers and does not create trust among consumers (Gam, 2007). Chapter 5 will further address existing VIs in the fashion industry and highlight lessons the sustainable fashion industry can apply from the fair trade coffee industry.

\subsubsection{Certification and Labels:}

Certification schemes are often an attempt to help create a more equitable or environmentally responsible response for industries. In the case of fashion, an industry that transcends borders and industries, regulation is difficult to implement, monitor and uphold. Therefore, voluntary initiatives, 
which can include certification, can offer a way for industry leaders and small retailers to perform due diligence and demonstrate to their consumers that they are working towards improving industry standards. The prevalence of certifications and labels has risen due to regulation in response to failed interventionist states to meet demand made by a globalized system (Garcia-Johnson \& Sasser, 2001).

Consumers rely on information given to them by certifications and labels to assist them in making decisions about the quality of intangible elements that they cannot verify for themselves, like environment and equity (Meyers, 2001). These certifications provide distinctive quality signs to create consumer recognition and market valorization. In essence these certifications and labels, such as Fair Trade, synthesize information, which allows consumers to reduce the time allocated to researching products (Renard, 2005). Labels create the distinction for the consumer. Therefore, represent power in the market. In order for a label to be successful it must gain consumer confidence in the truth it promotes (Renard, 2005). Certification schemes like Fair Trade use quality as symbolized by labels to form the basis of consumer recognition and market valorization. Labels must act on both sides as a sign of validation for consumers and an insurance of quality on the market side.

To create a successful certification scheme, signs must be clear, intelligible, and believable and carry unequivocal significance shared between all actors that integrate the supply chain (Renard, 2005). In the case of Fair trade coffee these actors include small producers and plantation workers, large landowners, processors, producers, brokers, importers, roaster-distributers, retailers and consumers (Waridel, 2002). Certifications require norms and standards to define their legitimacy and strict guidelines to control the use of the certification (Renard, 2005).

Labels require a public or private regulatory organization that generates legitimate criteria to guarantee products comply with the characteristics outlined. The Fair Trade Labeling Organization International (FLO) provides regulatory criteria for the Fair Trade certification. The FLO functions to create the control mechanisms to establish barriers to enter the market niche of Fair trade and creates economic cooperation between actors around quality (Bernard, 2005).

In order to garner greater awareness for sustainable fashion, it appears that voluntary initiatives should include clear labeling of 'eco' products and designer input, combined with strict guidelines for company and designer standards. Voluntary initiatives and awareness campaigns by NGOs may be used to 
generate influence beyond the direct parties involved in order to influence both producers and consumers (Webb, 2004). Scholars have noted environmental and social, thereby acting as "proxies" for environmentally and socially conscious consumers This "consumer proxy" capability of retailerscan be useful in driving environmental and social change throughout the supply chain, working with other actors such as NGOs. The role of retailers as proxies is explored in greater detail in Chapter Six.The global context of the fast fashion industry makes regulating and monitoring difficult. On a large scale there still exists a lack of understanding and consensus on what sustainable fashion really is. Without clear messaging from the fashion industry, consumers are left struggling to understand the complexities of sustainable fashion. Therefore, it appears to be imperative that retailers play an active role in the development of voluntary initiatives (Salerno-Kochan, 2008).

\subsubsection{Fair Trade Coffee:}

Fair trade functions as a critique to conventional trade practices rooted in a history of inequalities. It offers an effort to create more equitable commodity networks that link consumers in the Global North with marginalized producers in the Global South. The Fair Trade model, and other fair trade type certification models, offers consumers in the North options that demonstrate greater emphasis on sustainable and ethical production methods and emphasize responsible consumption through advocacy campaigns. In the Global South, Fair trade seeks to offer producers better prices, market access, more stable market links and resources for sustainable and ethical projects (Raynolds, 2008).

The Fair trade Labeling Organization (FLO) is responsible for certifying many agricultural products and artisanal goods including coffee and cotton. Based in Bonn, Germany, FLO first functioned as an umbrella group to 20 labeling initiatives in 21 countries. Coffee is the world's second most valuable traded commodity, second only to oil with an estimated 2 billion cups sold each day (Raynolds, 2008).

Fair trade, concerned with the conditions of production in the formal sector of mainstreamed commercial companies, focuses on the conditions of specific groups of producers. Fair Trade looks at cooperatives of small producers or plantations that meet the registration criteria. Fair Trade helps these cooperatives gain market access and promises a minimum price guarantee. It seeks to build a network of exchange and to establish a relationship between consumers in the North and producers in the South 
that transcends conventional commercial transaction by providing producers with tools of empowerment (Taylor, 2004).

Similar to the sustainable fashion movement, no singular definition of fair trade coffee exists; however, each fair trade type of certification seeks to address environmental and ethical issues across the supply chain and involves a form of third party monitoring to assure conformity to consumers. Each type of initiative comes with a consumer-facing label. Research will highlight the fair trade movement through addressing the following initiatives: Fair Trade International (FLO), Fair Trade USA, UTZ, 4C Association, Starbuck's Fairly Traded Coffee and Rainforest Alliance with specific focus on the FLO and Fair Trade USA standards.

\subsubsection{History of Fair Trade:}

Prior to Fair Trade, the coffee industry was subject to the International Coffee Agreement established in 1962. The precursor of the ICA was the Inter-American Coffee Agreement (IACA) established during WWII. With coffee prices decreasing, the US feared that Latin American countries would be driven towards Nazi or Communist sympathies. In 1940 the US restricted their import quotas and Latin American countries restricted their production. The restrictions allowed coffee prices to increase to nearly double in 1941 (over 1940). The International Coffee Agreement (ICA) is an international commodity agreement between coffee producing countries and coffee consuming countries. The aim of the ICA was to create and maintain quotas for the export of coffee to keep coffee prices stable and high in the market. The ICA represents all producing countries and most consuming countries. As of 2014, the ICA has 45 members consisting of 39 exporting members and 6 importing nations and 1 importing community (the EU represents all states as one member).

The agreement set limits on trade of coffee to avoid excess supply and a drop in price. This agreement was set up to establish a way to protect farmers and producers. In 1976 the agreement was renegotiated and price quotas were suspended. In 1983 the agreement was once again redrawn but this time with more strict import and export regulations. In 1989 the 1983 agreement was extended but without quotas because they could not be determined. From 1990 to 1992 the coffee industry fell into a crisis. With no quotas in place coffee prices fell to an all-time low. The market was flooded with coffee at low cost with supply exceeding demand. Fair Trade Certification set to artificially increase coffee prices to ensure profit to growers. 
In the 1940s and 1950s, NGOs and religious organizations, such as Ten Thousand Villages, sought to create more equitable supply chains for producers. This movement was first geared towards the creators of handicrafts. In the 1960s, as the International Coffee Agreement was established, the fair trade movement began to take shape. With its development came the criticism that industrialized countries and multinational corporations were simply looking for another way to use their power for further enrichment to the detriment of poor countries and producers.

As the movement and needs continues to grow, fair trade attempts to address some key problems in the global marketplace by addressing the producers', consumers, shareholders and retailers by representing a new way to do business. Fair Trade highlights inequalities across the supply chain by providing a holistic view to address market failures at their source, while still understanding the need for profitability. Consumers are beginning to demand greater transparency and increased fairness throughout the supply chain. Large corporations are beginning to take note, and Corporate Social Responsibility (CSR) has raised a boardroom level topic for discussion to address the consumer demands (Nicholls \& Opal, 2005).

Fair trade originated as a response to poverty post WWII. Flooded coffee markets with prices at all-time low due to lack of quotas led to Fair Trade Coffee movement. Certification aimed to artificially raise coffee prices to ensure profit to growers. Certification was introduced in 1988 and was launched in the Netherlands and throughout Europe. It wasn't until 1997 that the Fair Trade Labeling Organization International (FLO) was formed as the combination of the Fair Trade Foundation, TransFair USA and Tattvisemarkt.

Fair Trade emerged in the postwar period with two distinct streams; liberal development groups and religious charities such as Oxfam in the US and SERV in the UK, focusing on creating markets for handicrafts made by impoverished people though networks and 'world shops'. The other made up of more radical solidarity activists and NGOs mobilized around supporting grassroots movements in the third world (Renard 1999). Slowly the two sides came together in the 1960s and 1970s, but it was not until the 1980s that the current form of Fair Trade began to emerge. In 1989 the ICA collapsed, in part due to US commercial and foreign policy and coffee prices plummeted. 
In 1988 Solidaridad, a Dutch NGO, partnered with UCIRI Indigenous coffee cooperative in Uaxaca, Mexico with the goal to create a larger market for UCIRI coffee. Solidaridad created the label Max Havelaar, a label that could be applied to any brand that upheld their standards of fairness (Jaffee, 2012). These standards included fair wages for smallholders, repayment or credit advanced to farmers before harvest, additional premium paid to be used for community development projects, and long term trading arrangements with democratic producer cooperatives and associations. The Max Havelaar label was soon used by other alternative trade organizations and small roasters expanding beyond coffee to include other export crops such as cotton, bananas and tea (Jaeffee, 2012).

The structure was fairly simple: national licensing initiatives in each consumer country certified producer organizations to sell fair trade products, and licensed firms that met fair trade criteria to use the seal on the products they purchased from those organized farmers (Jaeffee, 2012, p. 103).

In 1997, following the success of the Max Havelaar label, the FLO formed in Bonn, Germany as a result of the rapidly growing European licensing initiatives. The following year TransFair USA was created. Originally independent of FLO and housed at the Institute for Agriculture and Trade Police, a Minneapolis Think Tank, TransFair USA became independent and in 1999 joined the FLO to adopt the mainstreaming strategy aimed to increase fair trade sales through conventional retail methods.

In 2010, TransFair USA changed to Fair Trade USA and FLO to Fair Trade International. Fair Trade USA and Fair Trade International differed over their criteria, with FLO requiring membership and representation from trade unions and development NGOs. A point of serious contention rose when Fair Trade USA began to license to companies in the US to sell Fair Trade products, most notably Starbucks (Jaffee, 2012).

While no universal definition of Fair Trade exists (similar to no universal definition of sustainable fashion), there exists a common consensus that Fair Trade is to act on behalf of the interest and rights of the producer. Both FLO (Fair Trade Labeling Organization International) and Fair Trade USA agree that their mission is to "use a market-based approach that empowers farmers to get a fair price for their harvest, helps workers create safe working conditions, provides a decent living wage, and guarantees the right to organize" (TransFairUSA, 2014). 
It is important to note that fair trade is not the only mechanism used to help regulate the coffee industry. Fair trade functions as one of many tools to provide market access for small producers in the Global South. Fair trade functions on a larger scale having attracted large corporate partners at the retail end. Smaller scale programs and tools, such as Direct Trade, can be efficient, but have yet to be integrated in a large and systemic way.

\subsubsection{Success of the Fair trade Movement:}

Fair trade coffee was sold in the US beginning in 1998. Fair trade originated as a response to poverty post WWII, launched in the Netherlands and as a social movement that gained momentum, Fair Trade officially became a certification in 1988. The purpose of the Fair Trade movement is to empower producers through fairer trade, which can lead to improvement in workers social and economic wellbeing and towards greater environmental sustainability. Fair Trade has become one of the most widely recognized certifications on the market. It is the most widely recognized certification mark in the UK, 6 out of 10 consumers have seen the label and of those, $89 \%$ claim they trust the FAIRTRADE mark (fairtrade.org, 2014).

In 2012 there were 1149 fair trade producer organizations worldwide with over 1.3 million farmers and workers in 70 countries, a 16\% increase over 2011 (FLO, 2013). Producers hold 50\% of the decision making power in fair trade and an estimated $€ 80$ million in Fair Trade premiums was paid to producers in 2012 (FLO, 2013). In 2012, Fair Trade America joined the FLO standard signing on major companies who now use the international trademark including Ben \& Jerry's, Divine Chocolate and Wholesome Sweeteners (FLO, 2013). Coffee was one of the first products to carry the certification in 1988 in Europe with production and consumption of Fair trade coffee growing each year (Jaeffee, 2012).

Fair trade coffee has been chosen for the comparison in this paper, as it was the first fair trade commodity. The system has grown to include teas, sugar, bananas and flowers among others. However, coffee remains the most prevalent in sales and volume (Jaeffee, 2012, p. 95). The mainstreamed fair trade movement is the combination of a coalition of activists, retailers, traders, producer organizations, conscious consumers, NGOs, and certifiers in over 70 countries. What began as a movement functioning outside of the capitalist model with a commitment to guarantee minimum price to producers to improve the livelihoods of farmers and artisans, now functions within the capitalist model attempting to 
create more equitable capitalist structures for small farmers (Jaffee, 2012). Fair trade provides an allencompassing voluntary initiative, addressing both social and environmental standards. As a consumerfacing label it has led in part to a greater awareness among consumers on the benefits of fair trade type certifications. Both large and small retailers played a large part in the success of the movement, playing a significant role as proxy for consumers in the rising popularity of fair trade coffee. Smaller retailers were at the forefront of the fair trade coffee movement, with larger retailers like Starbucks entering the fair trade market in 2000 (Jaffee, 2012).

According to Fairtrade.org, fair trade sales continue to grow each year. Excluding the USA, average sales of fair trade goods increased by over 20\% from 2011 to 2012. In addition, consumers spent 4.8 billion euros on Fair Trade products in 2012. Large retailers Nespresso, Ben \& Jerry's and Maltesers in addition to Nestle made major new commitments to fair trade in 2012. New countries, importers and distributers continue to become incorporated into the initiative. In addition, the sale of fair trade products has now begun to transcend to the Global South as they became available for purchase in both India and Kenya in 2012.

In response to the rapidly growing market of fair trade goods, addressing fair trade issues is now a part of the agenda for most major retailers in Europe, including Monoprix, Tesco, Migros and Carrefour (Nicholls \& Opal, 2004). Fair Trade is now the subject of hundreds of global media stories each year and is now taught as a formal part of academic disciplines including, business ethics, marketing, business development, buying and retail operations and international development (Nicholls \& Opal, 2004). Large organizations like the United Nations are beginning to take note of Fair Trade and recognize the model as a new model of trade as development agencies seek to move away from aid work towards trade (Nicholls \& Opal, 2004).

In Canada, municipalities are beginning to take note of the importance of Fair trade by adopting the idea of the 'Fair Trade Town' first used in England in 1999. The Fair trade Town promotes Fair trade as part of community effort through local business, town council and private citizen interest (Fairtrade.ca). In 2007 Wolfville, Nova Scotia became Canada's first Fair trade Town. Since 1999, 18 other towns have earned that designation including Toronto, Vancouver and Edmonton and an additional 23 towns have active campaigns in the works (Fairtrade.ca). There are now more than 1,300 Fair Trade towns in over 20 countries with consumers spending €4.8 billion on Fair Trade products in 2012 (FLO, 2013). 


\subsubsection{Conclusion}

Literature demonstrates that there are considerable negative environmental and social impacts felt throughout the fashion supply chain, in the production of textiles, the manufacturing of garments and in the consumer and disposal phase. Literature clearly illustrates that the fashion model is the latest manifestation of the fashion industry and is further increasing the environmental impacts of the fashion industry. Sustainable fashion is an emerging industry and academic field. While just an emerging academic field, researchers and environmentalists are now placing more emphasis on investigating the entire lifecycle of garments and addressing areas of concern (Kozlowski, Bardecki \& Searcy, 2012). In contradiction to the fast fashion industry, sustainable fashion is gaining in popularity and shows signs of being more than a passing fashion trend. While there exists no law so far that has been able to address the negative impacts associated with fashion, there are growing numbers of voluntary initiatives that address the specific negative environmental and social impacts of fashion. Literature demonstrates that some major brands and retailers are now implementing corporate social responsibility standards (CSR) throughout their supply chains, with a heavy emphasis on environmental sustainability. Chapter 4 will highlight five leading sustainable retailers and their environmental commitments and targets.

While there exist many VI used throughout the fashion industry, there has yet to be one comprehensive initiative and/or labeling scheme that addresses the entire lifecycle of a garment and generates consumer confidence. This lack of a cohesive VI makes it difficult for consumers to find confidence in sustainability claims of brands. Fair trade type certification schemes used in the coffee industry have provided this 'all in one' cohesive type certification and offer a pivotal point for consumers, producers and retailers alike to address both the environmental and social concerns of the coffee industry. Fair trade has become accepted as 'mainstreamed' in the consumer marketplace, with consumers and retailers alike purchasing fair trade alternatives over others. Fair trade type certification schemes can aid in providing a framework to develop strategies to further address environmental issues created by the fast fashion industry. Literature demonstrates the role retailers can play as proxies for consumers, by doing the research for consumers and acting on behalf of environmentally and socially responsible consumers. Chapter 5 will draw lessons from fair trade type coffee certification for the fashion industry and Chapter 6 will build a business case for sustainable fashion by highlighting leading sustainable designers and retailers. 


\section{Chapter 3 Methodology}

\subsection{Introduction}

Research methods will include a mixed method approach. Developed in 1959, the mixed-method approach has been used by researchers to collect and analyses both quantitative and qualitative data (Creswell, 2003). Research objectives are to determine trends in sustainable reporting of major fashion retailers, identify substantive developments in sustainable fashion, the emerging challenges and issues impacting sustainability, outline the role retailers and voluntary initiatives can play in addressing sustainability, and to draw lessons from the fair trade coffee movement that the fashion industry can adopt. This research will employ both quantitative and qualitative methodologies to address research objectives of assessing the feasibility of incorporating sustainability standards into the fashion industry by creating a business case for sustainability. Research will encompass a variety of social science tools including report and document analysis, word content analysis, comparative analysis and lesson drawing.

Methodology one, the literature review in chapter 2 illustrated the environmental impacts created by the fashion industry and the growing awareness of these impacts. Methodology two, content analysis using Nvivo software, will highlight the latest trends in sustainability reporting in the fashion sector through word content analysis. Through word content analysis, research aims to determine what sustainable practices retailers are reporting on and to track trends, if any, through reporting practices by major retailers. Methodology three, lesson drawing, (discussed further below) aims to fair trade type certification schemes for lessons that can be applied to the sustainable fashion market. Research is looking to find parallels between fair trade type certification for coffee and sustainable certification for fashion, particularly focusing on cotton. Methodology four, engages in a critical analysis of current organizations, initiatives, retailers and designers engaging with and promoting sustainable fashion to demonstrate the growing business case for sustainability. Research will highlight the key role retailers can play in addressing sustainability issues by highlighting key retailers that have made their sustainability part of their core business practices. Figure 3 highlights the details pertaining to each stage of methodology, which will be explained in the following sections. 


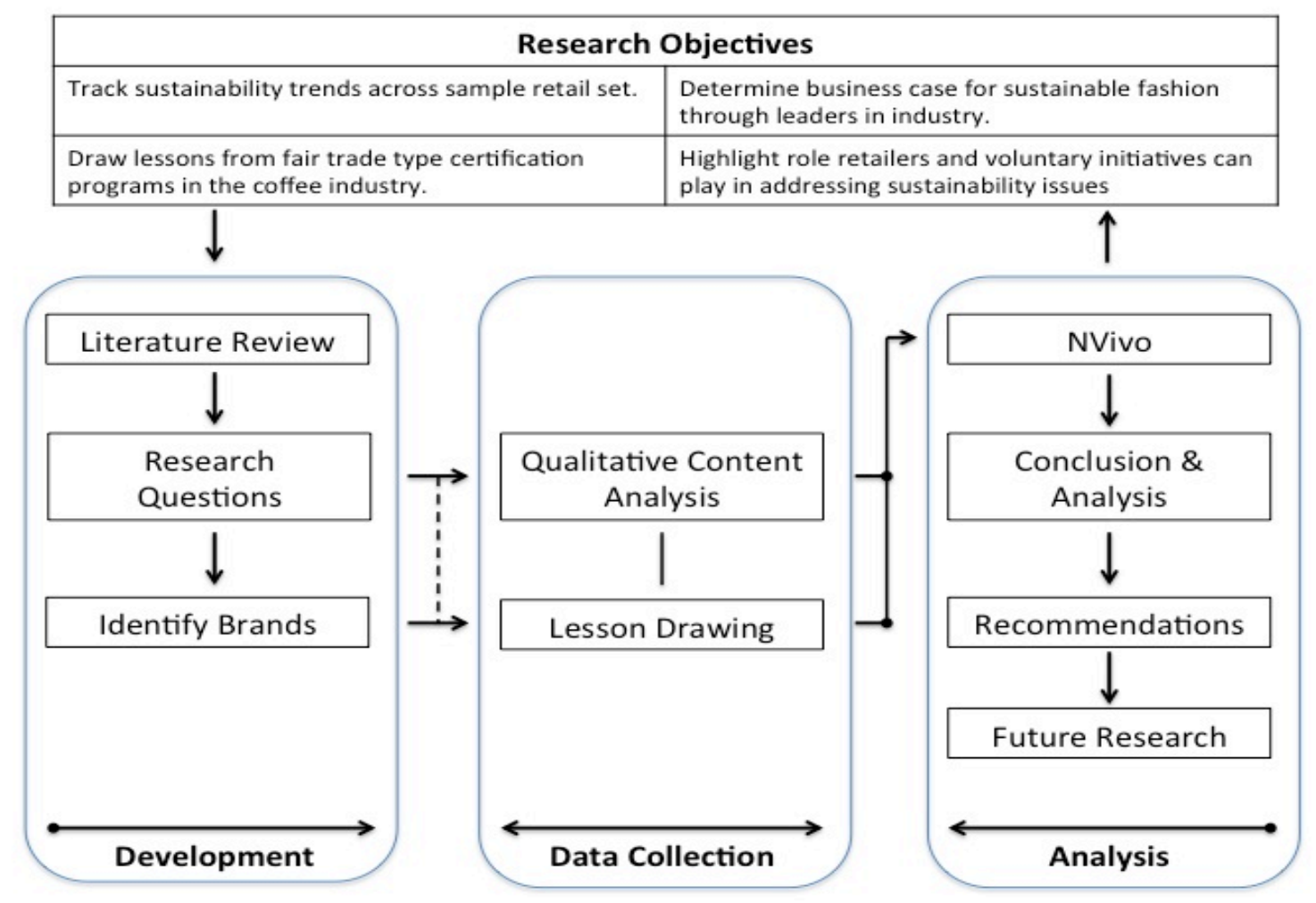

Figure 2 Source, Author. Research process

\subsection{Planning Stage}

\subsubsection{Identifying Brands}

Given the research's focus on sustainable fashion brands, the sample retail population draws on the largest retailers in the fast fashion and coffee industry leading in sustainability practices between the reporting periods of 2009-2013. As units of analysis, the research first sought to identify these key retailers in both the fashion and coffee industry.

The sample population of fashion and coffee retail brands was pulled from Maclean's top 50 Socially Responsible Companies in Canada: 2014 list, a leading industry report. The report highlighted five (5) leading fashion retail firms and two (2) leading coffee retail brands on the basis of their performance across a wide range of environmental, social and governance (ESG) indicators tracked by Sustainalytics. The fashion firms include Adidas, Gildan, H\&M, Inditex and Nike used as units of analysis to compare each firm's CSR strategy. Each company demonstrated strong public disclosure and performance in the areas of environmental initiatives, supply chain management and impact on local communities. Sustainalytics' research approach compares companies within a given peer group and includes thorough 
examination of company reports and documents, government sources, media sources and online databases.

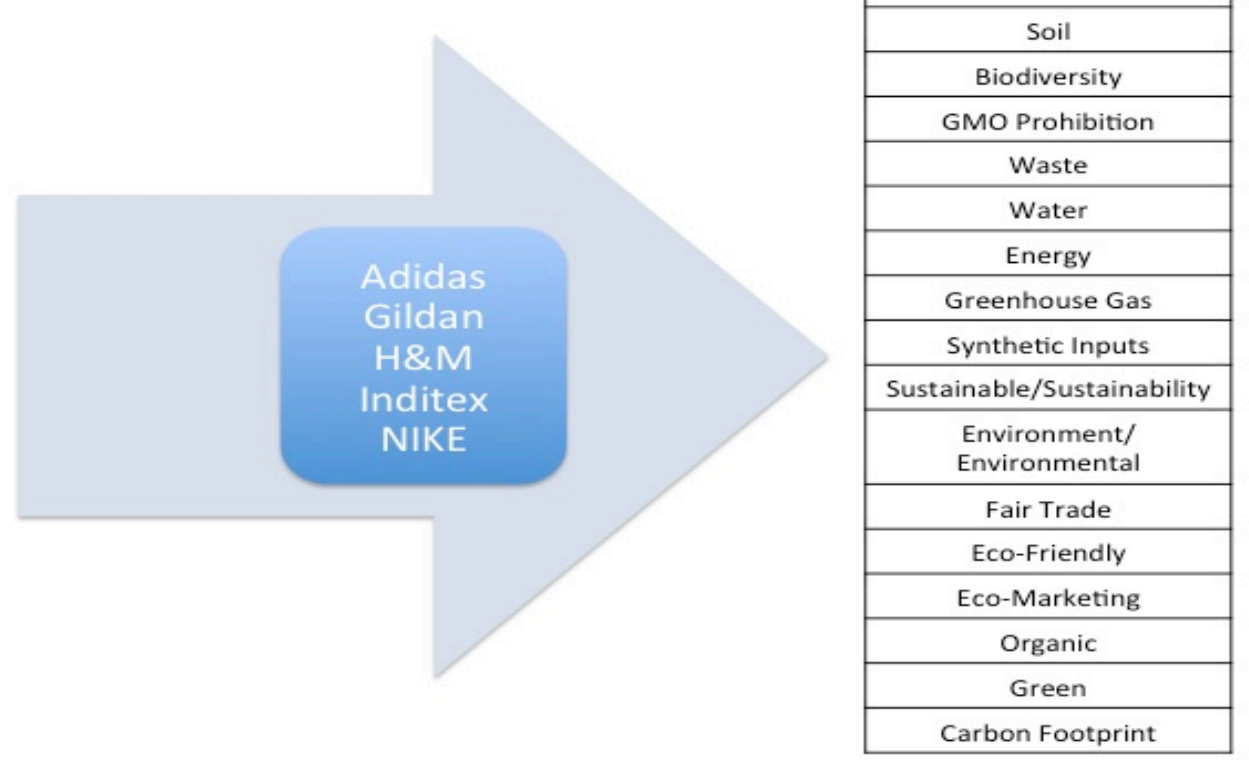

Figure 3 Source, Author. Sample Retail Brand Selection and word selection for content analysis ${ }^{\dagger}$.

\subsubsection{Identifying Key Words}

Once the fashion and coffee retail brands were identified, their annual Corporate Social Responsibility (CSR) reports, available through their websites, from 2009-2013 were collected. These CSR annual reports were analyzed to track sustainability trends. Trends were determined by identifying key sustainable words throughout each report.

Research pulled key words from Sustainability in Retailing-a Summative Content Analysis (Wiese et al 2010), a research paper analyzing past and current sustainability developments focusing on the role of retailers in supply chains. Weise et al (2010) used a summative content analysis to determine research objectives in scientific literature relevant to supply chains, with a specific focus on sustainability considerations in the retail sector. Weise et al (2010) identify retailers as playing a major role in supply chains as they act as the intermediary between consumer and producer. Retailers hold significant

\footnotetext{
'The term 'GMO prohibition' was listed in the Weise et al (2010) paper. The search yielded no results through NVivo word search.
} 
power to influence and engage in environmental supply chain management. Weise et al (2010) tracked the frequency of sustainability considerations in scientific literature in the retail sector between 19812010. The authors thoroughly analyzed the content of academic research papers in the retail sector and acknowledged that sustainable retail research is in its infancy with a promising path in its future. Weise et al (2010) discovered that as academic research is in its infancy it is currently impossible to make general statements about sustainability issues in retail (p.327). Weise et al (2010) analyzed only peer reviewed, academic literature, and a thorough examination of NGO reports and retail CSR reports will help provide a more holistic understanding of sustainability in the retail sector.

In order to supplement the research from Weise et al (2010) research pulled words from the State of Sustainability Initiatives (SSI) 2014 report. Launched in 2008, SSI releases leading industry reviews through a partnership between the International Institute for Environment and Development (IIED) and Aidenvironment. The SSI Review is an independent evidence-based report on the characteristics, performance and market trends related to sustainability initiatives. The SSI Review aims to provide supply chain decision-makers-including procurement agents, investment advisors, CEOs, policy-makers, sustainability initiatives and NGOs-with high-level data and analysis needed to navigate the increasingly complex field of sustainability standards.

The SSI project looks to enhance the global understanding about the role of market-based voluntary sustainability standards, (VSS) including labels and certifications, to promote sustainable development. SSI outlines three (3) main project activities to achieve review objectives:

1) Documenting the market trends and developments of the VSS sector through a regular series of "SSI Reviews"

2) Providing a regular reporting service on major VSS events

3) Facilitating thematic discussions on the relationship between VSS and key sustainable development issues.

While there currently exist more than 400 consumer-facing eco labels across the globe, the SSI 2014 Review analyzed sixteen (16) of the most important standards and initiatives, four (4) in the coffee sector and two (2) in the cotton sector. These sixteen initiatives currently certify or verify US\$31.6 billion, accounting for an important share in the global market in the agriculture, forestry and biofuels sector (SSI Review 2014). SSI chose initiatives with a global presence that are operational in one or more of the following commodities: bananas, biofuels, cocoa coffee, cotton, forestry, palm oil, soy, 
sugar or tea. Research will address initiatives targeting supply chains in the coffee and the cotton sector.

\subsection{Data Collection Stage}

\subsubsection{Qualitative Content Analysis}

Research used a qualitative content analysis as the scientific tool to approach research objectives. Qualitative content analysis is used to interpret meaning from the content of written communication, for the purpose of this paper content is interpreted from retailer CSR reports. Qualitative content analysis shows three approaches to interpret data; conventional, directed or summative. Research uses the directed approach, starting with relevant research findings to guide initial codes. Krippendorff (1980) identifies the following six questions to be addressed in the initial process of conducting qualitative content analysis; Which data is analyzed; How are they defined; What is the population from which they are drawn; What is the context relative to which the data are analyzed; What are the boundaries of analysis; and what is the target of inferences?

\section{1: Which Data Are Analyzed?}

Research analyses CSR reports published by retail fashion and coffee brands. To ensure consistency, research will focus on reports published between 2009 and 2013. To adequately answer research questions, data analysis focuses on identifying the following categories:

Market Overview: Research assessed the overall trends throughout each CSR report as they relate to sustainability and voluntary initiatives. The data will be compared against overall VI trends as published by the 2014 SSI review, to provide a holistic overview of VSS retailing trends.

Corporate Social Responsibility (CSR): Definitions of CSR across the fashion and coffee sector, mission statements and reporting measures of each retailer are identified. This section will assess the corporate culture and commitment to sustainability within the fashion retail sector.

Leading CSR Goals: Key CSR objectives by retailers, their goals and the reason they have been chosen are highlighted. 
Voluntary Initiatives/Certification Schemes: Analysis tracks the implementation Vls by each of the sample retailers.

\section{How Are They Defined?}

Retailers CSR performance is analyzed through their publically available online CSR reports and documents. Analysis focuses on CSR reports published between 2010 and 2014 for the reporting periods of 2009, 2010, 2011, 2012 and 2013 to provide a holistic landscape of trends as they have developed over the past five (5) years.

\section{What Is the Population From Which They Are Drawn?}

The population from which the retailers were chosen consists of retailers with significant brand presence or market capitalization in Canada. Retailers were chosen from Maclean's 2014 Top 50 Socially Responsible Companies. The sample population includes both fashion and coffee retailers.

4. What is the Context Relative to Which the Data Are Analyzed?

As referenced in chapter one, the research objective is to define key sustainability trends in the fashion retail industry to determine the feasibility of mainstreaming a VSS across the fashion industry. The goal of research is to provide an overview of the CSR landscape in the fashion retailing industry to highlight the role retailers and voluntary initiatives can play in addressing sustainability issues in the fashion industry by looking to lessons learned from the fair trade coffee movement. In addition, research will highlight the latest developments in sustainability in the fashion sector by showcasing the progress made in the retail sector.

5. What Are the Boundaries of the Analysis?

Analysis focuses on retailers with a presence in the Canadian market. Due to the wide range of fabrics used in the fashion industry, research focuses primarily on the production of sustainable cotton and initiatives addressing cotton production.

A second boundary is that each retailer needs to have made publically available their commitment to CSR objectives between the 2009 and 2013 reporting periods.

6. What is the Target of Inferences? 
Krippendorf (1980) defines inference as a deduction or conclusion drawn from facts, therefore, target inferences in the given research framework are the conclusions drawn from the trends analyzed in the identified data sets. The primary objective of this research was to define key sustainability trends in the fashion retail industry to determine the feasibility of mainstreaming a VSS across the fashion industry. To adequately address the primary objective, four (4) sub-questions were identified in chapter 1 that guided the development of data collection and analysis.

Each published CSR report from both the fashion and coffee retail brands was analyzed using NVivo qualitative research software. Research highlighted how each retailer defined sustainability, tracked trends in sustainability reporting and highlighted key sustainability words in CSR reports using NVivo to find commonalities throughout each published report.

\subsection{Lesson Drawing: Fair trade Coffee and Cotton}

Lesson drawing is most often used as public policy tool, often part of a contested political process. Lesson drawing is often used to emulate governmental programs that worked in one jurisdiction in another jurisdiction. Lesson drawing is often used in public policy literature to focus on public policy actors who look to another jurisdiction to see what policies may be adopted in their jurisdiction.

While lesson drawing is often a public policy tool used in politics, this research will use it as a starting point to draw lessons that the fashion industry can adopt from the fair trade coffee industry. In order to draw lessons and conclusions, research will use the fashion industry and the coffee industry as units of analysis. Research will look at the strengths and the weaknesses of the fair trade movement in the coffee sector to see how these lessons can be applied to the fashion industry, specifically focusing on the use of cotton. Rose (1991) states that lesson drawing answers the following question: Under what circumstances and to what extent can a program that is effective in one place transfer to another? The process must begin with scanning programs that are effective in one area and conclude upon evaluation of the outcome of a program being implemented to a new sector in the future. Rose (1991) defines lesson-drawing as a research method that can be carried out by searching across time and/or across space. Research will look to written materials on and history of fair trade-type certification to determine if the fashion industry can adopt elements of fair trade-type certification. 
Rose (1991) defines the following as the steps to lesson-drawing. Scanning programs elsewhere: this first step seeks information about programs by public agencies that have addressed similar problems allowing the researcher to gain fresh ideas relevant to a problem that is not adequately being handled across time and/or space. For the purpose of this research, lesson drawing is used less empirically and encompasses insights concerning governance by both public sector and private sector actors involved; instead, fair trade documents will be analyzed by the researcher. The researcher will draw lessons from written materials as to what can be recommended by private sector actors to in the future. The fast fashion industry faces the problem of a lack of consumer engagement and awareness of environmental and social impacts of manufacturing. Coffee faced a similar problem, with the introduction of fair trade type certification consumers are more aware and conscious of their coffee purchases. Research chose to highlight Fair trade as the working program to draw lessons from. The fast fashion and coffee industries share many similarities, which will be addressed further in the analysis stage.

Creating a new program: Lesson drawings draws on empirical evidence from one program to adopt for another. Rose (1991, p. 22) defines 5 Alternative Ways of Drawing a Lesson

1. Copying. Adoption more or less intact of a programme already in effect in another jurisdiction.

2. Emulation. Adoption, with adjustment for different circumstances, of a programme already in effect in another jurisdiction.

3. Hybridization. Combine elements of programmes from two different places.

4. Synthesis. Combine familiar elements from programmes in effect in three or more different places

5. Inspiration. Programmes elsewhere used as intellectual stimulus for developing a novel programme without an analogue elsewhere.

Research will use emulation as the alternative way to draw lessons from the fair trade coffee sector to the fashion industry focusing on the production of cotton. Rose (1991) states that emulation accepts that a program elsewhere provides a standard for designing a program at home. Emulation can function as a tool to generate innovation and to improve upon an existing model. Research looks to the fair trade coffee sector to adopt some best practices, taking into account the complexity of the fashion industry. 


\subsection{Building a Case for Sustainability:}

3.5.1 Role of Designers and Retailers and the case for sustainable fashion

Research chose leaders in the sustainable fashion retail sector to highlight key initiatives taking place in the sector. A small selection of designers and retailers with integrated sustainability standards were chosen to highlight the growing trend among retailers and designers, highlighting the pivotal role designers and retailers can play in creating a more sustainable industry. Research will highlight the specific role retailers can play in promoting sustainable fashion. Vivienne Westwood, Levi's, PUMA, MEC, Patagonia and Marks and Spencer are all leading global brands with strong sustainability standards.

\subsection{Conclusion}

Through a mixed method approach research is able to collect both quantitative and qualitative analysis. Methodology one, the literature review, looks to illustrate the negative environmental impacts of the fashion industry, the growing awareness of the impacts and the increase in VIs addressing these issues. Methodology two uses Nvivo software to determine key trends in sustainability reporting throughout the fashion industry by analyzing the CSR reports of leading retailers. Methodology two looks to highlight key words used throughout the reports and to track similarities (or lack thereof) in reporting methods used throughout the industry, identify substantive developments in sustainable fashion and the emerging challenges and issues impacting sustainability. Methodology three, lesson drawing, research aims to draw on parallels between and fair trade type certified coffee and sustainable cotton for the fashion industry. Research is looking to highlight lessons the fashion industry can learn from fair trade coffee by appealing to conscientious consumers with the guarantee that by purchasing sustainable fashion the value is shared throughout the supply chain, mitigating environmental damage caused by manufacturing. Methodology four highlights the key role retailers can play in addressing sustainability issues by featuring key retailers that have made their sustainability part of their core business practices.

\section{Chapter 4 Data Summary - Characteristics and Qualitative Analysis}

\subsection{Introduction}

CSR reporting on sustainability targets and goals is becoming more pervasive in the fashion industry. This chapter will analyze and compare the CSR reports from the last five years (2009-2013) from five leading fashion retailers in the fast fashion and sports apparel sector. As there does not yet seem to exist a set standard for reporting on targets and initiatives, direct comparison is often difficult. Retailers 
report this as a difficulty, along with a lack of common definitions and vocabulary for the fashion industry. Retailers cited numerous challenges to improving overall sustainability throughout the supply chain. Challenges and barriers include; lack of common standards, continually changing information regarding materials, lack of access to information (for designers), and insufficient focus on materials innovation (NIKE CSR, 2013). NIKE has attempted to address this by creating their Material Sustainability Index and has been working with the Sustainable Apparel Coalition to help improve the HIGG index. As the literature review demonstrated, the fashion industry generates considerable environmental impacts through textile production and process, garment manufacturing and consumer consumption and disposal. The entire lifecycle of the retailers supply chains are addressed and their CSR reports are compared below based on the following four categories; Waste, Water, Energy and CO2.

Each of the five retailers, Adidas, Gildan, H\&M, Inditex and NIKE have all joined various voluntary initiatives, adhering to their standards and goals. These initiatives tackle both social and environmental standards, but not cohesively. The sample set of retailers have identified textile production as creating the largest environmental impact through the use of pesticides, water use and the chemicals used in the dyeing and processing phase. Both NIKE and Adidas have come up with new processes to dye textiles using no water and decreasing the chemical and energy required by $50 \%$. Retailers also cite the consumer phase, specifically the disposal, as an area of concern. H\&M has implemented take back programs for their consumers at all of their retail locations; acting as a proxy for consumers by educating consumers on the recycling of clothing and by providing a simple option.

\section{Retail Sample Set}

Representing the five (5) most sustainable fashion retailers operating in Canada (Maclean's top 50 Socially Responsible Companies in Canada: 2014), the study's chosen sample retail set covers fast fashion specialty retailers and sports apparel and footwear retailers. Each of the five companies releases yearly annual reports and sustainability reports publicly disclosing corporate targets and their compliance with voluntary environmental and social standards and initiatives. The study's data is based on this publicly available data. Table 2 below lists the sample retailers, their 2013 sales and the CSR reports analyzed for their content analysis. 


\begin{tabular}{|c|c|c|c|}
\hline Retailer & Description & Sales & CSR Reports \\
\hline Adidas & $\begin{array}{c}\text { Sports and athletic } \\
\text { wear }\end{array}$ & $19.24 \mathrm{~B}$ & $\begin{array}{c}2009,2010,2011, \\
2012,2013\end{array}$ \\
\hline Gildan & $\begin{array}{c}\text { Sports and athletic } \\
\text { wear }\end{array}$ & & $\begin{array}{c}2009,2010,2011, \\
2012,2013 *\end{array}$ \\
\hline H\&M & Specialty Retailer & $20.28 \mathrm{~B}$ & $\begin{array}{c}2009,2010,2011, \\
2012,2013\end{array}$ \\
\hline Inditex & Specialty Retailer & & $\begin{array}{c}2009,2010,2011, \\
2012,2013\end{array}$ \\
\hline Nike & Sports and athletic & $22.25 \mathrm{~B}$ & $2007-2009,2010-$ \\
& wear & & $2011,2012-2013$ \\
\hline
\end{tabular}

Table 2 List of sample set of retailers and their CSR reports analyzed.

*No 2013 comprehensive report for Gildan was available. The 2013 Report was broken down into individual sections available online. Each report was downloaded and converted to a single report by the researcher in order to be used for NVivo content analysis.

\subsection{Sustainability in the Fashion Retail Sector}

\section{Defining Social Responsibility and CSR}

There is no set definition for social responsibility or CSR for retailers. CSR in the retail sector commonly addresses both social and environmental targets; however, reporting mechanisms differ from one retailer to the next. While there is no agreed upon universal definition for CSR, a commonly understood definition for social responsibility is outlined by the ISO 26000 Working Group on Social Responsibility (February 2007) as 'Social responsibility (is the) responsibility of an organization for the impacts of its decisions and activities on society and the environment through transparent and ethical behavior that is consistent with sustainable development and the welfare of society; it takes into account the expectations of stakeholders; is in compliance with applicable law and consistent with international norms of behavior; and is integrated throughout the organization'.

Increasingly, CSR activities are being understood by private businesses across all sectors, not just fashion. Recognition of the effect business activities have on employees, communities, consumers, shareholders and the environment is growing. Private firms are beginning to see the link between good business practices and good business (IISD, 2007). In addition, investors and financial markets are recognizing that CSR activities can interact directly with business strategy demonstrating good management thus providing companies with a competitive edge. In NIKE's 2013 sustainability report, 
NIKE reported that improving environmental standards, including reducing waste and improving efficiency, could improve the company's competitiveness.

Despite these advances in understanding the link between responsible business practices and good business, there still remains a degree of confusion and controversy surrounding CSR. Most prominently from a business perspective, is the implementation of CSR practices a cost or a value-enhancer for companies (IISD, 2007)? From the consumer perspective, is a CSR strategy just public relations or green washing? To be truly transformational, CSR practices must be integrated directly into business practices, not implemented as an afterthought.

Businesses are integral to the communities they serve, and good executives understand that long-term success is based on strong relationships with those communities. Increasingly consumers are coming to expect goods that are both socially and environmentally conscious (IISD, 2007). In addition, through the advancement of technology, access to information and social media, consumers now have more and more tools to hold companies responsible.

\section{Sample Set Sustainability Standards and Targets}

Sustainability and corporate social responsibility (CSR), though not new terms, remain contested in a business sense and especially so in the fashion industry. There have been many apparel and textile studies that have used the term social responsibility or CSR, but few have offered a definition, and there has yet to be a universally accepted specific definition for either term (Dickson \& Eckman, 2006). In a broad sense, sustainability and CSR in the fashion sector seems to encompass the triple bottom line; people, planet and profit. It remains a challenge for retailers to act in the best interest of society and the environment while acting in the best interest of its shareholders. This study will analyze the environmental concerns of the sample set of five retailers addressed through their respective CSR reports.

CSR Reporting across the retail sample set dates back as early as 1998 (Adidas). Releasing CSR reports with commitments towards both social and environmental standards is now the norm throughout the fashion retail sector. Of the five retailers researched all have released CSR reports detailing environmental targets and commitments since 2004. Gildan Activewear was the last of investigated firms to release a CSR report, releasing its first report in 2004. The CSR reports cover both 
environmental and social targets; however, for the purpose of this study only environmental targets will be analyzed. Currently, CSR reports outlining each retailer's social and environmental commitment are released separately from their annual reports indicating sustainability actions are not integrated directly into core business practices. It can be argued that change will more readily occur when retailers release sustainability targets and initiatives directly in their annual reports.

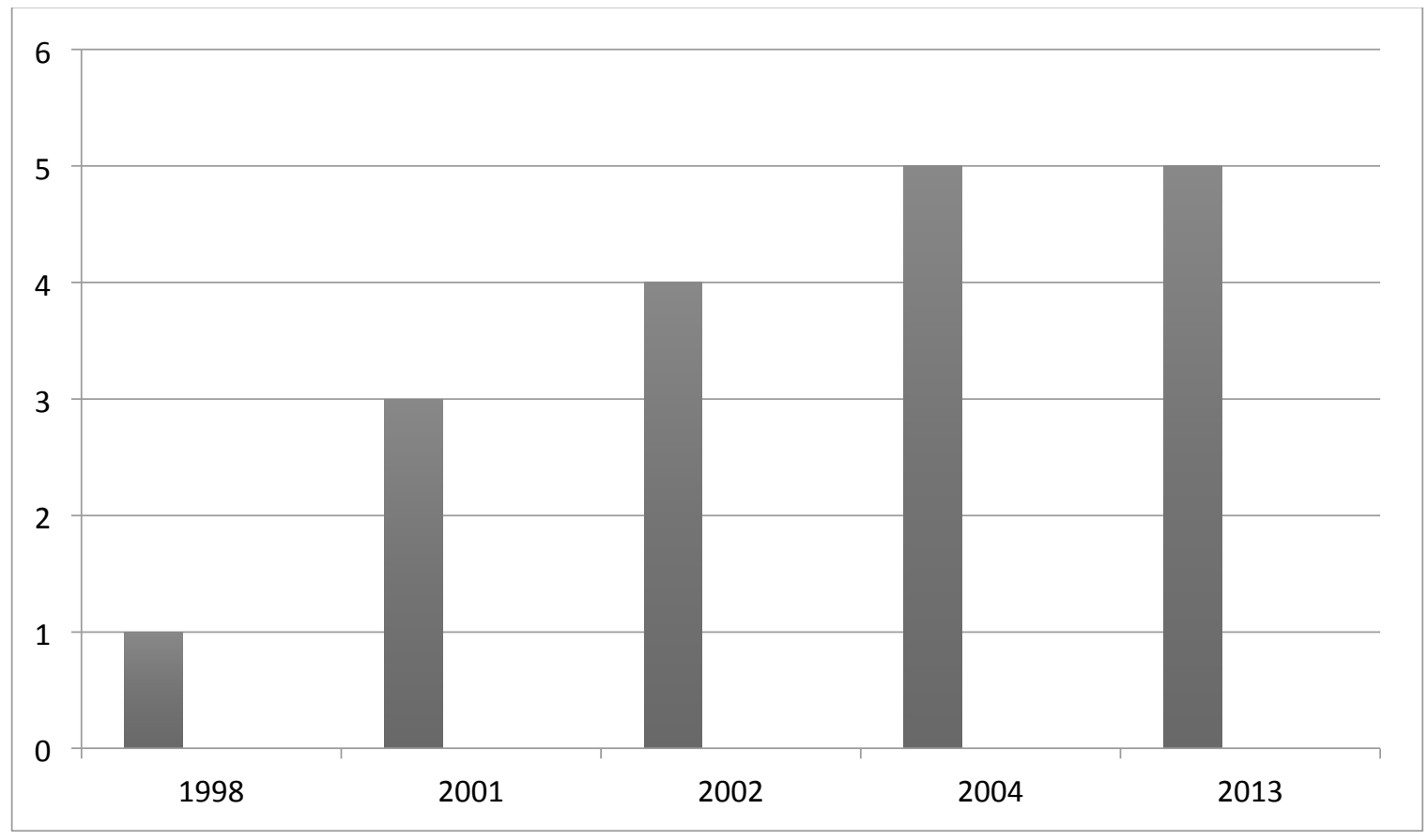

Figure 4 Source Author: Published CSR Reports by sample set of fashion retailers.

\subsection{Qualitative Content Analysis \\ Best Practices}

Assessing the sample population of the fashion retailers' published reports; sustainability was unanimously reported on and highlighted as playing a key role in business practices. The percentage of the word sustainable/sustainability has increased each year from 2009 to 2013 across all CSR reports from Adidas, Gildan, H\&M, Inditex and Nike (shown in table 4.2 below). The increase in the use of the word sustainability each year demonstrates that retailers understand the importance of reporting on sustainability issues throughout their supply chains. The following sections will unpack the sustainability commitments of each of the five chosen retailers by tracking their waste, water, $\mathrm{CO} 2$, and energy targets and commitments. Waste, water, $\mathrm{CO} 2$ and energy are the four key environmental concerns addressed by fashion retailers. 
Using NVivo qualitative analysis software, a word search indicated the 100 most frequently used words in publications from the sample retail set from 2009 to 2013. Table 3 displays the most frequently used words associated with sustainability used across all reports over the reporting periods of 2009-2013. Sustainable was the most frequent word, appearing 4280 times (0.573\%) across all reports. Environmentally was used second most frequently $(0.40 \%)$ followed by socially $(0.28 \%)$ and risks (0.23\%).

As stated in Chapter 1, there does not yet exist a singular definition of sustainability for the fashion industry, and this is demonstrated through the CSR reports of each of the sample population addressed in the section below. Unlike certification programs like LEED, which address building efficiency and sustainability in a standardized way, there is no standard for the fashion industry to report on sustainability targets. Due to this lack of consistency, comparison on retail sustainability standards is difficult (Gam, 2007). Each company defines sustainability targets and objectives in their own format. However, there are trends that emerge throughout each report. Table 4 showcases the trends on the reporting of sustainability-orientated words (using the sample identifying sustainability words from Weise et al (2010) and SSI (2014)) from 2012 to 2013. Sustainable/sustainability remains the most frequently used word both in 2012 and 2013. Water, fair trade, energy and organic follow in frequency between 2012-2013 with the word environmental falling in frequency between 2012-2013.

Table highlights the five-year trend (2009-2013) and frequency of sustainability, water, fair trade, energy and organic as reported across all five retailers' CSR reports. The search shows that energy and organic are declining in frequency. Figure 6 reveals the use of the word fair trade has seen a significant peak in frequency from 2012 to 2013. This may be attributed to the collapse of the garment factory in Rana Plaza in 2013 where 1,137 garment workers lost their lives. Following the collapse, retailers have placed a greater emphasis on worker safety and working conditions. 2013 saw major retailers come together to sign safety agreements for Bangladesh through the Bangladesh Safety Accord. In addition, large retail brands such as Patagonia and MEC are beginning to offer Fairtrade options. Fairtrade in the fashion industry will be addressed further in Chapter 5 . 


\begin{tabular}{|c|c|c|c|c|c|}
\hline Word & Total Count & $\begin{array}{c}\text { Frequency } \\
\text { (percentage) }\end{array}$ & Word & Total Count & $\begin{array}{c}\text { Frequency } \\
\text { (Percentage) }\end{array}$ \\
\hline Sustainable & 4289 & $0.57 \%$ & Impacts & 1727 & $0.19 \%$ \\
\hline Environmentally & 3562 & $0.40 \%$ & Codes & 1593 & $0.18 \%$ \\
\hline Socially & 2494 & $028 \%$ & Water & 1456 & $0.16 \%$ \\
\hline Risks & 2095 & $0.23 \%$ & Safety & 1183 & $0.13 \%$ \\
\hline Compliance & 2034 & $0.23 \%$ & Health & 1141 & $0.13 \%$ \\
\hline Conduct & 1852 & $0.21 \%$ & Waste & 1088 & $0.12 \%$ \\
\hline Processing & 1789 & $0.20 \%$ & Environment & 1068 & $0.12 \%$ \\
\hline
\end{tabular}

Table 3 Source Author: 100 NVivo Most Frequent 'sustainability type' words across all fashion reports from 2009-2013. Frequency tracked using NVivo software.

\begin{tabular}{|c|c|c|c|c|c|}
\hline Word & $\mathbf{2 0 1 2}$ & $\mathbf{2 0 1 3}$ & $\mathbf{2 0 1 2 / 2 0 1 3}$ \\
\hline $\begin{array}{c}\text { Average } \\
\text { Count }\end{array}$ & $\begin{array}{c}\text { Average } \\
\text { Percentage } \\
\mathbf{( \% )}\end{array}$ & $\begin{array}{c}\text { Average } \\
\text { Count* }\end{array}$ & $\begin{array}{c}\text { Average } \\
\text { Percentage } \\
\text { (\%) }\end{array}$ & $\begin{array}{c}\text { Cumulative } \\
\text { Percentage } \\
\text { (\%) }\end{array}$ \\
\hline $\begin{array}{c}\text { Sustainability/ } \\
\text { Sustainable }\end{array}$ & 264 & $0.77 \%$ & 278 & $0.87 \%$ & $0.82 \%$ \\
\hline Water & 95 & $0.10 \%$ & 113 & $0.13 \%$ & $0.125 \%$ \\
\hline Fair Trade & 52 & $0.04 \%$ & 82 & $0.10 \%$ & $0.07 \%$ \\
\hline Energy & 82 & $0.10 \%$ & 62 & $0.08 \%$ & $0.09 \%$ \\
\hline Organic & 57 & $0.11 \%$ & 35 & $0.07 \%$ & $0.09 \%$ \\
\hline $\begin{array}{c}\text { Carbon } \\
\text { Footprint }\end{array}$ & 31 & $0.06 \%$ & 31 & $0.07 \%$ & $0.65 \%$ \\
\hline $\begin{array}{c}\text { Environment/ } \\
\text { Environmental }\end{array}$ & 59 & $0.14 \%$ & 28 & $0.06 \%$ & $0.10 \%$ \\
\hline Waste & 64 & $0.06 \%$ & 60 & $0.06 \%$ & $0.06 \%$ \\
\hline GHG) & 42 & $0.04 \%$ & 36 & $0.04 \%$ & $0.04 \%$ \\
\hline Green & 23 & $0.03 \%$ & 12 & $0.02 \%$ & $0.025 \%$ \\
\hline Biodiversity & 8 & $0.01 \%$ & 7 & $0.01 \%$ & $0.01 \%$ \\
\hline Synthetic Inputs & 6 & $0.01 \%$ & 7 & $0.01 \%$ & $0.01 \%$ \\
\hline $\begin{array}{c}\text { GMO } \\
\text { Prohibition }\end{array}$ & 4 & $0.01 \%$ & 4 & $0.01 \%$ & $0.01 \%$ \\
\hline Soil & 2 & $0.01 \%$ & 0 & $0.0 \%$ & $0.005 \%$ \\
\hline Eco-Friendly & 0 & 0 & 0 & 0 & $0 \%$ \\
\hline Eco-Marketing & 0 & 0 & 0 & 0 & $0 \%$ \\
\hline
\end{tabular}


Table 4 Source: Author: Frequency of 16 words chosen for word content analysis through Sustainability in Retailing-a Summative Content Analysis (Wiese et al 2010) and SSI 2014 report. Frequency tracked using NVivo software.

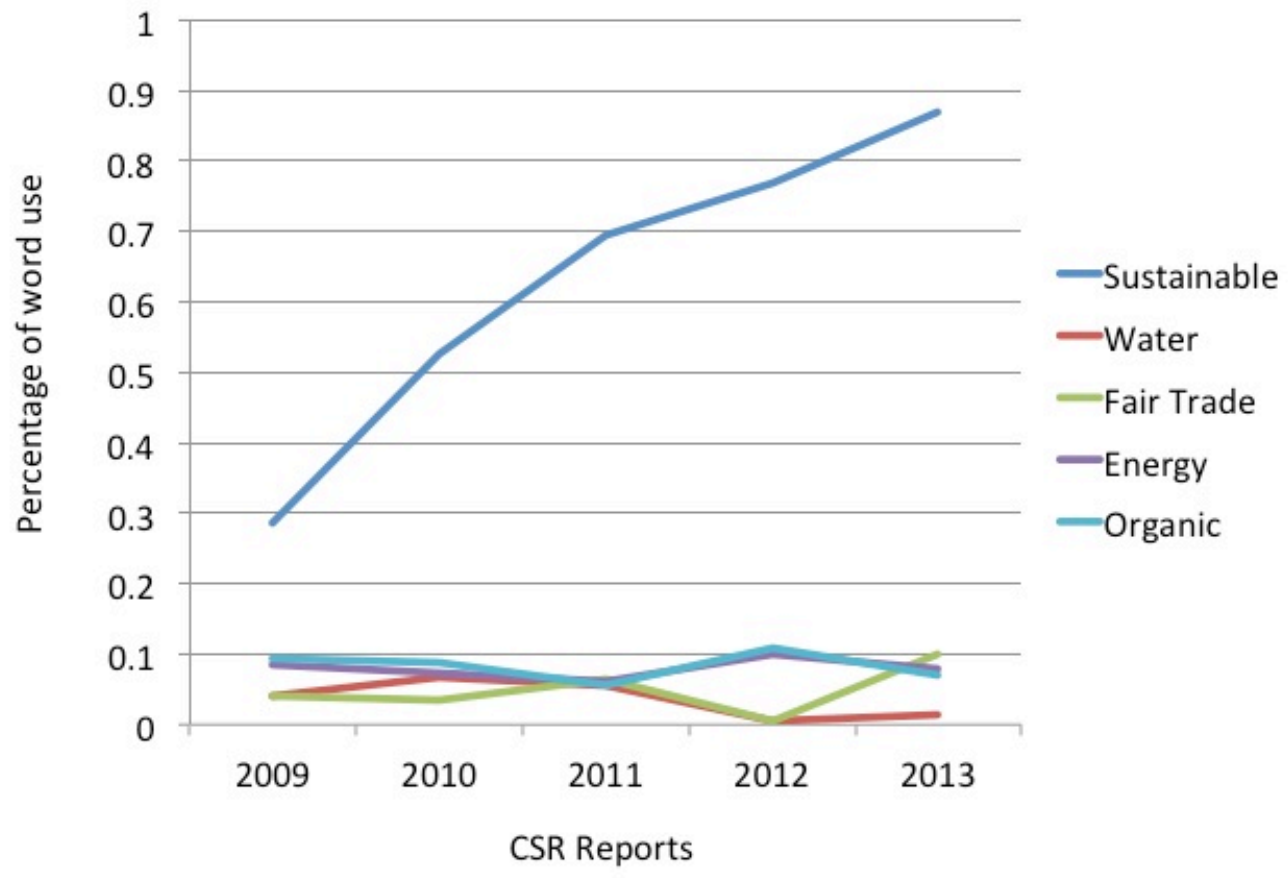

Figure 5 Source, Author: Word content use across all reports from 2009-2013. Frequency tracked using NVivo software.

\subsection{Top CSR Goals in Fashion Retail Industry}

Document content analysis and review of CSR reports indicates that the sample set of retailers report on both environmental and social issues. Social commitments can include, but are not limited to the following; workplace safety, factory audits, right to unionize, anti-harassment standards, fair pay, child labour, employee diversity, health care services and training. Each of the sample set of retailers addresses social concerns throughout their reports. While this research does acknowledge that social concerns for the fashion sector must be included in comprehensive voluntary initiatives, for the purpose of this paper research focuses on environmental concerns and issues.

The study's sample retail set all reported on their environmental commitments as part of their overall CSR reporting framework. Waste management and reduction, water reduction (specifically focusing on closed loop systems), energy efficiency and $\mathrm{CO} 2$ reduction were highlighted across all reports as leading 
common CSR objectives (detailed in the section and tables below). Each of the reports differed in length and detail. Gildan's 2013 CSR report was the least comprehensive and the only of the five retailers to not be part of the Greenpeace Detox challenge and the only retailer to not source cotton from the Better Cotton Initiative $(\mathrm{BCl})$. The Greenpeace Detox Challenge, $\mathrm{BCl}$, Organic Cotton and the Sustainable Apparel Coalition (all VI for the fashion industry) will be further discussed in Chapter 5. Table 5 shows which voluntary code each of the five retailers from the sample set complies with.

\begin{tabular}{|l|c|c|c|c|}
\hline Initiative & $\begin{array}{l}\text { Better } \\
\text { Cotton } \\
\text { Initiative }\end{array}$ & $\begin{array}{l}\text { Greenpeace } \\
\text { Detox } \\
\text { Challenge }\end{array}$ & $\begin{array}{l}\text { Organic } \\
\text { Cotton }\end{array}$ & $\begin{array}{l}\text { Sustainable } \\
\text { Apparel } \\
\text { Coalition }\end{array}$ \\
\hline Adidas & $\mathrm{X}$ & $\mathrm{X}$ & $\mathrm{X}$ & $\mathrm{X}$ \\
\hline Gildan & & & $\mathrm{X}$ & $\mathrm{X}$ \\
\hline H\&M & $\mathrm{X}$ & $\mathrm{X}$ & $\mathrm{X}$ & $\mathrm{X}$ \\
\hline Indidtex & $\mathrm{X}$ & $\mathrm{X}$ & $\mathrm{X}$ & $\mathrm{X}$ \\
\hline Nike & $\mathrm{X}$ & $\mathrm{X}$ & $\mathrm{X}$ & $\mathrm{X}$ \\
\hline
\end{tabular}

Table 5 Source, Author: List of environmental VI used by the sample Retail set.

\subsection{Environmental Targets}

The five sample retailers reported on environmental targets extensively throughout their CSR reports. As the NVivo word content analysis demonstrated, sustainability was the dominating trend throughout the reports. Specific targets and commitments saw an increase in reporting from 2009 to 2013. The words Water, Fair Trade, Energy and Organic saw an increase in prevalence throughout the reports from 2009-2013. The increase in the use of 'fair trade' throughout the sample set of retailers demonstrates an emerging recognition of the need to address both sustainability and ethical issues throughout the supply chain. Further examination of the CSR reports revealed that the term fair trade is most often used when referring to cotton. The use of fair trade to address the entire supply chain has not yet emerged among major retailers. Further detail on fair trade in the fashion industry will be addressed in Chapter 5 .

The following section will detail the targets set out by each of the five retail set across the four major sectors; waste, water, energy and CO2. Using the CSR reports, the research will track progress and trends across the sample set. 


\begin{tabular}{|l|c|c|c|c|}
\hline \multicolumn{5}{|c|}{ Target Sector } \\
\hline Retailer & Waste & Water & Energy & C02 \\
\hline Adidas & $\mathrm{X}$ & $\mathrm{X}$ & $\mathrm{X}$ & $\mathrm{X}$ \\
\hline Gildan & $\mathrm{X}$ & $\mathrm{X}$ & $\mathrm{X}$ & $\mathrm{X}$ \\
\hline H\&M & $\mathrm{X}$ & $\mathrm{X}$ & $\mathrm{X}$ & $\mathrm{X}$ \\
\hline Inditex & $\mathrm{X}$ & $\mathrm{X}$ & $\mathrm{X}$ & $\mathrm{X}$ \\
\hline Nike & $\mathrm{X}$ & $\mathrm{X}$ & $\mathrm{X}$ & $\mathrm{X}$ \\
\hline
\end{tabular}

Table 6 Source, Author: Each of the sample set of retailers reported on waste, water, CO2, and energy in their CSR reports.

\subsubsection{Waste Management}

Hazardous and non-hazardous waste diversion and reductions rates were reported throughout each of the 2013 CSR reports across the sample set. Overall, retailers had simple waste targets; use less and buy less to reduce impact throughout the value chain (Nike, Adidas, H\&M, Gildan \& Inditex, 2013).

H\&M's CEO, Karl-Johan Person, wrote in the introduction of H\&M's 2013 CSR Report that when he looked ahead to the future of H\&M and fashion he envisioned a future where the way fashion is consumed and made will change. Person stated $(2013$, p.3)

I hope that we will produce fashion in a closed loop, using less of our planet's resources and reducing waste instead. For the resources that we still need, we must share them fairly between today's and future generations. That means for example that today we are setting the direction so that we play our part in ensuring there will be enough clean water for everyone.

Generally, all retailers in the sample set have set waste reduction goals through pattern efficiency, landfill diversion and reuse. In 2012, Nike released Nike Materials Sustainability Index (MSI) that became part of the Higg Index used by the Sustainable Apparel Coalition. The MSI is intended to create a common language and set of definitions related to a garments material footprint. NIKE also released the NIKE Making It App for smartphones, which allows designers and consumers to track the environmental footprint and impact of over 30 different textiles. The Making It App allows designers and consumers to compare the impacts of textiles against one another in terms of CO2, energy, waste, water use and chemistry (NIKE, 2013). Despite these advances and innovations put forth by the fashion industry, there does not yet exist common standard for tracking sustainability practices. Each of the five retailers used different reporting methods, making a direct comparison difficult. Retailers compared environmental improvements against different base years, and data was not tracked consistently between the retailers. However, throughout the CSR reports of the sample retail set, trends emerged on waste reduction targets. Detailed below is an overview of the waste reduction strategies set forth by the five retailers. 
Table 7 depicts the targets each retailer has set in their waste management strategy. Targets include overall waste reduction. Both Adidas and Gildan set a target in 2010 to reduce waste sent to landfills by $25 \%$ by 2015 . In 2013 Gildan met their 2010 target reducing their waste by $25 \%$, in addition, of the waste generated 91\% was recycled (Gildan, 2013). Gildan is re-evaluating their processes and will set new goals for 2015. Adidas launched a 'low waste initiative' to maximize performance while minimizing waste and set a target of $25 \%$ waste reduction per employee by 2015 . Both NIKE and Adidas set aggressive targets for their footwear manufacturing to improve efficiency in the manufacturing process of their shoes and in improving their shoeboxes. Nike's waste target is to achieve a $10 \%$ reduction from finished goods throughout the entire supply chain, including packaging from their 2011 baseline through to 2015. To address these targets, NIKE began working on packaging efficiency in 1995, making their shoeboxes from $100 \%$ recycled content. Since 1995, they have reduced the weight of the box. The new box is a 3\% weight reduction from their 2011 baseline.

End-of life and consumer engagement in textile recycling were priorities for both H\&M and Inditex. Inditex has begun to look at the end-of life of their garments believing disposal of garments to be the last option, stating that they believe 'the best way to reuse a garment or textile waste is that which modifies the product as little as possible' (Inditex, 2013, p.87).

H\&M's 2013 waste reduction targets focused heavily on reuse and recycling of garments. In 2012, H\&M partnered with I:CO, a leader in textile recycling, to launch an initiative collecting clothing from consumers at H\&M retail locations. By the end of 2013, all H\&M retail locations were equipped with consumer recycling boxes to encourage consumers to recycle their textile waste. In 2013, Inditex engaged in consumer recycling through its brand Tempe, in collaboration with A Puntadas to make mouse pads from reused leather waste from cutting room floors and samples. The leather mouse pads were then sold at Tempe stores. 


\begin{tabular}{|c|c|c|c|c|c|c|}
\hline $\begin{array}{l}\text { Waste } \\
\text { Target }\end{array}$ & $\begin{array}{l}\text { Pattern } \\
\text { efficiency }\end{array}$ & $\begin{array}{l}\text { Warehouse } \\
\text { Recycling }\end{array}$ & $\begin{array}{l}\text { Retail Store } \\
\text { Recycling }\end{array}$ & $\begin{array}{l}\text { Reuse of } \\
\text { materials }\end{array}$ & $\begin{array}{c}\text { Garment } \\
\text { Collection from } \\
\text { Consumers }\end{array}$ & Packaging \\
\hline Adidas & $\begin{array}{l}\text { One F/W } 2013 \\
\text { collection achieved } \\
95 \% \text { pattern } \\
\text { efficiency. }\end{array}$ & $\begin{array}{l}\text { On target to divert } \\
1,500 T \text { of } \\
\text { polystryne waste } \\
\text { form landfills each } \\
\text { year }\end{array}$ & $\begin{array}{l}\text { On target to } \\
\text { reduce employee } \\
\text { waste by } 25 \%\end{array}$ & $\begin{array}{l}\text { Waste generated } \\
\text { from F/W } \\
\text { pattern efficient } \\
\text { collection went } \\
\text { to a recycling } \\
\text { factory to make } \\
\text { teddy bear } \\
\text { stuffing }\end{array}$ & No reporting & $\begin{array}{l}\text { In 2013, trialed } \\
\text { the single } \\
\text { walled cartons } \\
\text { by Adidas } \\
\text { China. From } \\
\text { October to } \\
\text { December } \\
2013 \text {,saved a } \\
\text { total of } 6 \\
\text { tonnes of paper }\end{array}$ \\
\hline Gildan & $\begin{array}{l}\text { Since } 2010 \text {, } \\
\text { decreased waste } \\
\text { sent to landfills by } \\
25 \%\end{array}$ & $\begin{array}{l}\text { Increased \% of } \\
\text { recovered waste in } \\
\text { production. } \\
\text { Cardboard wood } \\
\text { pellets and reels of } \\
\text { yarn used as } \\
\text { biomass in broilers }\end{array}$ & N/A & $\begin{array}{l}\text { Gildan currently } \\
\text { does not use } \\
\text { recycled input } \\
\text { materials in their } \\
\text { products }\end{array}$ & $\begin{array}{l}\text { Gildan currently } \\
\text { does not have a } \\
\text { take-back program }\end{array}$ & No Reporting \\
\hline H\&M & No reporting & $\begin{array}{l}\text { 2013: recycled } 92 \% \\
\text { of 32,000 tonnes } \\
\text { of waste produced } \\
\text { at warehouses. Set } \\
\text { target to recycle } \\
95 \% \text { for } 2013\end{array}$ & $\begin{array}{l}\text { 2013: on track by } \\
\text { increasing shares } \\
\text { of stores that } \\
\text { recycle main } \\
\text { types of waste }\end{array}$ & $\begin{array}{l}\text { Early } 2014 \text { saw } \\
\text { first launch of } \\
\text { products made } \\
\text { with recycled } \\
\text { fibers from } \\
\text { collected cloths. }\end{array}$ & $\begin{array}{l}\text { 2012: partnered } \\
\text { with I:CO. } \\
\text { Collected 3,047 } \\
\text { tonnes of } \\
\text { discarded } \\
\text { garments from } \\
\text { consumers-enough } \\
\text { to make } 15 \text { million } \\
\text { t-shirts }\end{array}$ & $\begin{array}{l}\text { All consumer } \\
\text { plastic bags are } \\
\text { made from } \\
100 \% \text { recycled } \\
\text { input materials. }\end{array}$ \\
\hline Inditex & $\begin{array}{l}\text { Textile wasted } \\
\text { decreased from } \\
905,143 \mathrm{~kg} \text { in } 2009 \\
\text { to } 625,074 \mathrm{~kg} \text { of } \\
\text { waste in } 2013\end{array}$ & $\begin{array}{l}\text { Cardboard boxes } \\
\text { that clothing is } \\
\text { delivered to stores } \\
\text { in are recycled as } \\
\text { often as possible. }\end{array}$ & $\begin{array}{l}\text { Dedicated areas } \\
\text { containing } \\
\text { recycling and } \\
\text { waste compactors } \\
\text { at retails stores. }\end{array}$ & $\begin{array}{l}\text { Tempe, an } \\
\text { Inditex brand, } \\
\text { used leather } \\
\text { waste from } \\
\text { cutting room } \\
\text { floors and } \\
\text { samples to make } \\
\text { 1,330 leather } \\
\text { mouse pads. }\end{array}$ & No reporting & $\begin{array}{l}\text { Group's (Inditex } \\
\text { brand) plastic } \\
\text { bags are oco- } \\
\text { biodegradable. } \\
\text { Paper bags FSC } \\
\text { certified }\end{array}$ \\
\hline NIKE & $\begin{array}{l}\text { Implemented } \\
\text { (MSI). } 8.6 \% \\
\text { reduction of } \\
\text { footwear waste. } \\
85 \% \text { of waste in } \\
\text { footwear } \\
\text { manufacturing is } \\
\text { reclaimed through } \\
\text { recycling or energy } \\
\text { recovery. }\end{array}$ & $\begin{array}{l}69 \% \text { of waste } \\
\text { diverted from } \\
\text { landfills (2013) } \\
\text { from NIKE world } \\
\text { headquarters; 92\% } \\
\text { waste diverted } \\
\text { from landfills } \\
\text { (2013) at } \\
\text { distribution } \\
\text { centers. }\end{array}$ & $\begin{array}{l}44 \% \text { waste } \\
\text { diverted from } \\
\text { landfills (2013) at } \\
\text { retail locations. } 2 \\
\text { Billion plastic } \\
\text { bottles recycled } \\
\text { into materials } \\
\text { used in products } \\
\text { since } 2010 .\end{array}$ & $\begin{array}{l}\text { Since 1990, } \\
\text { 'Resuse-A-Shoe' } \\
\text { program has } \\
\text { recycled } 28 \\
\text { million pair of } \\
\text { shoes into NIKE } \\
\text { grind. Used } \\
\text { primarily in turf } \\
\text { in fill for sport } \\
\text { surfaces and } \\
\text { fitness flooring. }\end{array}$ & $\begin{array}{l}\text { Reuse-A-Shoe } \\
\text { Program }\end{array}$ & $\begin{array}{l}3 \% \text { reduction in } \\
\text { weight of } \\
\text { shoeboxes. }\end{array}$ \\
\hline
\end{tabular}

Table 7 Source, author. 2013 Waste Targets and performance across retail sample set. 


\subsubsection{Water}

Retailers tracked their water footprint throughout the entire supply chain, demonstrating that it is the processing of raw materials and dyeing that generates the most use of water. Each of the retailers acknowledged the impact of water in the processing phase citing the need for closed loop systems to address these concerns. H\&M's 2013 report acknowledges the impact of cotton, their most widely used fiber. While cotton is a natural fiber that offers many design advantages, it presents many concerns specifically regarding water use and pesticides (addressed in Chapter 1 and 2). The average cotton t-shirt from H\&M requires 11 bathtubs of water to grow (H\&M, 2013). To address this concern, H\&M began working with $\mathrm{BCl}$ in 2002 to begin to source more responsible cotton. $\mathrm{H} \& \mathrm{M}$ uses recycled cotton and $\mathrm{BCl}$ cotton in order to address the environmental concerns of conventional cotton production. H\&M has increased their $\mathrm{BCl}$ and organic cotton consumption, by $2013,15.8 \%$ of cotton sourced by $\mathrm{H} \& \mathrm{M}$ was $\mathrm{BCl}$, organic or recycled.

All five of the sample set of retailers now source a portion of organic cotton in their supply chains. All retailers, with the exception of Gildan now source a portion of their cotton from $\mathrm{BCl}$ with each retailer setting targets to increase the amount of organic cotton sourced each year.

Industrial dyeing in the fashion industry contributes $17-20 \%$ of industrial freshwater pollution. It is estimated that 280,000 tonnes of dyestuffs (about $10-15 \%$ of total dyestuffs) used during the manufacturing phase is released, untreated, into the environment each year (Greenpeace Detox Campaign). $90.5 \%$ of Gildan's total water demands are a result of its dyeing process (Gildan, 20130). A wide range of organic compounds and complex structures are used for textile dyeing and finishing. The wastewater produced during the processing phase is not always biodegradable and can pose environmental concern. In 2011, Greenpeace launched their Detox Campaign '...to expose the direct links between global clothing brands, their supplier and toxic water pollution around the world' (Greenpeace Detox Campaign). Greenpeace asked major retailers around the world to commit to become toxic free by 2020. Each of the five retailers has signed on to the Detox Campaign. In 2013, Gildan completed construction on their first brine recovery system at one of their textile factories in Honduras. The system mechanically recovers salt from dye house effluents; the salt and water are then reused throughout different parts of the dyeing process. By the end of 2014, Gildan is set finish the interconnection piping to its facilities in Honduras to include the recovered brine into the process, 
expecting to save the company $400 \mathrm{~m} 3 /$ day of water at each facility where the system is implemented (Gildan, 2013).

Both Adidas and NIKE brought out dyeing technologies eliminating the need for water in the dyeing phase. Adidas' DryDye, launched in 2012, is a process using compressed carbon dioxide. The DryDye process converts the $\mathrm{CO} 2$ into both a liquid and a gas so the dyes can penetrate fibers without the need for additional chemicals. This process reduces both the energy need and chemical use by $50 \%$ (Adidas, 20132). NIKE launched their waterless dyeing process in 2012 by partnering with DyeCoo Textiles Systems B.V. out of the Netherlands. DyeCoo's process uses recycled CO2. These innovations in the dyeing process can allow the industry to begin to decrease their water usage in the dyeing phase, and decrease the amount of wastewater created by the dyeing phase. Table 8 below outlines the individual 2013 water targets of the sample retail set.

\begin{tabular}{|c|c|c|c|c|c|}
\hline Water Target & Adidas & Gildan & H\&M & Inditex & NIKE \\
\hline $\begin{array}{l}\text { Install water-efficient } \\
\text { equipment in all } \\
\text { stores, warehouses } \\
\text { and offices }\end{array}$ & $\begin{array}{l}\text { On target for } 2015 \\
20 \% \text { water } \\
\text { reduction/ } \\
\text { warehouse and } \\
\text { office employees. }\end{array}$ & $\mathrm{N} / \mathrm{A}$ & $\begin{array}{l}2020 \text { deadline } \\
\text { on track }\end{array}$ & $\begin{array}{l}\text { At eco-stores, } \\
\text { Inditex has } \\
\text { achieved } \\
\text { water saving } \\
\text { of } 50 \%\end{array}$ & $\begin{array}{l}793 \text { vendors } \\
\text { and contract } \\
\text { factories } \\
\text { participate in } \\
\text { the NIKE water } \\
\text { program }\end{array}$ \\
\hline $\begin{array}{l}\text { Reduce overall water } \\
\text { production/consumpti } \\
\text { on }\end{array}$ & $\begin{array}{l}\text { Implemented } \\
\text { DryDye } \\
\text { technology which } \\
\text { uses no water and } \\
\text { reduces chemical } \\
\text { and electricity use } \\
\text { by } 50 \%\end{array}$ & $\begin{array}{l}201510 \% \\
\text { consumption } \\
\text { reduction } \\
\text { target }\end{array}$ & $\begin{array}{l}\text { Year-to-year: } \\
\text { Done } \\
340 \text { fewer liters } \\
\text { used in denim } \\
\text { production }\end{array}$ & $\begin{array}{l}\text { Water } \\
\text { consumption } \\
\text { increased } \\
2013 \text { over } \\
2012, \text { mainly } \\
\text { due to } \\
\text { increase in } \\
\text { company } \\
\text { growth. } \\
\end{array}$ & $\begin{array}{l}816 \mathrm{M} \text { fewer } \\
\text { gallons used in } \\
\text { footwear } \\
\text { manufacturing } \\
\text { in } 2013 \\
\text { compared to } \\
2011.15 \% \\
\text { improvement in } \\
\text { water efficiency }\end{array}$ \\
\hline Use of Better Cotton & $\begin{array}{l}23 \% \text { Better Cotton } \\
\text { sourced in } 2013 \text {. } \\
2018 \text { target: } 100 \% \\
\text { better cotton }\end{array}$ & $\begin{array}{l}\text { No Better } \\
\text { Cotton. } \\
\text { Sources some } \\
\text { cotton from } \\
\text { Cotton USA } \\
\end{array}$ & $\begin{array}{l}15.8 \% \text { cotton } \\
\text { used is now } \mathrm{BCl} \\
\text { or organic }\end{array}$ & $\begin{array}{l}\text { Zara (Inditex } \\
\text { brand) has } \\
\text { launched a } \\
\text { line using } \mathrm{BCl}\end{array}$ & $\begin{array}{l}88 \% \text { of global } \\
\text { brand apparel } \\
\text { contains at least } \\
5 \% \text { organic } \\
\text { cotton }\end{array}$ \\
\hline $\begin{array}{l}\text { Develop method to } \\
\text { extend measuring and } \\
\text { reporting on water } \\
\text { impact reductions in } \\
\text { raw materials and } \\
\text { fabric production }\end{array}$ & $\begin{array}{l}2015 \text { Target: } \\
\text { Establish full } \\
\text { traceability of } \\
\text { more sustainable } \\
\text { materials. } \\
\text { Supports } \\
\text { Sustainable } \\
\text { Apparel Coalition } \\
\text { to further develop } \\
\text { Higg Index }\end{array}$ & $\begin{array}{l}2012 \text { started } \\
\text { brine recovery } \\
\text { at one textile } \\
\text { factory in } \\
\text { Honduras. } \\
\text { Brine used in } \\
\text { various stages } \\
\text { of dyeing } \\
\text { process used } \\
\text { to minimize } \\
\text { waste }\end{array}$ & $\begin{array}{l}\text { 2014: } \\
\text { on track }\end{array}$ & $\begin{array}{l}\text { Water } \\
\text { management } \\
\text { in use and } \\
\text { disposal. } \\
\text { Auditing and } \\
\text { technical } \\
\text { capacity- } \\
\text { building } \\
\text { program for } \\
\text { 'Zero } \\
\text { Discharge' and }\end{array}$ & $\begin{array}{l}\text { Implemented } \\
\mathrm{MSI}\end{array}$ \\
\hline
\end{tabular}




\begin{tabular}{|c|c|c|c|c|c|}
\hline Water Target & Adidas & Gildan & H\&M & Inditex & NIKE \\
\hline & & & & $\begin{array}{l}\text { 'Bangladesh } \\
\text { Water } \mathrm{PaCT}^{\prime}\end{array}$ & \\
\hline $\begin{array}{l}\text { Raise awareness on } \\
\text { water impact }\end{array}$ & $\begin{array}{l}\text { Member of } \\
\text { Greenpeace Detox } \\
\text { campaign }\end{array}$ & $\begin{array}{l}\text { Currently do } \\
\text { not provide } \\
\text { sustainability } \\
\text { impacts } \\
\text { information } \\
\text { on product } \\
\text { labels. }\end{array}$ & $\begin{array}{l}\text { Launched } \\
\text { 'Clever care' } \\
\text { label to inform } \\
\text { consumers. } \\
\text { Member of } \\
\text { Greenpeace } \\
\text { Detox campaign }\end{array}$ & $\begin{array}{l}\text { Eco label for } \\
\text { footwear. } \\
\text { Member of } \\
\text { Greenpeace } \\
\text { Detox } \\
\text { campaign }\end{array}$ & $\begin{array}{l}\text { Makinglt App } \\
\text { both consumer } \\
\text { and designer } \\
\text { facing. } \\
\text { Member of } \\
\text { Greenpeace } \\
\text { Detox campaign }\end{array}$ \\
\hline
\end{tabular}

Table 8 Source, Author. 2013 Water targets and performance across sample retail set.

\subsubsection{Energy Use}

The sample retail set highlighted the consumer end-phase as one the most energy intensive phases in the garment lifecycle. Lynn (2010) claims that washing and drying garments can account for an estimated $82 \%$ of energy use in a garment's lifecycle. However, NIKE reports total energy consumption of a garment in the 'consumer use phase' accounts for $24 \%$ of overall energy. Similarly, H\&M states that $26 \%$ of a garment's climate impacts occur in the consumer phase. H\&M addresses the issue of consumer care through their conscious actions. In 2011, H\&M partnered with Ginetex, the current leader in global standard care labelling systems. H\&M's target is to develop a common and mainstreamed consumer facing care label that encourages consumers to care for their clothing in a more sustainable way by reducing the water temperature of washing machines from $60 \mathrm{C}$ to $30 \mathrm{C}$. The Conscious Care label states that reducing the temperature of the washing machine by half requires $50 \%$ less energy (H\&M, 2013). H\&M is on target to have all products carrying the conscious care label by the end of 2014 .

NIKE reported that the design and material phase accounted for $54 \%$ of its overall direct energy consumption. Material production, from growing cotton to extracting oil for polyester and to raising livestock for leather, represents $23 \%$ of total energy use throughout the value chain for NIKE. Adding material processing phases such as dyeing and finishing, energy consumption increases to $54 \%$ of total energy use.

Renewable energy and energy efficiency were stated as goals across the sample set. H\&M now sources $18 \%$ of its entire energy from renewable energy and 147 of its retail locations are engaged in energy efficiency programs. Inditex now sources $45 \%$ of its energy from renewable sources at its head offices and factories. Gildan did not report on energy efficiency, but instead reported an increase in overall energy consumption in 2013 over 2012 levels. This increase in energy consumption can be attributed to 
a growth in production. Table 9 outlines the energy targets and goals as set out by the sample retail set in their 2013 CSR reports.

\begin{tabular}{|c|c|c|c|c|c|}
\hline Energy Targets & Adidas & Gildan & $H \& M$ & Inditex & NIKE \\
\hline $\begin{array}{l}\text { Supplier Energy } \\
\text { Reduction }\end{array}$ & $\begin{array}{l}10-15 \% \text { energy } \\
\text { consumption by } \\
\text { product output } \\
\text { reduction target }\end{array}$ & $\begin{array}{l}\text { Currently do not } \\
\text { report on. No } \\
\text { policies in place } \\
\text { to reduce } \\
\text { indirect energy } \\
\text { consumption as } \\
\text { related to } \\
\text { products. }\end{array}$ & $\begin{array}{l}\text { Engaged } 147 \\
\text { strategic } \\
\text { suppliers in } \\
\text { 'Supplier Energy } \\
\text { Efficiency } \\
\text { Program' } \\
\text { accounting for } \\
39 \% \text { of } \\
\text { production } \\
\text { volume }\end{array}$ & N/A & No Reporting \\
\hline $\begin{array}{l}\text { Energy Reduction at } \\
\text { Distribution \& logistics } \\
\text { Centres }\end{array}$ & $\begin{array}{l}2015 \text { target: } 30 \% \\
\text { less energy } \\
\text { consumption by } \\
\text { PC at offices }\end{array}$ & $\begin{array}{l}\text { Currently do not } \\
\text { report. Working } \\
\text { on developing } \\
\text { policies to } \\
\text { reduce energy } \\
\text { consumption } \\
\text { related to use of } \\
\text { products }\end{array}$ & No Reporting & $\begin{array}{l}\text { All logistics } \\
\text { centres have } \\
\text { Environmental } \\
\text { Management } \\
\text { System } \\
\text { certified in } \\
\text { accordance } \\
\text { with ISO } \\
14001 . \text { All } \\
\text { staff at } \\
\text { logistics } \\
\text { centre have } \\
\text { environmental } \\
\text { training }\end{array}$ & $\begin{array}{l}26 \% \text { reduction } \\
\text { in energy use } \\
\text { per unit } \\
\text { processed in } \\
\text { global } \\
\text { distribution } \\
\text { centers in } 2013 \\
\text { over } 2011\end{array}$ \\
\hline $\begin{array}{l}\text { Energy Reduction at } \\
\text { Corporate Offices } \\
\text { And stores }\end{array}$ & $\begin{array}{l}2015 \text { target: } \\
\text { reduce } \\
\text { environmental } \\
\text { footprint IT } \\
\text { structure by } 20 \% \\
\text { New lighting } \\
\text { system at } 5 \\
\text { distribution } \\
\text { centres, retrofit } \\
118 \text { retail stores } \\
\text { with LED lighting }\end{array}$ & $\begin{array}{l}\text { Energy } \\
\text { consumption at } \\
\text { offices } \\
\text { increased } 2013 \\
\text { over } 2012\end{array}$ & $\begin{array}{l}14 \% \text { energy } \\
\text { reduction (over } \\
2007 \text { ) at stores. } \\
\text { On track to } \\
\text { reduce by } 20 \% \\
\text { by } 2020\end{array}$ & $\begin{array}{l}\text { Inditex has } \\
\text { built } 1300 \\
\text { eco-efficient } \\
\text { stores since } \\
2007.420 \\
\text { stores } \\
\text { refurbished } \\
\text { according to } \\
\text { eco-efficient } \\
\text { model. Target: } \\
\text { All stores eco- } \\
\text { efficient by } \\
2020\end{array}$ & $\begin{array}{l}16 \% \text { energy } \\
\text { reduction per } \\
\text { square foot in } \\
\text { corporate } \\
\text { offices in } 2013 \\
\text { over } 2011 . \\
33 \text { Leed- } \\
\text { Certified stores }\end{array}$ \\
\hline $\begin{array}{l}\text { Renewable Energy } \\
\text { and Energy Efficiency }\end{array}$ & $\begin{array}{l}\text { 2012: Launched } \\
\text { greenEnergy } \\
\text { Fund. Venture } \\
\text { capital fund } \\
\text { accelerates } \\
\text { investment in } \\
\text { cost-effective } \\
\text { carbon and } \\
\text { energy reduction }\end{array}$ & $\begin{array}{l}2014 \text { \& } 2015 \\
\text { targets to } \\
\text { supply } 100 \% \\
\text { demand of } \\
\text { steam from } \\
\text { biomass over } \\
\text { electricity. } \\
\text { Energy intensity } \\
\text { across facilities }\end{array}$ & $\begin{array}{l}18 \% \text { of } \\
\text { electricity came } \\
\text { from renewable } \\
\text { sources in } 2013 . \\
147 \text { factories } \\
\text { engaged in } \\
\text { energy } \\
\text { efficiency } \\
\text { programs }\end{array}$ & $\begin{array}{l}\text { Renewable } \\
\text { energy } \\
\text { accounts for } \\
45 \% \text { of energy } \\
\text { consumed in } \\
\text { head offices } \\
\text { and factories. } \\
\text { Launched } \\
\text { Global Energy }\end{array}$ & $\begin{array}{l}2013 \text { developed } \\
\text { Sustainable } \\
\text { Business \& } \\
\text { Innovation } \\
\text { (SB\&I) team. } \\
\text { Trained supplier } \\
\text { factories on } \\
\text { energy } \\
\text { efficiency }\end{array}$ \\
\hline
\end{tabular}




\begin{tabular}{llllll}
\hline Energy Targets & Adidas & Gildan & H\&M & Inditex & NIKE \\
\hline & projects. & increased 6\% in & & Strategy & programs \\
& & 2013. & &
\end{tabular}

Table 9 Source, Author. Energy Targets 2013

\subsubsection{CO2 Emissions}

The sample set of retailers cited the greatest sources of $\mathrm{CO} 2$ throughout their value chains occurs outside their direct control; in growing raw material and finishing goods and in the consumer phase through washing and drying (NIKE, 2013). Both Adidas and NIKE report footwear manufacturing as the highest contributor, with NIKE reporting more than 57\% of their assessed $\mathrm{CO} 2$ emissions coming from footwear manufacturing (NIKE, 2013). Each of the retailers set targets to reduce CO2 emissions and absolute GHG emissions. NIKE reported a reduction of 2.8\% of overall CO2 emissions in 2013 over 2011 levels. Adidas has set an aggressive target to reduce CO2 emissions by 30\% by 2015 .

The transport of garments from production facilities to retail stores contributes to the firms' $\mathrm{CO} 2$ output. Each of the five retailers has suppliers and factories offshore; as a result transport often presents a high economic cost and environmental cost for retailers. Gildan and Inditex both reported an increase in $\mathrm{CO} 2$ emissions related to transport due to company growth. Despite growth, NIKE saw a $29 \%$ reduction in CO2 emissions per unit in transport in 2013 over 2011 levels. However, NIKE did not report on overall transport $\mathrm{CO} 2$ levels. Table 10 outlines the $\mathrm{CO} 2$ reduction targets and goals as set out by the sample retail set in their 2013 CSR reports

\begin{tabular}{|c|c|c|c|c|c|}
\hline Action & Adidas & Gildan & $H \& M$ & Inditex & NIKE \\
\hline $\begin{array}{l}\text { Relative Reduction in } \\
\mathrm{CO} 2 \text { emissions }\end{array}$ & $\begin{array}{l}2015 \text { target: } \\
\text { reduce CO2 } \\
\text { emissions by } 30 \%\end{array}$ & $\begin{array}{l}\text { Decrease in } \\
\text { absolute GHG } \\
\text { emissions } \\
\text { from } 2010 \text { to } \\
2013\end{array}$ & $\begin{array}{l}2015 \text { goal to } \\
\text { reduce total } \\
\text { amount of } \mathrm{CO} 2\end{array}$ & $\begin{array}{l}\text { Overall } \\
\text { decrease in } \\
\text { emissions } \\
\text { calculated } \\
\text { according to } \\
\text { GHG Protocol }\end{array}$ & $\begin{array}{l}2.8 \% \text { reduction } \\
\text { in overall CO2 } \\
\text { emissions in } \\
2013 \text { over } 2011\end{array}$ \\
\hline Transport & No Reporting & $\begin{array}{l}\text { GHG } \\
\text { emissions } \\
\text { intensity } \\
\text { decreased } \\
22 \% \text { over } \\
2012 \text { (includes } \\
\text { transport of } \\
\text { raw materials } \\
\text { and purchased } \\
\text { electricity at } \\
\text { facilities) }\end{array}$ & $\begin{array}{l}\text { Transport } \\
\text { accounts for } 6 \% \\
\text { of GHG } \\
\text { emissions of a } \\
\text { garment } \\
\text { Set a target to } \\
\text { ensure } 100 \% \text { of } \\
\text { transport } \\
\text { service } \\
\text { providers are } \\
\text { participating or }\end{array}$ & $\begin{array}{l}\text { Increase in } \\
\text { CO2 emissions } \\
\text { related to } \\
\text { transport due } \\
\text { to company } \\
\text { growth }\end{array}$ & $\begin{array}{l}29 \% \text { reduction } \\
\text { in CO2 } \\
\text { emissions per } \\
\text { unit in transport } \\
\text { in } 2013 \text { over } \\
2011\end{array}$ \\
\hline
\end{tabular}




\begin{tabular}{|c|c|c|c|c|c|}
\hline Action & Adidas & Gildan & $H \& M$ & Inditex & NIKE \\
\hline & & & $\begin{array}{l}\text { registered in } \\
\text { energy efficient } \\
\text { transport-More } \\
\text { to do on this } \\
\text { target }\end{array}$ & & \\
\hline Product & $\begin{array}{l}\text { DryDye } \\
\text { technology uses } \\
50 \% \text { less energy } \\
\text { and } 50 \% \text { less } \\
\text { chemicals }\end{array}$ & $\begin{array}{l}\text { No reporting } \\
\text { per product }\end{array}$ & No reporting & $\begin{array}{l}\text { Decrease in } \\
\text { CO2 } \\
\text { emissions/ } \\
\text { garment } \\
\text { released. } \\
322.52 \mathrm{~g} \mathrm{CO2/} \\
\text { garment in } \\
2013 \text { over } \\
361.95 \mathrm{gCO} 2 / \\
\text { garment in } \\
2012 \\
\end{array}$ & $\begin{array}{l}17 \% \text { reduction } \\
\text { in CO2 } \\
\text { emissions in } \\
\text { footwear in } \\
2013 \text { over } 2011\end{array}$ \\
\hline Facilities and Offices & $\begin{array}{l}\text { Invested in solid } \\
\text { oxide fuel cell at } \\
\text { TaylorMade } \\
\text { Adidas Golf } \\
\text { facility-alternative } \\
\text { energy reduces } \\
\text { facility's carbon } \\
\text { emissions by } 28 \%\end{array}$ & $\begin{array}{l}15 \% \text { reduction } \\
\text { of both direct } \\
\text { and indirect } \\
\text { emissions } \\
\text { over } 2012 \text {. }\end{array}$ & $\begin{array}{l}\text { Target: grow by } \\
10-15 \% \text { new } \\
\text { stores each year } \\
\text { without } \\
\text { additional } \\
\text { climate impact }\end{array}$ & & $\begin{array}{l}2013 \text { developed } \\
\text { Sustainable } \\
\text { Business \& } \\
\text { Innovation } \\
\text { (SB\&I) team. } \\
\text { Trained supplier } \\
\text { factories on } \\
\text { energy } \\
\text { efficiency } \\
\text { programs }\end{array}$ \\
\hline
\end{tabular}

Table 10 Source, Author. CO2 targets 2013

\subsection{Conclusion: Summary of CSR Targets}

Retailers cited numerous challenges to improving overall sustainability throughout the supply chain.

Challenges and barriers include; lack of common standards; continually changing information regarding materials, lack of access to information (for designers), and insufficient focus on materials innovation (NIKE CSR 2013). NIKE reported that improving environmental standards, including reducing waste and improving efficiency could improve the company's competitiveness (NIKE CSR, 2013). Firms cited that reducing their contributions to climate change was the primary aim of their sustainability strategies (Adidas, Gildan, H\&M, Inditex \& NIKE, 2013). Each retailer set out a number of specific targets relating to energy, CO2 emissions, waste and water. NIKE remains at the forefront of innovation, creating the Material Sustainability Index, rating materials on their sustainability factors, energy, water and chemistry. More efficient materials are rated more favourably, standing a better chance of being chosen by NIKE designers (NIKE, 2013). 
This summary of the CSR reports of five of the leading fashion retailers demonstrates the next potential shift in the industry, towards addressing sustainability across the supply chain. The 1990s witnessed isolated incidents affecting individual companies like Nike for accusations of the use of child labour. The 2000s witnessed an overhaul of corporate governance practices through failures of the like of Enron. The collapse of Rana Plaza in Bangladesh in 2013 accelerated these trends of holding corporations responsible. Following the collapse, retailers have come together to address safety and social concerns at offshore factories through the creation of accords like the Bangladesh Safety Accord. Increasingly, boards, in all business sectors, are looking to improve their CSR strategies (SSI Review 2014).

These five retailers demonstrate the advances in sustainability practices. H\&M claims to be a leader in sustainability by making a big investment in sustainability, and advocating to consumers through their 'Conscious Collection' line. H\&M claims sustainability is more than a PR initiative, and has refused to work with suppliers that will not comply with their sustainable and social standards. Like NIKE, H\&M states sustainability that respects both planet and people is a business case, beyond a sustainability case, as factories with strong employee practices see no strikes (H\&M, 2013). As some of the largest retailers in the world, Adidas, Gildan, H\&M, Inditex and NIKE have significant impact over the future of sustainability in the fashion industry.

Complete lifecycle assessments (LCA) allow companies to highlight areas of concern throughout their supply chains. Glldan began conducting LCAs in 2010 where they discovered water consumption and disposal, in textile manufacturing, have significant environmental impacts (Gildan, 2013). Since 2010, Gildan has been looking at ways to address their water consumption and disposal processes. H\&M is is addressing post-consumer waste and disposal by acting on behalf of their consumers by providing an easy way to recycle their textile waste directly at H\&M locations. Kozlowski, Bardecki \& Searcy (2012) highlight the importance of lifecycle assessment throughout the fashion supply chain siting that an LCA can help, despite the long and complicated lifecycle of garment production, provide an overall environmental profile. LCAs can help retailers discover how environmental, social and financial aspects of the fashion supply chain are all connected and demonstrate how they interact (Kozlowski, Bardecki \& Searcy, 2012).

The material phase remains the most resource heavy phase, using the most water and toxins throughout the supply chain. Each of the retailers from the sample set are addressing the environmental 
concerns presented by conventional materials such as cotton and polyester by looking to less intensive materials including organic and better cotton and recycled polyester. The use of organic or better cotton is on the rise, with each of the five companies setting targets to increase the amount of better cotton throughout their supply chain. $\mathrm{H} \& \mathrm{M}$ first partnered with $\mathrm{BCl}$ in 2002 and remains an active member. Since 2010, in partnership with WWF and Solidaridad, 300,000 cotton farmers have been trained to produce $\mathrm{BCl}(\mathrm{H} \& \mathrm{M}$ 2013). Through $\mathrm{BCl}$ farmers receive the know-how and tools to produce cotton with less impact on the environment while increasing their profit. H\&M set a 2015 target to train 1 million farmers by 2015.

The lack of cohesive standards to address the environmental impacts generated by the fashion industry make a direct comparison difficult. Each of the retailers reported on Waste, Water, Energy and CO2, but to varying degrees. In addition, retailers used different base years to set standards and targets. As such, an overall comparison of total waste reduction, water reduction, energy reduction and $\mathrm{CO} 2$ reduction could not be made, making it difficult to see overall trends. The retailers all acknowledged the need to improve their sustainability standards and metrics. CSR reports have become more in depth each year; the next step could be to create an industry standard for reporting, allowing for direct comparison between companies.

Companies like NIKE state that improving environmental standards can improve a company's competitiveness. NIKE's comprehensive CSR report uses scenario planning to understand the potential impact of their sustainability actions on their business and plan accordingly. NIKE looks beyond their processes to understand how external issues such as climate change and resource scarcity might affect business (NIKE, 2013). This understanding of external influences such as climate change on business practices and the financial and social interconnections is what will allow the fashion industry to see wider change adopted. Addressing environmental concerns cannot be seen as add on, but rather something that must be integrated into the company's core structures. With the creation of a standard initiative, code or labeling program that addresses environmental concerns presented throughout the fashion supply chain will make future research into sustainability trends easier to track. Chapter 6 will highlight leading retailers that have taken sustainability on as part of their mission and used it to their competitive advantage. 


\section{Chapter 5 Lesson Drawing: Fair Trade Coffee and Sustainable Fashion}

\subsection{Introduction}

Research is looking to find parallels between fair trade type certification for coffee and sustainable certification for fashion, particularly focusing on cotton. This chapter looks to fair trade type certification schemes for lessons that can be applied to the sustainable fashion market. Literature demonstrates that sustainable coffee production is one of the more mature markets in operation, and has acted as a testing ground for voluntary initiatives across commodities. Certification for coffee dates back to 1967; however, the first certification explicitly targeting coffee was introduced in Holland in 1988. The coffee sector has seen incredible growth over the past 10 years along with an increase in new schemes and mainstream adaptation. This chapter will outline the growth of fair trade type certification and its impact on farmers and the environment. Fair trade certification has extended to cotton production, thus making for a good comparison for the fashion industry. Of the many textiles used in the fashion industry, cotton is the most widely used and as such will be the focus of research. Voluntary initiatives for both the coffee and cotton industry will be highlighted and compared based on their mission, retail involvement, auditing process, commercial conditions, history and supply chain traceability. Research will draw parallels between both coffee and cotton.

\subsubsection{How Fair Trade-Type Certifications Work}

Fair trade-type certification functions as a multi stakeholder process addressing both social and environmental standards in the coffee sector. Fair trade-type certifications aim to ensure more equitable trading arrangements for disadvantaged farmers and producers and to promote social and environmental sustainability in the agricultural sector by developing standards and providing technical support. Standards are implemented through the multi stakeholder process by a third party entity. Third party certification allows for separate auditors to ensure that coffee brands and farmers meet their requirements. Individual coffee brands must go through the certification process using the third party auditor before they can use the label. Consumers identify and recognize labels as addressing both environmental and social issues. Fair trade-type certification addresses issues of maintaining biodiversity, climate change, worker health and safety and poverty. Pricing premiums for certified coffee ranges from 1 to $30 \%$, (in 2012). 
Following the 2001 coffee crisis, fair trade-type certified coffee has grown to represent $10 \%$ of total coffee sales. Fair trade type certification for coffee has seen considerable growth, resulting in social and environmental improvements for farmers growing fair trade coffee. In 2012, 3.3 million metric tonnes of fair trade-type certified coffee were produced, of which 840,000 metric tonnes were sold as certified, representing $25 \%$ of certified coffee produced and $10 \%$ of global production (SSI Review 2014). Certified coffee offers poverty reduction for producers in developing countries and ensures equitable trading arrangements for small producers. It is estimated that 20-25 million farmers grow coffee globally on 10.5 million hectares harvested.

\subsubsection{Fair trade coffee and sustainable fashion}

Fair trade-type certification for coffee was chosen as a comparison for sustainable fashion, specifically cotton manufacturing, as coffee and cotton share many similarities. Cotton and coffee provide the units of analysis to compare the specialty coffee industry and the fast fashion industry. While the comparison is not perfect, the two industries provide significant similarities. Both crops present social and environmental concerns requiring significant amounts of water and pesticides to grow and rely on cheap labour to harvest. Both cotton and coffee are widely grown in developing countries (with the exception of cotton grown in the US) where developing countries rely on the export of these crops. Coffee was chosen as a comparison over a label like 'organic' for food, as the organic movement is seen as a health movement. Consumers do not look to fair trade-type coffee or sustainable fashion as a health concern. The comparison as noted in Chapter 1 is not perfect; for example, there are specific retail facing coffee shops, but no retail facing cotton shops. Fashion offers a more complex supply chain, where cotton production only accounts for a portion of the supply chain. However, as demonstrated in Chapter 4, the manufacturing of textiles for fashion plays a major role in the environmental impacts of garment production. Table 11 below illustrates the commonalities and differences between coffee and cotton.

\begin{tabular}{|c|c|}
\hline Cotton & Coffee \\
\hline $\begin{array}{c}\text { Later, energy, pesticide } \\
\text { intensive }\end{array}$ & Wabour intensive \\
\hline $\begin{array}{c}\text { Grown in developing } \\
\text { countries and US }\end{array}$ & $\begin{array}{c}\text { Grown in developing } \\
\text { countries }\end{array}$ \\
\hline Insecure supply chain* & Insecure supply chain* \\
\hline Ethics based & Ethics based \\
\hline $\begin{array}{c}\text { Cotton is made into a textile } \\
\text { and then consumed by }\end{array}$ & Coffee is the end product \\
\hline
\end{tabular}




\begin{tabular}{|l|l|}
\hline fashion industry & \\
\hline No cotton shops & Coffee shops \\
\hline
\end{tabular}

Table 11Source, Author. Cotton and Coffee Commonalities Global coffee and cotton markets have been defined by high volatility and long term declining prices.

Fair trade consumer facing labels, (FLO, Rainforest Alliance and Fair trade Certified) have become recognizable and trusted labels among consumers, specifically for coffee, tea, chocolate and sugar. As such, the fair trade labeling and certification will be used to compare and contrast current initiatives within the fashion sector. Fair trade coffee and the fashion industry share similarities as both deal with consumable goods often produced in a developing nation where environmental and labour standards are lower than where they are sold in the market. As one of the most mature markets currently in operation, the coffee market has operating almost as a testing ground for many of the voluntary initiatives across commodities. The growth of both production and sales of sustainable coffee continues to grow at a rapid pace, with new initiatives entering the market UTZ (2002) and 4C (2006) (SSI Review, 2014). According to the SSI 2014 Review, trends demonstrate that sustainable and compliant coffee is here to stay, and soon one standard or another may become a requirement for the market.

Fair trade-type coffee certification was chosen over other labels, as fair trade has already begun to integrate with the fashion industry, specifically cotton. Fair trade cotton is on the rise, and production of fair trade cotton saw a 50\% growth in 2012 (SSI Review, 2014). Fair trade certified clothing is slowly entering the market, predominantly through fair trade certified cotton. In 2015, Patagonia is looking to further integrate fair trade clothing into their product line. In addition, smaller retailers are selling fair trade. The Azadi Project located in Toronto, Oliberte Shoes, the first Fair Trade Certified shoe factory in Africa, and MEC all offer fair trade garments. Chapter 6 will further highlight key retailers integrating fair trade cotton into their production.

Fair trade certification is label and consumer driven using retailers as proxies for consumers, working in a business to consumer model. Fair trade has a remarkable part of the market place for sustainable purchasing. In order to properly compare the fashion initiatives to that of fair trade certification, a set of guidelines has been set. Voluntary initiatives will be assessed based on the following: mission, history, commercial conditions, supply chain traceability, certification method, consumer communication and retail involvement. 
Coffee, similar to fast fashion at the current time, faced media, NGO and consumer scrutiny in 2000 as the industry was stung by charges of labour rights violations in Central American Plantations with the threat of large-scale protests and boycotts. In response, the coffee industry listened to consumer demands, fueled by the fear of boycotts, by increasing the prevalence of fair trade-type coffee options (Jaffee, 2012). Four of these options-FLO (fair trade labeling organization), Rainforest Alliance, 4C and UTZ will be highlighted throughout this research. The coffee crisis resulted in stakeholder collaboration with ICO to form the Sustainable Coffee Partnership, which called for greater reporting on sustainability standards and performance data in the coffee industry (SSI Review, 2014). Standard compliant production in the coffee industry now represents $40 \%$ of the market production share up from $15 \%$ over 2008 (SSI Review, 2014).

Following the coffee crisis in 2001, the fair trade coffee industry faced critiques regarding quality, cost to consumer and availability. The onset of sustainable fashion has seen similar challenges with sustainable fashion being critiqued for its high price, lack of availability and low quality or low design aesthetic. Fair trade coffee certifiers quickly realized that relying solely on ethics would not sell coffee. In order to convince consumers to pay a premium, the coffee had to be high quality (Jaffee, 2012). Fair trade coffee certifiers are still attempting to increase their market presence through consumer support and large corporate collaboration. Fair trade-type certification accounts for a growing share of market production (40\%). Sales of certified coffee represents $10 \%$ of the market share (SSI Review, 2014), growing from $0 \%$ in 1990 following the coffee crisis. Fair trade certifiers realized the link between marketing and labeling activities. Therefore, consumer facing models and labels, such as the fair trade (FLO), Fair Trade Certified and Rainforest Alliance labels that inform consumers about production practices are often linked with educational information. Labeling can provide a way for brands to differentiate themselves from their competition. Consumer facing models seek to increase consumer demand for sustainable products (SSI Review, 2014). This lesson of the power of consumer facing labels linked with educational information contributing to the increase in demand for sustainable goods can be applied to the fashion industry. By providing consumers with clear labels and a more transparent supply chain could lead to greater consumer confidence in sustainable fashion thereby creating the potential for greater growth to the sustainable fashion sector. 
Just as fair trade-type certified coffee has moved away from selling coffee based solely on an ethical premise, the fashion industry has begun to shift away from selling sustainable fashion solely based on its ethics and sustainability merits. Initially the introduction of sustainable fashion was met with design criticism, however major designers and retailers realized that sustainable fashion must stand alongside conventional fashion in design, aesthetic and accessibility. Many celebrities are placing their name behind the need for sustainable fashion. Vivienne Westwood and Stella McCartney have been long time champions of sustainable fashion and Livia Firth created the green carpet challenge, encouraging celebrities to wear sustainable fashion on the red carpet. In addition to celebrity support, a number of initiatives have emerged to promote sustainable fashion and textile production. The Better Cotton Initiative $(\mathrm{BCl})$ has attempted to address the issues of accessibility and supply of cotton by providing a secure supply chain of 'better cotton', by creating stability in the cotton production supply chain through farmer training programs.

The Better Cotton Initiative (BCl) began in 2005, with a global multi-stakeholder consultation process involving actors from along the cotton supply chain ( $\mathrm{BCl} 2011)$. From the initial consultation the $\mathrm{BCl}$ created six core components to establish their monitoring system which include: 1. Production principles and criteria to provide a global definition of 'better cotton'; 2. Farmer support to promote enabling mechanisms at both the global and local level; 3. Farm assessment encouraging farmer improvement through results and learning cycles; 4. Supply chain to connect supply and demand with identifiable 100\% 'better cotton'; 5. Monitoring, evaluating and learning to measure progress for intended impacts; 6 . Tools to function as guidelines and learning forums to facilitate exchange of best practices (BCl 2011).

Similar to the many fair trade coffee certification labels, sustainable fashion offers many certification schemes. However, fashion differs from fair trade coffee certifications, in that fashion certifications address one aspect of the supply chain. For example, fair trade certified cotton does not address labour or environmental conditions where the cotton is milled or at the factories where garments are manufactured. Similarly, a garment factory may be fair trade certified; yet the textiles manufactured may not be certified. Patagonia now offers a line of women's Fair Trade Certified clothing, however this only ensures that sewing factories are fair trade Certified, not the textiles. Patagonia plans to to incorporate Fair Trade Certified cotton into their production by 2015 (Patagonia, 2015). 
While fair trade-type certifications for coffee address both environmental and social concerns, there remains controversy over how to engage large corporate players. Similarly, sustainable fashion lacks a cohesive and widely accepted definition. Social responsibility is a complex issue for retailers where businesses may find it difficult to track and monitor the exact factory where a garment was manufactured due to multiple subcontractors used in an order. Businesses find it difficult to develop transparent reporting practices as there has yet to be an agreed upon set of standards defining sustainable fashion (Dickson, Loker \& Eckman, 2009).

The fashion industry now faces criticism in light of disasters such as Rana Plaza in April of 2013 where 1,138 garment workers lost their lives due to unsafe working conditions. The fashion industry is now doing damage control to repair the negative social and environmental implications associated with the industry. Currently 'There are not enough rules and legislation to limit pollution in the fashion supply chain, and enforcement in some jurisdictions is weak, resulting in lower retail prices for fast fashion companies (Meadows 1999, p. 36). The scope and reach of the fashion industry and its historical reliance on cheap labour to manufacture has led to intense political interest in both the developed and developing worlds. The fashion industry has been shaped by international trading agreements. The transient nature of the industry, where a garment often transcends many borders in its lifecycle, makes regulation difficult to monitor and uphold. This is where clear voluntary initiatives (VI) with clear labeling schemes can play a role in shaping the future of sustainable fashion.

Both sustainable fashion and fair trade coffee share similar issues in regard to making their respective movements' mainstream. Both the coffee industry and the fashion industry need to create consumer confidence in their labels in order to increase consumer demand. Fair trade-type coffee has seen significant gains in market availability and share since its introduction to the market in 1998; however, fair trade sales at $10 \%$ still holds only a minor portion of global coffee sales (SSI 2014). One core issue for consumers shopping for sustainable fashion is a lack of awareness of the environmental impacts of the fashion industry. A clear label linked with educational information for consumers could lead to greater consumer awareness. As consumers cited a fear of 'greenwashing' by retailers, a third party certified model could lead to greater consumer confidence. In addition, a clear label that addresses the entire lifecycle could lead to greater consumer confidence and a greater understanding of the environmental impacts of fashion. 


\subsection{Retailer Collaboration}

Following the coffee crisis in 2000, the coffee industry, through unprecedented stakeholder collaboration, came together with ICO to form the Sustainable Coffee Partnership. The proposals resulting from the partnership later gave way to the establishment of the State of Sustainability Initiatives (SSI Review 2014). Following the collapse of Rana Plaza, the fashion industry has seen an increase in stakeholder collaboration. In order for the fashion industry to follow suit, sustainable fashion must be 'co-created' (Cataldi, Dickson \& Grover, 2013). Historically, the fashion industry has operated as a secretive, protective industry based on competition. In order for sustainable fashion values to grow, values should be co-created from industry players within to provide guidance for emerging designers and brands (Cataldi, Dickson \& Grover, 2013). NIKE is attempting to do this through their Apparel Design Tool and Making It App.

The Sustainable Apparel Coalition (SAC), created by a number of large retailers, including Adidas, Gildan, H\&M, Inditex and NIKE is attempting to address sustainability and social issues throughout the fashion supply chain. The industry led initiative tackles both sustainability and social concerns in textiles and footwear. The SAC created the Higg Index, an indicator based assessment tool for best practices and sustainability performance in apparel and footwear (Sustainable Apparel Coalition, 2014). The tool was a collaborative process based on the Eco Index and Nike's Apparel Environmental Design Tool and the Global Social Compliance Tool. The Higg Index was updated to the Higg Index 2.0, and now tests the entire life-cycle of a garment right to end of use. This standard was developed to help businesses and organizations standardize how they measure and evaluate both social and environmental performances across the supply chain (SAC, 2014). The SAC provides a starting point for the sustainable fashion industry through a collaboration of large retailers working to create tools to measure sustainability and labour practices. Currently, the Higg Index is a self-monitoring tool without a consumer-facing label.

Fair trade certification schemes distinguish themselves from other social movements and labels through their breadth in addressing both social and environmental concerns and tackle trade issues along with productions conditions (Raynolds, 2009). Fair trade offers a third party verification for brands and a consumer-facing label. The success of the Fair trade movement has come to symbolize a counterpoint to the socially and environmentally destructive characteristics of the food system (Raynolds, 2009). However, the rising popularity of the movement has placed pressure on the once alternative movement to become embedded in the mainstream market by engaging with large retailers thus incorporating 
standard business norms and practices (Reynolds, 2009). Fair trade is not promoted on health benefits, but rather the benefits created for producers through environmental stewardship and equity. Fashion must rely on this type of messaging as fashion is not directly linked to health in the consumer's mind. Like fair trade coffee, sustainable fashion must rely on creating a connection between consumer and producer while highlighting the impacts along the supply chain in order to be successful.

Fair trade involves complex and often contradictory projects involving a multitude of stakeholders pursuing varying objectives. Creating a label for fashion represents an even more complex supply chain with a greater number of stakeholders, thus making the issue of adopting a voluntary initiative or labeling scheme that much more difficult to implement. Below, figures 7 and 8 outline the coffee and the cotton supply chain from production to consumption.

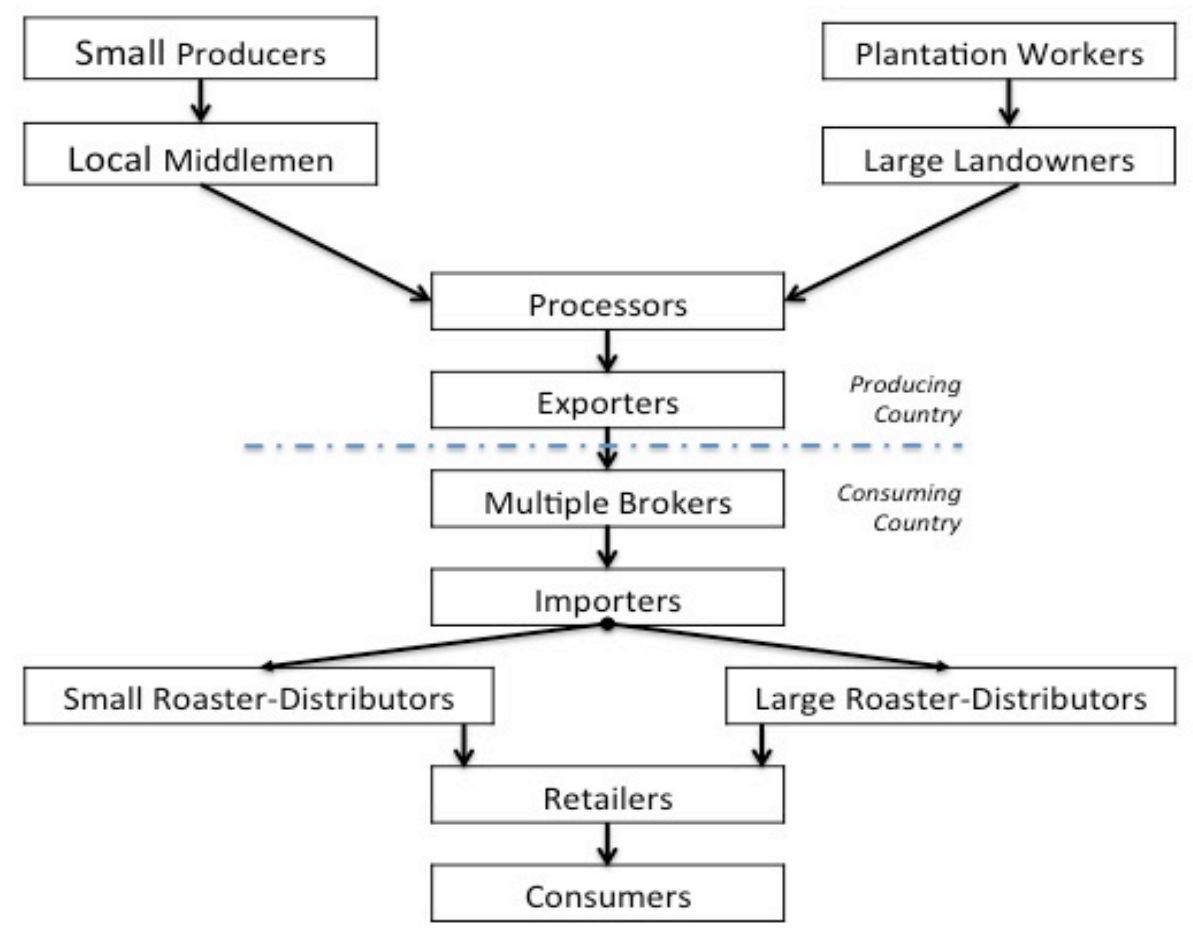

Conventional Coffee Commodity Chain (Waridel 2002; Locke, Reavis, Cameron 2010)

Figure 6 Coffee Supply Chain. Waridel 2002; Locke, Reavis \& Cameron, 2010 


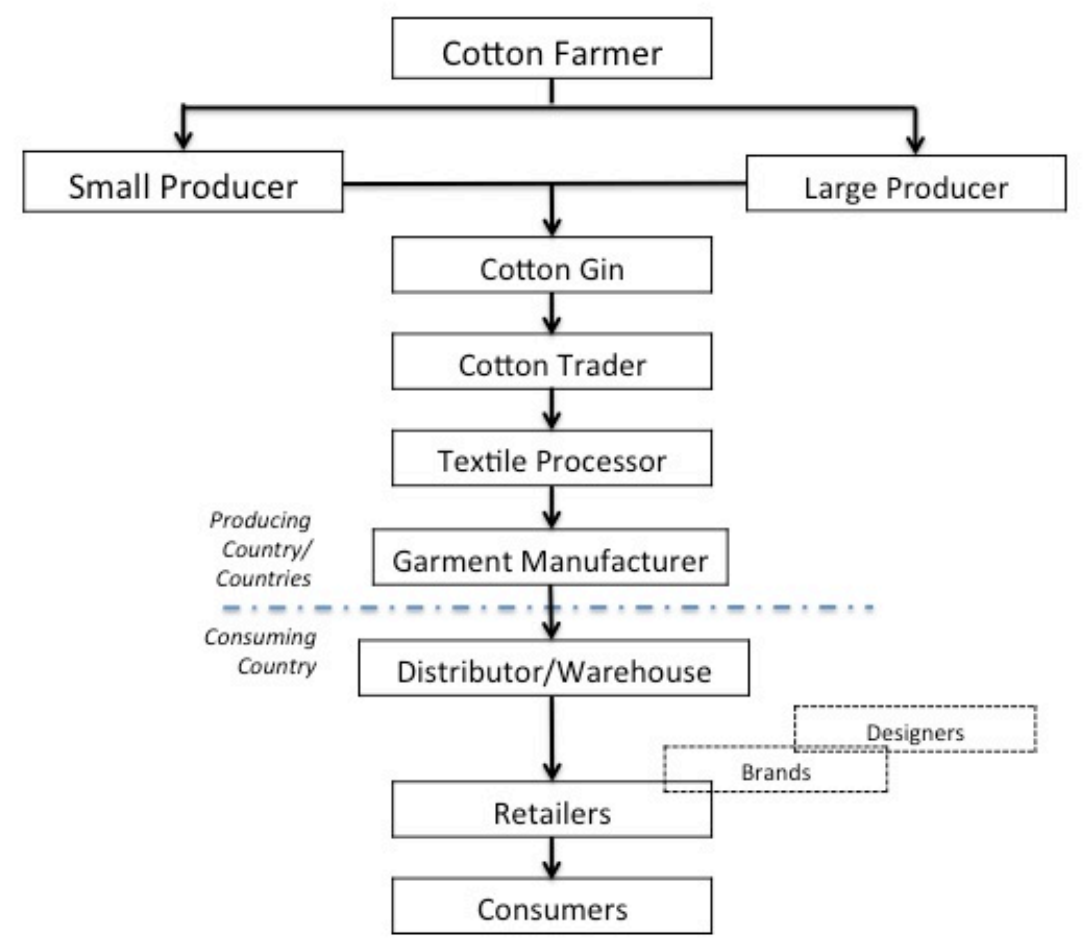

Cotton Production Supply Chain

Figure 7 Source, Author: Cotton Supply Chain

This key element of creating a more direct connection between consumers and producers is lacking in the fashion industry. The fashion industry lacks clear and cohesive labeling to incite consumer confidence (Gam, 2007). Fair trade-type certification schemes for coffee have offered that connection for consumers. By contrast, to date the fashion industry has yet to implement or to offer a mainstreamed certification scheme or label to generate widespread consumer confidence among fashion consumers. The SAC's Higg Index 2.0 offers a good start, but lacks third party verification and a trusted consumer-facing label. A number of additional voluntary initiatives and labels exist specifically for the fashion industry including the Better Cotton Initiative (BCI), MADE BY, Water<less, Organic, Eco Label, Cradle to Cradle Certification and NICE. Depending who you ask, there are over 300 eco labels for the fashion industry. Despite this, there is an inconsistency among measurement, criteria and word usage used to define sustainable fashion. 
As a result consumers lack confidence in labels and certifications regarding the fashion industry. As noted earlier, the Fair trade label (both FLO and TransFair) has taken root in the fashion industry through Patagonia, MEC, Oliberte and other small scale designers. However, fair trade certification in the fashion industry applies to only part of the supply chain. Oliberte has certified their shoe factory in Ethiopia, but does not use fair trade certified products.

\subsection{Voluntary Initiatives for Coffee and Fashion}

There exist a multitude of certification schemes and labels for both coffee and cotton. Table 12 outlines four of the most prominent fair trade-type certification labels in the coffee industry; Fair Trade (FLO), 4C Association, Rainforest Alliance Sustainable Agriculture Network (RA/SAN) and UTZ Certified. These four initiatives represent four of the largest and fastest growing fair trade-type coffee certifiers on the market, representing $75 \%$ of fair trade-type certified coffee produced globally (SSI Review 2014). These

four initiatives will be compared based on their mission, history, commercial conditions, supply chain traceability, certification method, and consumer communication and retail involvement.

\begin{tabular}{|c|c|c|c|c|}
\hline & FLO & 4C Association & RA/SAN & UTZ Certified \\
\hline Mission & $\begin{array}{l}\text { Poverty reduction } \\
\text { for developing } \\
\text { countries producers. } \\
\text { Ensure equitable } \\
\text { trading } \\
\text { arrangements for } \\
\text { disadvantaged small } \\
\text { producers who are } \\
\text { organized in } \\
\text { cooperatives. }\end{array}$ & $\begin{array}{l}\text { Guiding the } \\
\text { mainstream coffee } \\
\text { sector toward more } \\
\text { sustainable } \\
\text { production where all } \\
\text { relevant } \\
\text { stakeholders are able } \\
\text { to participate. } \\
\text { Improve the } \\
\text { economic, social and } \\
\text { environmental } \\
\text { conditions of coffee } \\
\text { production and } \\
\text { processing. }\end{array}$ & $\begin{array}{l}\text { Promote social and } \\
\text { environmental } \\
\text { sustainability in the } \\
\text { agriculture sector by } \\
\text { developing } \\
\text { standards and } \\
\text { supplying technical } \\
\text { support. Coalition of } \\
\text { independent, mostly } \\
\text { Southern non-profit } \\
\text { conservation } \\
\text { organizations. }\end{array}$ & $\begin{array}{l}\text { Create a world } \\
\text { where sustainable } \\
\text { farming is the } \\
\text { norm. Enable } \\
\text { farmers to improve } \\
\text { farming methods, } \\
\text { working conditions } \\
\text { and environmental } \\
\text { conditions. }\end{array}$ \\
\hline History & $\begin{array}{l}\text { Movement began in } \\
1970 \text { s. FLO officially } \\
\text { founded in in } 1997 \\
\text { as umbrella group } \\
\text { operating across } 120 \\
\text { countries. }\end{array}$ & $\begin{array}{l}\text { Founded in } 2006 \text {, } \\
\text { operating in } 22 \\
\text { countries. }\end{array}$ & $\begin{array}{l}\text { Founded in } 1997 \\
\text { operates in } 43 \\
\text { countries in the food } \\
\text { and agriculture } \\
\text { sector. }\end{array}$ & $\begin{array}{l}\text { Founded in } 2002, \\
\text { operating in food } \\
\text { and agriculture } \\
\text { sector across } 33 \\
\text { countries. }\end{array}$ \\
\hline
\end{tabular}




\begin{tabular}{|c|c|c|c|c|}
\hline $\begin{array}{l}\text { Commercial } \\
\text { Conditions }\end{array}$ & $\begin{array}{l}\text { Pre-financing and } \\
\text { long-term } \\
\text { relationship for } \\
\text { producers with the } \\
\text { guarantee of Fair } \\
\text { trade premium. }\end{array}$ & $\begin{array}{l}\text { Prepares producers } \\
\text { for eventual } \\
\text { compliance with } \\
\text { other consumer- } \\
\text { facing initiatives. }\end{array}$ & $\begin{array}{l}\text { Member based } \\
\text { initiative. Rainforest } \\
\text { Alliance and SAN } \\
\text { offer } 3^{\text {rd }} \text { party } \\
\text { approach to } \\
\text { standards } \\
\text { development, } \\
\text { conformity and } \\
\text { marketing. }\end{array}$ & $\begin{array}{l}\text { Strategic balance } \\
\text { between supply } \\
\text { and demand. } \\
\text { Premium } \\
\text { dependent on } \\
\text { market. }\end{array}$ \\
\hline $\begin{array}{l}\text { Supply Chain } \\
\text { Traceability }\end{array}$ & $\begin{array}{l}\text { Producer level } \\
\text { focused. Trader } \\
\text { standards } \\
\text { applicable. }\end{array}$ & $\begin{array}{l}\text { Models of identity } \\
\text { preservation, mass } \\
\text { balance and } \\
\text { segregation applied } \\
\text { along the supply } \\
\text { chain. } \\
\text { License/certificate } \\
\text { must be passed up } \\
\text { along with the } \\
\text { product to the final } \\
\text { buyer level. }\end{array}$ & $\begin{array}{l}\text { Standards focused at } \\
\text { producer level. }\end{array}$ & $\begin{array}{l}\text { Inspection levels } \\
\text { offer a separate } \\
\text { chain of custody } \\
\text { code. Allows for } \\
\text { high traceability. }\end{array}$ \\
\hline $\begin{array}{l}\text { Certification } \\
\text { Method }\end{array}$ & $\begin{array}{l}\text { Separate } \\
\text { certification process } \\
\text { through FLO-Cert } \\
\text { (Bonn, Germany). } \\
\text { Ensures producers } \\
\text { and traders comply } \\
\text { with standards. Full } \\
\text { re-assessment every } \\
3 \text { years. }\end{array}$ & $\begin{array}{l}\text { Required to submit } \\
\text { self-assessments and } \\
\text { undergo verification } \\
\text { audits by } 3^{\text {rd }} \text { party } \\
\text { auditors. }\end{array}$ & $\begin{array}{l}\text { SAN is the standard } \\
\text { setting body for } \\
\text { Rainforest Alliance } \\
\text { Certified Agriculture } \\
\text { products. All audits } \\
\text { by third party } \\
\text { auditors, all units } \\
\text { certified every } 3 \\
\text { years. }\end{array}$ & $\begin{array}{l}\text { Third party } \\
\text { auditors certify all } \\
\text { UTZ units yearly. }\end{array}$ \\
\hline $\begin{array}{l}\text { Consumer } \\
\text { Communication }\end{array}$ & $\begin{array}{l}\text { Business to } \\
\text { Consumer (B2C) with } \\
\text { active } \\
\text { communication. }\end{array}$ & $\begin{array}{l}\text { Business to business } \\
\text { (B2B) }\end{array}$ & B2C & $\begin{array}{l}\text { B2C. UTZ label } \\
\text { used when product } \\
\text { is } 90 \% \text { UTZ } \\
\text { certified. }\end{array}$ \\
\hline $\begin{array}{l}\text { Retailer } \\
\text { involved }\end{array}$ & $\begin{array}{l}\text { Starbucks, Camino, } \\
\text { Dark Horse }\end{array}$ & $\begin{array}{l}\text { Umbrella } \\
\text { organization-UTZ, } \\
\text { RA/SAN, Fair Trade }\end{array}$ & Second Cup & IKEA \\
\hline
\end{tabular}

Table 12 Source, Author. Fair trade type certification for the coffee industry

Table 13 outlines four of the most prominent fair trade-type certification labels in the cotton industry;

Fair Trade (FLO), International Federation of Organic Agriculture Movements (IFOAM), Cotton Made in

America $(\mathrm{Cmi} A)$ and Better Cotton Initiative $(\mathrm{BCl})$. These four cotton initiatives represent considerable

market share. These four initiatives will be compared based on their mission, history, commercial conditions, supply chain traceability, certification method, consumer communication and retail involvement. 


\begin{tabular}{|c|c|c|c|c|}
\hline & FLO & IFOAM & CmiA & $\mathrm{BCl}$ \\
\hline Mission & $\begin{array}{l}\text { Poverty reduction } \\
\text { for developing } \\
\text { countries producers. } \\
\text { Ensure equitable } \\
\text { trading } \\
\text { arrangements for } \\
\text { disadvantaged small } \\
\text { producers who are } \\
\text { organized in } \\
\text { cooperatives. }\end{array}$ & $\begin{array}{l}\text { Change the way the } \\
\text { world sees } \\
\text { agriculture by } \\
\text { making organic } \\
\text { agriculture popular } \\
\text { and affordable, } \\
\text { enabling organic to } \\
\text { compete with large } \\
\text { agribusiness. }\end{array}$ & $\begin{array}{l}\text { Limit the impact } \\
\text { cultivating cotton has } \\
\text { on people and the } \\
\text { environment. } \\
\text { Improve social, } \\
\text { economic and } \\
\text { environmental } \\
\text { condition of } \\
\text { smallholder farmers } \\
\text { through sustainably } \\
\text { produced cotton. }\end{array}$ & $\begin{array}{l}\text { Provides a holistic } \\
\text { approach to } \\
\text { building and } \\
\text { implementing } \\
\text { sustainability in } \\
\text { cotton production. } \\
\text { Improve livelihoods } \\
\text { and economic } \\
\text { development in } \\
\text { cotton producing } \\
\text { areas. }\end{array}$ \\
\hline History & $\begin{array}{l}\text { Movement began in } \\
\text { 1970s. FLO officially } \\
\text { founded in in } 1997 \\
\text { as an umbrella group } \\
\text { operating across } 120 \\
\text { countries. }\end{array}$ & $\begin{array}{l}\text { Founded in } 1972 . \\
\text { Umbrella } \\
\text { organization } \\
\text { operating in food } \\
\text { and agriculture } \\
\text { business sector } \\
\text { across } 116 \text { countries. }\end{array}$ & $\begin{array}{l}\text { Founded in } 2005 . \\
\text { Operating in six } \\
\text { countries throughout } \\
\text { Africa. }\end{array}$ & $\begin{array}{l}\text { Founded in } 2005 . \\
\text { Operating in } 8 \\
\text { countries. }\end{array}$ \\
\hline $\begin{array}{l}\text { Commercial } \\
\text { Conditions }\end{array}$ & $\begin{array}{l}\text { Pre-financing and } \\
\text { long-term } \\
\text { relationship for } \\
\text { producers with the } \\
\text { guarantee of Fair } \\
\text { trade premium. }\end{array}$ & $\begin{array}{l}\text { Primary revenue } \\
\text { from fees and } \\
\text { services. }\end{array}$ & $\begin{array}{l}\text { Focuses on driving } \\
\text { both market and } \\
\text { supply chain uptake } \\
\text { of sustainable cotton } \\
\text { of international } \\
\text { textile companies. }\end{array}$ & $\begin{array}{l}\text { Creates stability in } \\
\text { supply chain of } \\
\text { sustainable cotton } \\
\text { to create stability } \\
\text { for both producer } \\
\text { and purchaser }\end{array}$ \\
\hline $\begin{array}{l}\text { Supply Chain } \\
\text { Traceability }\end{array}$ & $\begin{array}{l}\text { Producer level } \\
\text { focused. Trader } \\
\text { standards applicable. }\end{array}$ & $\begin{array}{l}\text { IFOAM operates as } \\
\text { an association of } \\
\text { standards uniting } \\
\text { organic stakeholders, } \\
\text { advocates and } \\
\text { facilitates organic } \\
\text { development and } \\
\text { provides training. } \\
\text { Develops standards } \\
\text { to ensure sustainable } \\
\text { agriculture practices } \\
\text { among members. }\end{array}$ & $\begin{array}{l}\text { Develops standards, } \\
\text { verifying compliance } \\
\text { methods and } \\
\text { marketing labels. }\end{array}$ & $\begin{array}{l}\text { Develops standards } \\
\text { and verifying } \\
\text { compliance with } \\
\text { standards to } \\
\text { ensure sustainable } \\
\text { cotton production } \\
\text { among suppliers. }\end{array}$ \\
\hline $\begin{array}{l}\text { Certification } \\
\text { Method }\end{array}$ & $\begin{array}{l}\text { Separate } \\
\text { certification process } \\
\text { through FLO-Cert } \\
\text { (Bonn, Germany). } \\
\text { Ensures producers } \\
\text { and traders comply } \\
\text { with standards. Full } \\
\text { re-assessment every } \\
3 \text { years. }\end{array}$ & $\begin{array}{l}\text { Membership based. } \\
\text { Compliant } \\
\text { enterprises must } \\
\text { undergo full } \\
\text { assessment every } \\
\text { year for } \\
\text { recertification. } \\
\text { Audits conducted by } \\
\text { accredited } 3^{\text {rd }} \text { party } \\
\text { auditors. }\end{array}$ & $\begin{array}{l}\text { Initial approval based } \\
\text { on self-declaration. } \\
\text { Third party } \\
\text { verifications every } \\
\text { two years to verify } \\
\text { compliance. }\end{array}$ & $\begin{array}{l}\text { Yearly verification } \\
\text { by third party } \\
\text { auditors. }\end{array}$ \\
\hline Consumer & Business to & $\mathrm{B} 2 \mathrm{C}$ & B2C. Marketing label & B2B. \\
\hline
\end{tabular}




\begin{tabular}{|c|c|c|c|c|}
\hline & FLO & IFOAM & CmiA & $\mathrm{BCl}$ \\
\hline Communication & $\begin{array}{l}\text { Consumer (B2C) with } \\
\text { active } \\
\text { communication. }\end{array}$ & & $\begin{array}{l}\text { to ensure compliance } \\
\text { among members. }\end{array}$ & \\
\hline $\begin{array}{l}\text { Retailer } \\
\text { involved }\end{array}$ & Patagonia, MEC & $\begin{array}{l}\text { Nike, Adidas, H\&M, } \\
\text { Inditex }\end{array}$ & Gildan & $\begin{array}{l}\text { Adidas, H\&M, } \\
\text { Iditex, Nike }\end{array}$ \\
\hline
\end{tabular}

Table 13 Source, Author. Fair trade-type certification labels for the cotton industry.

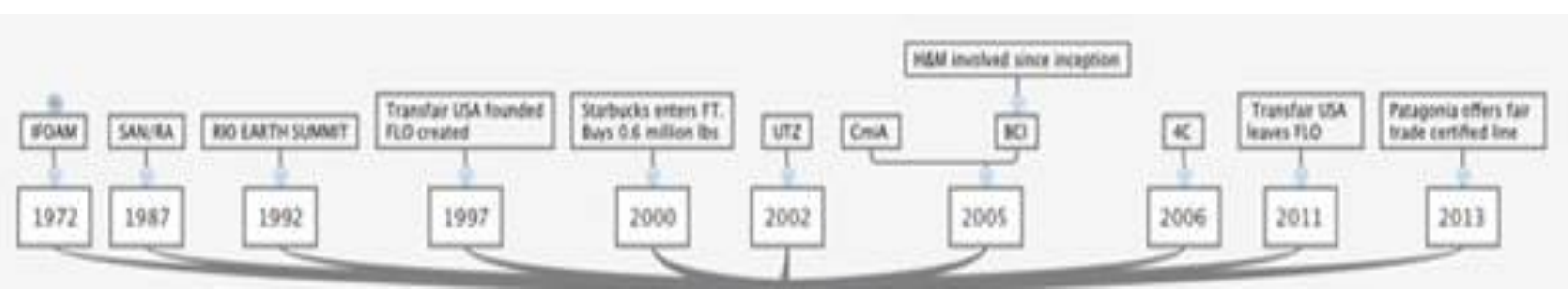

Figure 8 Timeline of voluntary initiatives in cotton and coffee industry.

The timeline above shows the evolution of voluntary initiatives for both coffee and cotton. IFOAM was the first registered certification in 1972 , followed by SAN/RA in 1987. FLO was officially registered as a VI in 1997. Both CmiA and $\mathrm{BCl}$ began in 2005, with $\mathrm{H} \& \mathrm{M}$ partnering with $\mathrm{BCl}$ from the beginning. In 2013, fair trade certified cotton became available at Patagonia.

\subsection{Learning Lessons from Fair Trade:}

It is not likely that Fair trade certification, or any labeling scheme, alone will completely transform markets to the point where people and the environment are at the center of production, trade and consumption (Taylor, 2004). Instead, change requires attention and action both formally and informally to show mainstream logics and practices can shift organizational trajectories over time. Labeling and certification play an important role in this shift toward more sustainable industries, but require the involvement of large retail actors. However, these large retail actors in the Fair trade movement could serve to undermine the very logic and practices set out by Fair trade in the first place. Taylor (2004) argues that the use of large-scale retail actors highlights the issue of supply and demand at a rate suitable for large retailers. However, as stated in Chapter 4, production numbers demonstrate that fair trade-type certified coffee (or compliant coffee) far exceeds its sales.

Fair trade's biggest challenge comes from the rise of market driven corporate buyers, such as Starbucks and Nestle. Fair trade has attempted to embed itself in the market exchange within a system of social and moral relations. As the movement has continued to grow and attract corporate support it now 
continues to attempt to push back against the same market it has penetrated. Certifications like Fair trade are gaining attention worldwide with their promise to create consumption change. Labels stress the importance of shifting the market paradigm to walk the line of globalization by placing markets first and prioritizing people and development (Taylor 2004). Fair trade's capacity to effect change in the market and throughout different industries, relies on it moving away from niche markets to more mainstream markets. Fashion, as an industry, can learn from this model as it shifts into larger retailers such as Patagonia.

However, this shift away from niche markets to incorporation of larger retailers and multinationals must function as a hybrid '...simultaneously a social movement and an alternative market structure' (Jaffee, 2012, p.1). Fair trade-type models for both coffee and fashion must operate within the logic of market capitalism yet function as an alternative to unequal economic relations surrounding conventional trade. In order to properly function, the Fair trade model must use structures of the market it seeks to alter. Large retailers have acknowledged the environmental impacts of their production, and as Chapter 4 demonstrates, retailers are increasing their reporting on sustainability measures and setting more aggressive targets to address environmental concerns along their supply chains.

The Fair trade movement faces skepticism over its partnership with large retailers and multinationals. The Fair Trade USA movement began to target larger firms following the 2000 price crash for conventional coffee. Fair Trade USA chose Starbucks, a larger specialty roaster. Starbucks was licensed under TransFair to sell both wholesale and brewed coffee at all its US stores promising to purchase 653,000 pounds in 2010, with an increase to 1 million in 2011 (Jaeffee, 2012). However, this represents below $1 \%$ of all Starbucks supplies, far below the $5 \%$ minimum fair trade requires of firms in order to use the seal. The Starbucks partnership and purchase of fair trade coffee increased the visibility of the Fair Trade brand, but created tension between Fair Trade USA and Fair Trade International. In 2012, Fair Trade USA separated from FLO and trademarked Fair Trade Certified. In order to create a sustainable certification scheme, the sustainable fashion certification labels must find a way to address these complex issues of incorporating large retailers such as Adidas, Gildan, Inditex, H\&M and NIKE.

\subsection{Barriers to Implementing CSR Practices}

Currently, there is no set standard for sustainability reporting for the fashion industry. Before a consumer-facing label can be implemented, the industry must come together to create a standard 
reporting mechanism. The SAC is attempting to create this with the help of NIKE. However, the SAC remains self-monitored. In order to become trusted by consumers, a third party monitoring for the SAC is needed.

Beyond a lack of clarity in reporting, consumers lack an awareness of the environmental impacts of fashion. NGO campaigns like the Greenpeace Detox Challenge help to create greater consumer awareness, but to date have not provided a long time media presence to engage the public. Educating consumers on sustainable fashion will be a pivotal component to making a successful VI and consumerfacing label for the fashion industry. Business development of social responsibility is difficult to implement. Consumers find it difficult to engage with sustainability and social responsibility due to a lack of clarity and access to information. Not all companies provide information into the workings of their supply chains, and often when it is presented, the information is difficult to describe (Dickson, Locker \& Eckman, 2013). As businesses are making their way to becoming more sustainable and compliant, their message can be diluted. Implementing sustainability is not black and white; rather it is a complex process involving gradual change.

\subsection{Conclusion}

Fair trade-type certification demonstrates the impact a consumer facing label engaged in education, with strong NGO support and large retail inclusion, can have on a market. Fair trade-type certifications have become relatively mainstreamed, and captured both production and market share that continue to grow each year. Fashion can learn from fair trade-type certification allowing the labeling to educate and inform consumers and for retailers to act as the proxies for consumers. Certifications and labels like fair trade gain worldwide attention with their promise to create consumption change. They stress the importance of shifting the market paradigm by placing people and the environment in the market.

Fair trade-type certification and labeling for coffee provides a holistic and cohesive view of the coffee industry, addressing both environmental and social concerns. Currently, the fashion industry lacks a cohesive label that addresses the entire supply chain. By applying lessons from fair trade compliant coffee certification, the fashion industry can look to create a label addressing its entire supply chain. The label itself will not completely transform the market; it will require retailer cooperation, consumer education and media attention. However, as consumers cite a lack of trust in sustainable claims of 
companies, a third party certified label that addresses the entire supply chain could lead to greater consumer trust and an increase in sustainable fashion purchases.

\section{Chapter 6 Role of retailers as proxies for consumers}

\subsection{Introduction}

Voluntary initiatives and awareness campaigns by NGOs may be used to generate influence beyond the direct parties involved in order to influence both producers and consumers (Webb 2004). Literature demonstrates that retailers can lead in voluntary initiatives and be positioned in a way to advocate on behalf of consumers and anticipate future demands or trends (Webb 2004). As such, retailers have the unique ability to implement or demand producers uphold voluntary codes and thus may act as 'proxies' for consumers while anticipating future trends in sustainability. It remains imperative that NGOs and retailers work together in order to create credibility for industry standards and codes (Webb 2004).

This chapter highlights the unique role retailers can play in implementing sustainability into their supply chains. Literature demonstrates the role retailers can play as proxies for consumers, by doing the research for consumers and acting on behalf of environmentally and socially responsible consumers. Large retailers with strong brand recognition may try to mitigate possible criticisms by implementing strong CSR strategies. In addition, brands look to identify upcoming trends in the industry, and may be looking to enhance their reputation as a socially and environmentally responsible brand. Following events like Rana Plaza and the negative media attention that followed, companies have struggled to reverse the negative effects with socially and environmentally irresponsible production (Park, 2006). As a result, companies looking to improve their competitiveness and improve brand reputation may look to more sustainable sourcing and production. Retailers function as proxies as they do the work for the consumers by anticipating future trends in the industry and can provide the avenue for consumers to purchase sustainably and ethically.

Chapter 4 demonstrated the sustainability initiatives the sample set of retailers have incorporated into their supply chains. The content analysis highlighted the shortcomings in the reporting structure where there is no set standards. NIKE is looking to address this by working with the SAC to improve the Higg Index so that retailers can use the same language and implement a set standard for reporting. In NIKE's 2014 CSR report, the lack of a set standard is highlighted as major issues within the fashion industry. By working the Sustainable Apparel Coalition, NIKE is actively pursuing ways to implement a set-reporting 
standard. Chapter 5 drew lesson from fair-trade type coffee certification for the fashion industry, demonstrating the role that large retailers can play in implementing voluntary initiatives and exposing consumers to initiatives and labels. This chapter will build on the role that retailers can play by highlighting two key fashion retailers that have addressed sustainability and incorporated it directly into their core business model. Patagonia and Marks \& Spencer are highlighted as two leaders in sustainable fashion. Patagonia is a sports apparel \& outdoor retailer and Marks \& Spencer (M\&S) is a fast fashion retailer.

\subsection{Patagonia}

Patagonia, founded in 1972, is an environmentally conscious outdoor apparel company, spearheaded by founder, Yvon Chouinard. As an avid outdoorsman, Chouinard started Patagonia with the explicit mission to create a company with limited impact on the natural environment with a mission to 'Build the best product, cause no unnecessary harm, use business to inspire and implement solutions to the environmental crisis' (Patagonia, 2014). However, while Chouinard holds a strong commitment to the environment, Chouinard acknowledges that Patagonia is a product-based business, and in order to make a difference, the company has to sell their products and make a profit. Patagonia demonstrates the role a retailer can play in acting as proxy for consumers by doing research for its consumers in order to provide products that are well made, functional and with a limited environmental impact. Patagonia's mission was formed around four values: quality, integrity, environmentalism, and innovation to provide products of the highest quality possible (Patagonia, 2014). In addition to acting as proxy for consumers, Patagonia has influenced leaders within the fashion industry, most notably through its use of organic cotton and Synchilla, a fleece-like material made from recycled pop bottles.

Patagonia's commitment to creating garments with a low environmental impact caused Patagonia to explore the life cycle impacts of four of their major textiles; polyester, nylon, cotton and rayon in the early 1990s. Patagonia discovered cotton generated significant environmental and social costs. As cotton accounted for $20 \%$ of Patagonia's products, Chouinard implemented a strategy to address the environmental concerns, giving managers 18 months to substitute organic cotton for conventional cotton in 1994. By 1996, Patagonia had switched all of their cotton products to organic cotton and reduced packaging throughout the company (Gardiner, 1997). However, this came at a cost to the company as Patagonia had to drop lucrative products from their collection due to their increase in price. While making the transition to organic cotton, the company realized that profit margins would have to 
be lowered. However, consumer demand for organic cotton, combined with Chouinard's commitment to the environment, were the deciding factors for the transition (Gardiner 1997). Sourcing organic cotton increased production costs by $20 \%$, but Patagonia only increased prices by $5 \%$. The risk paid off for Patagonia in the long run as cotton sales increased by 25\% in in 1996 (Little, 2011). In addition, Patagonia set the precedent for other companies in the organic cotton industry to follow suit, with Patagonia providing incentive and the business model for companies like NIKE and Walmart.

Patagonia's pollution prevention effort includes a life cycle analysis to determine how to reduce toxic waste, water and energy use. In 1993, Patagonia began manufacturing jackets from Synchilla, a fleecelike fabric made of recycled pop bottles. Patagonia was the first outdoors apparel company to use Synchilla in their product line. By 2011, Patagonia had recycled over 86 million soda bottles using Synchilla (Patagonia 2, 2014). In addition, Patagonia advocates for consumers to consume and purchase less. In 2012 for Black Friday, Patagonia launched the 'don't buy me' campaign advocating for consumers to repair their old Patagonia wear rather than buying something new.

Patagonia demonstrates that a commitment to the environment can be economically feasible and beneficial for a brand's identity as the company grossed 154 million US in 1995 (Gardiner 1997), with sales increasing each year, with 600 million in revenues in 2013 (Patagonia 3, 2014). At the core of Patagonia is a commitment to the environment, with preventative measures integral to their environmental standards. Patagonia commits $1 \%$ of their profit or $10 \%$ of their sales (whichever is more) to environmental organizations. Since 1985, they have donated over \$25 million to over 1,000 organizations (Patagonia 3, 2014). In 2001 Chouinard co-founded 1\% for the Planet, an alliance for businesses like Patagonia who commit $1 \%$ of their profits to the environment. Since its inception, over 1,477 members worldwide donate $\$ 15$ million annually to over 2,000 organizations (Patagonia 3, 2014).

Patagonia's commitment to the environment extends beyond materials to include energy efficiency and transparency. Patagonia audited their facilities resulting in installing energy efficient lighting and installing skylights and advanced heating and cooling technologies leading to a $25 \%$ increase in energy savings (Lutz, 2011). In 2005 Patagonia installed its first solar PV system on a facility at its offices in Ventura. In order to increase accountability, Chouinard stresses transparency throughout its supply chain to include social standards. As a way to create greater consumer confidence in their sustainability 
and social claims, Patagonia publishes its annual factory list so that NGOs, customers and governments can easily monitor environmental and social impacts of its garments.

Patagonia's mission is rooted in creating apparel with limited environmental impacts. Chouinard understands that in order to be successful, Patagonia must create products that are well made and sustainable. Chouinard embeds sustainability throughout the entire process, from the materials used, the energy efficiency of Patagonia facilities, employee engagement to consumer consumption and disposal. Patagonia encourages employees to suggest environmental initiatives. Patagonia has faced challenges in incorporating sustainability throughout their entire supply chain, however, each time the company made the decision to implement processes to improve their environmental commitments, they paid off financially.

Patagonia demonstrates the role a retailer can play, both in acting as proxy for consumers and in influencing other brands. Patagonia's commitment to the environment, particularly to sustainable cotton, has led to others in the industry following suit. Patagonia's culture of environmental and social consciousness is rooted in Chouinard's belief in sustainability. Patagonia's success is rooted in its founder's core beliefs, quality apparel and strong marketing. Patagonia offers indication that there exists a business case for sustainable fashion.

\subsection{Marks \& Spencer}

Marks \& Spencer (M\&S) is a UK based retailer of own-brand clothing, home products and quality food with 1253 stores worldwide serving over 33.6 million customers in the UK. M\&S has embedded sustainability directly into their core mission and makes claims of being the most sustainable retailer. To address environmental and social concerns, M\&S has partnered with NGOs like WWF, Oxfam and UNICEF to create programs and initiatives addressing sustainability throughout their supply chain. In2007, M\&S launched Plan A, the retailer's sustainability program with the help of WWF. The program addresses both social and environmental concerns throughout the supply chain of clothing, home products and food. Plan A incorporates four main pillars; Inspiration, Intouch, Integrity and Innovation. Each is used to engage with consumers and suppliers on sustainability. Since its 2007 launch, M\&S has improved energy efficiency by $25 \%$, cut waste by $34 \%$, addressed the sustainability of raw materials (such as cotton) and increased its work on ethical trade (M\&S, 2014). 
Plan A lists 100 commitments to address material impacts generated throughout their supply chain. In 2013, M\&S achieved 9 of its commitments, is on target for 79 and behind/not started on 12 commitments. One of their most ambitious initiatives is to have a sustainability credential attached to $50 \%$ of its products by 2015 , and to $100 \%$ of its products by 2020 . Among the sustainability credentials is sustainable cotton sourcing, green factory programs and recycling partnerships. M\&S became the world's largest purchaser of organic cotton in 2010, and by 2013, M\&S sourced $20 \%$ of its cotton from sustainable sources including $\mathrm{BCl}$, Fair trade, organic and recycled (Plan $\mathrm{A}, 2014$ ). In addition, M\&S has incorporated fair sourcing into its supply chain, and is pursuing a Factory Ethical Excellence initiative to train 500,000 supply chain workers. Training will include support for disadvantaged small producers and education on worker rights.

To address the lifecycle of its clothing, M\&S partnered with Oxfam to introduce its 'Shwopping program'. M\&S encourages customers to bring in their used clothing to participating M\&S stores, where it will be donated to UNICEF to resell online, in their stores or in international markets (M\&S, 2014). What is not sold will be recycled, with high-end materials made into new fabrics and low quality materials used for stuffing. Since initiating the 'Shwopping' program, over 7.8 million garments, at an estimated $£ 5.5$ million have been donated to Oxfam.

M\&S functions as a proxy for consumers by advocating for sustainability and equality to its customers and other organizations. M\&S partnered with UNICEF in 2013 to create a hanger-recycling program. The hanger recycling program encourages consumers to leave their hangers at the till when they pay, allowing M\&S to recycle and reuse the hangers, saving the company money. In 2013, M\&S recycled 152 million hangers, saving 15,000 tonnes of $\mathrm{CO}$, and donated $57 \mathrm{p}$ for reach box of hangers recycled M\&S 2 , 2014). M\&S has set a target to recycle 200 million hangers each year, donating a minimum of $£ 650,000$ per year for the next three years to UNICEF. M\&S and UNICEF are directing the money to a pilot program in Bangladesh, working in communities to improve health care, access to water and ensuring education (M\&S 2, 2014). In addition, M\&S partnered with UNICEF UK ambassador and celebrity Cat Deeley to promote their hanger-recycling program and engage with UK consumers.

$M \& S^{\prime}$ success as a sustainable retailer extends beyond fashion to its food and home products line. M\&S has made it their mission to set a standard for sustainable and ethical sourcing. As a result of their 
ambitious Plan A, M\&S has received over 100 sustainability awards and is recognized as a sustainability leader (M\&S, 2014).

\subsection{Conclusion}

Patagonia and M\&S demonstrate the influence retailers can have on other industry players and on their customers. Due to their market success as sustainable retailers, Patagonia and M\&S are in a position to be influential for other private sector players. Both Patagonia and M\&S have high level management invested in their sustainable initiatives to make sure environmental sustainability is at the core of their business practices. Both M\&S and Patagonia address supply chain issues, and work toward providing greater transparency throughout their supply chain. Both Patagonia and M\&S have acted as proxies for consumers by providing clothing that is sustainable. Additionally they have acted as innovators in their industry to encourage other retailers to follow suit. Patagonia was the first apparel retailer to introduce Synchilla to their line and incorporate $100 \%$ organic cotton into their supply chain, establishing an organic cotton industry to act as a model for companies like NIKE, H\&M and Walmart (Gardiner, 2011). In addition, Patagonia uses consumers facing labels, and currently sources Fair Trade Certified cotton and it produces a line of clothing in Fair Trade Certified factories.

In order to address sustainability issues and instill greater awareness and trust in their sustainability claims, M\&S and Patagonia have partnered with NGOs like $\mathrm{BCl}$ to source better cotton. M\&S and Patagonia understand the value of marketing their sustainability issues to their consumers. M\&S has strategically partnered with NGOs and celebrities to engage with their consumers on aspects of sustainability. Patagonia has launched campaigns encouraging their customers to fix their old Patagonia gear rather than buying new gear. By partnering with NGOs to incorporate VIs that are well marketed and promoted, Patagonia and M\&S are well positioned to influence both producers and consumers.

Retailers have the unique opportunity to act as proxy for their consumers, Patagonia and M\&S demonstrate that incorporating sustainability into core business actions can be financially beneficial for a company. By incorporating sustainability into their supply chains, Patagonia and M\&S are positioned to act on behalf of their consumers to provide sustainability options and anticipate future trends (Webb, 2004). M\&S and Patagonia have integrated sustainability into the core of their businesses, advocating for greater transparency and accountability throughout their supply chains. In doing so, both are placing greater pressure on retailers to follow suit. 


\section{Chapter 7 Conclusion \& Recommendations}

\subsection{Findings}

Historically, the fashion industry has acted on the spectrum of weak sustainability with greater emphasis placed on economic performance. A greater acceptance and acknowledgement of the negative impacts the industry has on both society and the environment can aid in shifting away from the current conventional model (Giddings, Hopwood \& O'Brian, 2002). Literature demonstrates that there are considerable negative environmental and social impacts generated throughout the fashion supply chain, in the production of textiles, the manufacturing of garments and in the consumer and disposal phase.

The traditional fashion industry supply chain emphasizes economic gain and transactional relationships where success is placed on economic drivers and performances. The fashion industry has benefited from the globalized and fragmented supply chain, allowing brands to avert direct responsibility through subcontracting their manufacturing abroad. Fast fashion is the latest manifestation of the fashion model, accelerating the negative environmental and social impacts of the industry. However, due to increasing consumer awareness through media coverage and NGO campaigns, retailers are increasingly being held accountable for garments throughout the entire production lifecycle. As a result, sustainable fashion is becoming an increasingly popular topic, with most retailers releasing yearly CSR reports tracking their environmental and social progress.

While globalization has led to a diversification of the fashion industry, it also allows for consumers to be more engaged with the brands they buy, including understanding their supply chains. NGOs can use the increase in communication to their advantage by using social media to educate consumers on the impacts of the fashion industry. Following the collapse of Rana Plaza in 2013, pictures of the tragic collapse made their way around the world. NGO and media campaigns engaged with and educated consumers on the impacts of the industry. In response, NGO campaigns were able to place increased pressure on companies to respond and address social concerns where their garments were made.

There exists clear academic recognition on the need to integrate the economy, society and environment to create a sustainable fashion industry, yet there exists little guidance on how this can be achieved in theory and practice (Giddings, Hopwood \& O'Brian, 2002). As the study demonstrates, incorporating sustainability into the supply chain and a slowing down of production can function to create tangible 
benefits for the brands including safer and cleaner facilities, reduced environmental and health risks and an improvement in product quality (Giddings, Hopwood \& O'Brian, 2002). In addition, sustainable initiatives can create positive PR for brands. For example, in 2011 H\&M launched its Conscious Collection integrating organic cotton, recycled polyester and tencel. H\&M claims to be a leader in sustainable fashion and uses their actions to generate PR. Adopting sustainability also creates competitive advantage for firms to move ahead of regulations and shows a firms due diligence.

As demonstrated in Chapter 4, CSR reports are the industry norm, with reports becoming more detailed each year. Leading retailers are reporting on sustainability, with water, waste, CO2 and energy listed as high priority. Despite the lack of a clear industry standard and cohesive monitoring, trends in sustainability have emerged in the fashion industry. Across the sector, the material sourcing phase was highlighted as contributing the greatest environmental impacts. Each of the sample set of retailers has adopted measures to address the issues presented through textile production, specifically in regards to cotton. Furthermore, retailers highlighted the impacts generated in the consumer phase. To address this, retailers have begun to adopt take-back programs in order to recycle or reuse used garments.

\subsection{Harmonizing Voluntary Initiatives}

Literature emphasizes the shortcomings of existing voluntary initiatives in the fashion industry due to their lack of cohesiveness and lack of consumer recognition. Regulations/laws can be difficult to implement at an international level due to the long supply chain of fashion, often traversing multiple borders in its manufacturing phase. Through VIs or certification schemes, retailers can demand transparency from their suppliers throughout their supply chains to ensure sustainability is embedded throughout the entire life cycle of a garment. A clear V.I. with an embedded certification model can communicate to consumers through a trusted labeling scheme. However, there currently does not exist a comprehensive scheme for supplier factories to adopt, one that addresses the entire lifecycle and scope of fashion.

There exist many VIs for the fashion industry, many with overlap in their content and standards. However, these VIs often have different standards of reporting and monitoring, which can act in conflict with each other (Newitt, 2013). While there is growing awareness among retailers and NGOs alike on the impacts of the fashion industry, this has yet to lead to a consensus around CSR activities and objectives for the fashion industry. Supplier factories often complain of the multitude of standards and 
codes, which can lead to audit fatigue and high costs, specifically when codes overlap in content but differ in reporting mechanisms (Newitt, 2013). The contradictory monitoring and reporting of these standards can serve to impede progress, and discourage factory suppliers from complying due to cost or lack of time.

Due to the fashion industry's global reach, spanning many jurisdictions, regulations are difficult to implement, monitor and enforce (Gam, 2007). Strict voluntary initiatives that focus on raising consumer awareness, thereby creating greater demand for eco fashion have greater potential to lead to reform within the fashion industry. To do so, voluntary initiatives must include clear labeling of 'eco' products and designer input, and include strict guidelines for company and designer standards. Standards must take the entire life cycle of a garment into consideration. Furthermore, a voluntary initiative must address social and ethical concerns generated throughout the supply chain. A comprehensive VI must include both strict environmental and social standards. Fashion can apply lessons from the fair trade coffee industry by appealing to consumers based on ethics and environmental responsibility through a trusted consumer-facing label. Fair trade was successful, in part, due to their recognizable label. Fair trade type certifications are most often business to consumer facing and provide consumers with the environmental and social information on the benefits of purchasing fair trade. Fair trade certification models have capitalized on large retailer involvement, allowing certifications to become mainstreamed and therefore more accessible for consumers.

There continues to be a lack of consumer awareness regarding the negative environmental and social impacts of the clothing industry. With the shift towards fast fashion these environmental and social impacts have been exaggerated. While recycling and the acceptance of organic have become more mainstreamed in the food industry, this has yet to be translated to the fashion/apparel sector. Consumer awareness and education campaigns are key to success of a comprehensive V.I. Education on the negative impacts on both producers and the planet generated during the manufacturing phase is needed, in addition to placing onus on consumers to properly care for clothing and dispose of garments properly. Brands like H\&M are attempting to educate consumers through their responsible care labels, but this has yet to extend to their lifecycle assessments. H\&M continues to make garments made quickly and affordably, garments that are designed to be worn for a season and discarded. Sustainability must be thought of throughout the entire supply chain, by creating clothing made environmentally and social responsible, and designed to last. 
Research demonstrates that 'green' methods adopted for the manufacturing of cotton can prove to be beneficial for the apparel industry, consumers and the environment alike (Moore, 2004). A sustainable supply chain of organic cotton can lead to greater stability for producers and manufacturers alike leading to improvements in social and environmental standards. $\mathrm{BCl}$ is attempting to create that stable cotton supply chain and has partnered with many large retailers including H\&M, NIKE, Adidas and Inditex. However, $\mathrm{BCl}$ offers only one part of the solution and is not consumer facing.

Creating a straightforward labeling process, one that adheres to a comprehensive voluntary initiative, will help to inform consumers on how to consume more sustainable products. According to Gam (2007) consumers are willing to purchase 'green' (sustainable) products, but are often confused by labels. A number of consumers appear to find product labels hard to understand. Research has found that there are consumers who will buy lower quality green products in comparison to alternative products, but only when environmental information is clearly stated on labels ( $D^{\prime}$ Souza et al., 2006). Price sensitive eco consumers, who claim to always read labels, expressed that their decision to purchase 'eco' products was contingent on sufficient and straightforward information displayed on product labels (D'Souza et al., 2006).

Reforming the fashion industry, to improve the environmental and social impacts generated throughout the supply chain, is a critical element in order to create a more sustainable fashion industry (Kadolph, 2010). The textile industry has a past deeply rooted in migration; the determining factor of this migration is lower cost of production. As a result, the industry has moved to where regulations are less stringent and therefore provides no incentive for facilities in the Global South to encourage innovative alternatives to toxic dyes. Regulation alone will not serve to effectively prohibit the use of toxic chemicals, but a comprehensive voluntary initiative addressing the entire life cycle of garments that works in conjunction with environmental and ethical regulations will have a greater potential to lead to reform within the fashion industry. With increased media attention and NGO campaigns working to engage and inform consumers to demand sustainable clothing, major retailers will find it best for their brands to adhere to the new trends (Gam, 2007). Campaigns by organizations such as Greenpeace with the Detox Challenge are vital in bridging the gap between policy and science. These campaigns function to inform consumers who can then place greater demand on industry leaders to sign on to voluntary initiatives and place pressure on policy officials to create effective regulation and enforcement tools. 
The increase in green purchasing by industry leaders like Patagonia and M\&S demonstrates the demand for green products and services. However, while 'green purchasing' is on the rise, fast fashion continues to dominate sales. Consumers lack awareness on the negative health and environmental impacts of their clothing and therefore are hesitant to make the switch to purchasing sustainable fashion. Price and quality play a primary role in purchasing of eco garments. A study by Nakano (2001) found that consumers are not willing to pay over $10 \%$ more for sustainable and that consumers associate purchasing 'green' products with saving money. Alternatively, a study by Bhaduri et al. (2011) found that there exists a lack of trust in business and retailer claims of sustainability; consumers do not want to fall victim to 'green washing' schemes. Furthermore, consumers find labeling unclear and inconsistent.

\subsection{Potential Application of Research}

Several industry recommendations can be drawn from this study's analysis. First, the study draws on the lack of cohesive tracking and monitoring standards throughout the fashion industry. According to the analysis, retailers generally report on sustainability initiatives, but have yet to set an industry standard, making it difficult to track overall improvements in the industry in regards to water, waste, $\mathrm{CO} 2$ and energy. There is a pressing need to develop a cohesive and holistic monitoring tool for the fashion industry in order to develop greater transparency and consumer confidence. A holistic monitoring tool must also include social standards.

Second, fair trade-type certification schemes offer a starting point to address retailer engagement in sustainability. As identified throughout the report, voluntary initiatives play a key role in policy framework as they can function to strengthen regulation. Due to the multi-jurisdictional aspect of the fashion industry, regulation can be difficult to uphold and monitor. Fair trade type certification schemes rely on consumer facing labels and consumer education and awareness through retailers who act as proxies for consumers. Fair trade-type certification addresses both social and environmental concerns, and have looked to mainstream their movements by partnering with major retailers. The fashion industry can adopt lessons from fair trade by adopting a standard that addresses both environmental and social standards. Like the fair trade label, a label used in the fashion industry must be consumer facing in order to generate awareness and trust. Retailers can play a key role in acting as proxies for consumers by adhering to a singular code that allows for standardized reporting methods. 
Thirdly, by the fashion industry investing and adopting proper monitoring and data collection tools the industry can begin to address major environmental concerns across the sector. Future applications of this research can help companies carry out a risk assessment of their business models and supply chains; put together a sustainability roadmap covering the full product/service lifecycle; and ensure they understand the social and environmental context in which their products and services are used. As the fashion industry and consumer demands shift towards more sustainable practices companies will need to start developing the skills they will need to be successful in the future. The industry will need climate change experts, water policy specialists, and innovators with skills in design for disassembly and closedloop manufacturing and many more.

Finally, with greater consumer and industry awareness regarding sustainable practices for the fashion industry through the creation of a comprehensive and easily understood voluntary initiative, a greater sense of consumer confidence in sustainable apparel will be created. A consumer facing label, adopted and implemented by retailers, with adequate information could lead to greater purchasing of sustainable fashion alternatives by conscious consumers.

\subsection{Further Investigation}

Eco fashion is a fast growing trend among researchers and scientists. In 2013 the Journal of Corporate Citizenship released a special issue on sustainable fashion. Large retail brands such as NIKE, Adidas, Inditex, Gildan and H\&M have begun to release corporate sustainability reports and a number of widely recognized NGOs (World Wildlife Fund and Greenpeace) have launched campaigns and reports addressing the negative environmental impacts of the fashion industry. However, as it is still an emerging topic, many issues and questions remain.

Furthermore, research must look to address both social and environmental concerns through one initiative for the fashion industry. While this paper focused primarily on the environmental impacts generated by the fashion industry, a comprehensive VI for the fashion industry must also include clear commitments and guidelines to address the social impacts of apparel production. Just as fair trade-type coffee certifications aim to address both the social and environmental concerns, so too must a VI for the fashion industry. 
Past research has assessed voluntary initiatives in the fashion industry on an individual basis. Research has yet to be compiled in a comparative sense that encompasses the breadth of initiatives that exist. This comparative analysis provides a starting point for creating a new holistic voluntary initiative for the fashion industry. Future researchers can take the information gathered on consumer behaviour and eco awareness combined with designer and retailer input to create an initiative that includes the full life cycle of a garment from agricultural phase right to post consumption.

Further research could be completed on the impact of clear labeling schemes directed at consumers. The development of a clearly labeled voluntary initiative for fashion, such as that of fair trade, could lead to greater consumer awareness and greater purchasing of sustainable fashion. Further studies are needed to determine its impact on consumer behaviour.

This research looked to large fast fashion retailers with a presence in Canada. Future research could look to the influence that name designers, luxury designers and small designers and retailers could have on impacting sustainability in the fashion industry.

Sustainable fashion must concentrate on materials-based or technical innovations and social change, everything from championing lower impact fiber types to fairer employment methods to more efficient processing techniques. Designers are thought to influence an estimated 80 percent of the environmental impact of a product and so designers must be part of the solution. The study assessed larger retailers and their CSR models, however, due to the scope did not look at the role name designers and smaller retailers can play in addressing sustainability. The demands driven from smaller retailers may present results and levels of engagement as they relate to CSR. Future research needs to assess to what extent designers can be involved throughout the process. Research can look to how to better incorporate sustainability standards into academic institutions housing fashion programs. It is integral that emerging designers be knowledgeable not only of the sustainable options, but also of the negative impacts of conventional clothing practices.

In general, CSR is a rising issue across the fashion retail sector; the suggestion made here is that to address the sustainability dimensions of fashion there must first be development of a comprehensive standard to allow measurement and reporting on the environmental and social impacts across the supply chain that would enhance the ability of all actors to track improvements and industry trends 


\section{Bibliography:}

Abernathy, F.H., J.T. Dunlop, H.H. Hammond and D. Weil (1999) A Stitch in Time. New York: Oxford University Press.

Adidas (2009). Sustainability Progress Report 2013 Team Talk. Retrieved From http://sustainabilityreport.adidas-group.com/en/SER2009/

Adidas (2010). Sustainability Progress Report 2010 Performance Counts. Retrieved From http://sustainabilityreport.adidas-group.com/en/SER2010/

Adidas (2011). Sustainability Progress Report 2011 Performance Counts. Retrieved From http://sustainabilityreport.adidas-group.com/SER2011/

Adidas (2012). Sustainability Progress Report 2012 Never Stop. Retrieved From http://sustainabilityreport.adidas-group.com/SER2012/

Adidas (2013). Sustainability Progress Report 2013 Performance Counts. Retrieved Fromhttp://www.adidasgroup.com/media/filer_public/2014/04/14/2013_sustainability_progre ss_report_fair_play_final_en.pdf

Allwood, J.M., Bocke, N.M.P., Laursen, S.E., Malvido de Rodriguez, C. (2006). Well Dressed? The Present and Future Sustainability of Clothing and Textiles in the United Kingdom. Camebridge, UK.

Ashby, A., Hudson Smith, M., Shand, R. (2013). Embedding Sustainability in Clothing Supply Chain Strategies.

Sustainability in Fashion and Textiles. Sheffield, UK: Greenleaf Publishing Limited

Better Cotton System (2010, February 20) The Better Cotton Initiative. Accessed 4 March 2012. <www.bettercotton.org>

Bhaduri, G., Ha-Bookshire, J.E., (2011). Do Transparent Practices Pay? Exploration of Transparency and Consumer Purchase Intention. Clothing \& Textiles, 29(2), 135-149.

Braungart, M. \& McDonough, W. (2002). Cradle to Cradle. New York, NY: Douglas \& McIntyre Ltd.

Braun, R., Brik, M., Fuchs, W., Schoelberl, P. 2005 Treatment and Recycling of Textile Wastewater-Case Study and Development of Recycling Concept. Desalination 171.2:173-183

Cachon, G.P., Swinney. R. (2011). The Value of Fast Fashion: Quick Response, Enhanced Design, and Strategic Consumer Behaviour. Management Science 57: 778-795

Cataldi, C., Dickson, M., Grover, C. (2013). Slow Fashion: Tailoring a Strategic Approach for Sustainability. Sustainability in Fashion and Textiles. Sheffield, UK: Greenleaf Publishing Limited.

Canadian Center for Pollution Prevention: Textile Industry. http://www.c2p2online.com/main/ns/156/heading/163. Accessed January 26, 2012

Cavagnaro, E., Curiel, G. (2012). Introduction The Three Levels of Sustainability. Sheffield, UK: Greenleaf Publishing Limited.

Cline, E. (2012). Overdressed: The Shockingly High Cost of Cheap Fashion. London, UK: Penguin Book

Creswell, J. W. (2003). Research design: Qualitative, quantitative, and mixed method approaches (2nd ed. ed.). Thousand Oaks, Calif.: Sage Publications.

Das, T.K. (2005). Toward Zero Discharge: innovative methodology and technologies for process pollution prevention. Washington: Wiley Print

DEFRA: Department for Environment and Rural Affairs (2011). Sustainable Clothing Road Map. Progress Report 2011. 
DeSimone, J.M. (2002). Practical Approaches to Green Solvents. Science 2. 297: 799803

Dickson, M., Loker, S., Echman, M. (2009). Social Responsibility in the Global Apparel Industry. Ridge, NY: Fairchild Books

Dickson, M., Eckman, M. (2006). Social Responsibility: The Concept as Defined by Apparel And Textile Scholars. Clothing \& Textiles Research Journal, 24(3), 178-191.

Doeringer, P., Crean, S. (2006). Can fast fashion save the US apparel industry? SocioEconomic Review 4: 353-377.

D'Souza, C., Taghian, M., Lamb, P. (2006). An Empirical Study on the Influence of Environmental Labels

Environmental Protection Agency (EPA) (1996, September). Manual Best Management Practices for Pollution Prevention in the Textile Industy. Centre for Research Information. Ohio.

Environmental Protection Authority. (1998, June). Environmental Guidelines For the Textile Dyeing and Finishing Industry. State Government of Victoria. Retrieved from http://www.epa.vic.gov.au

Environmental Justice Foundation. (2010) White Gold- the True Cost of Cotton: Report on cotton production in Uzbekistan. London, UK. http://www.ejfoundation.org/page141.html

Fair Trade Canada (2012) About Fair Trade Certification. Retrieved November 25, 2012 from http://fairtrade.ca/en/about-fairtrade/fairtrade-certification

Fletcher, K. (2008) Sustainable Fashion and Textiles. London: Earthscan.

Gam, Hae Gin. (2007). Development and Implementation of a Sustainable Apparel Design and Production Model. Oklahoma State University. Dissertation. Doctor of Philosophy

Gacia-Jounson, R., Sasser, E. (2001). Voluntary Standard Systems-a Contribuiton to Sustainable Development. Springer.

Gardetti, M.A., Torres, A.L., (2013). Introduction. Sustainability in Textiles and Fashion. Sheffield, UK: Greenleaf Publishing Limited.

Gardiner, L. (1997). Outdoor Clothing Maufacturer Patagonia Recognized for Corporate Responsibility. Issues in Ethics. 8.1: 27-35.

Giddings, B., Hopwoood, B., O'Brian, G. (2002). Environment, Economy and Society: Fitting Them Together into Sustainable Development. Sustainable Development. 10: 187-96.

Gildan (2009). Corporate Citizenship Report 2008-2009. Retrived from http://www.genuinegildan.com/media/multiuploader_images/20082009_Corporate_Citizenship_Report.pdf

Gildan. (2010). Corporate Citizenship Interim Report 2010. Retrieved From http://www.genuinegildan.com/media/multiuploader_images/PDF_ENGLISH_2012_final.pdf

Gildan. (2011). Corporate Citizenship Report 2011. Retrieved from http://www.genuinegildan.com/media/multiuploader_images/PDF_ENGLISH_2012_final.pdf

Gildan (2012 Corporate Citizenship Report 2012. Retrived From http://www.genuinegildan.com/media/multiuploader_images/PDF_ENGLISH_2012_final.pdf

Gildan (2013). Reporting. Retrieved from http://www.genuinegildan.com/en/company/reporting/

Goworek, H. (2011) 'Social and Environmental Sustainability in the Clothing Industry: A Case Study of a Fair Trade Retailer', Social Responsibility Journal 7.1: 74-86.

Government of Canada. (2006). Corporate Social Responsibility: An Implementation Guide for Canadian Business. Ottawa, ON. http://www.ic.gc.ca/eic/site/csrrse.nsf/vwapj/ CSR_mar2006. pdf/\$FILE/CSR_mar2006.pdf

Greenbaum, A., Wellington, A. (2010). Environmental Law and Policy in the Canadian Context. Concordia: Captus Press. Ch. 2, 8 \& 11. 
Hoffman, L. (2008). Future Fashion White Pages. New York, NY: Earth Pledge

H\&M (2009). Conscious Actions Sustainability Report 2009. Retrieved from

http://sustainability.hm.com/content/dam/hm/about/documents/en/CSR/reports/Conscious\%2 OActions\%20Sustainability\%20Report\%202009_en.pdf

H\&M (2010). Conscious Actions Sustainability Report 2003. Retrieved from

http://sustainability.hm.com/content/dam/hm/about/documents/en/CSR/reports/Conscious\%2

OActions\%20Sustainability\%20Report\%202010_en.pdf

H\&M (2011). Conscious Actions Sustainability Report 2011. Retrieved from

http://sustainability.hm.com/content/dam/hm/about/documents/en/CSR/reports/Conscious\%2 0Actions\%20Sustainability\%20Report\%202011_en.pdf

H\&M (2012). Conscious Actions Sustainability Report 2012. Retrieved from

http://about.hm.com/content/hm/AboutSection/en/About/Sustainability/Reporting-and-

Resources/Reports.html>

H\&M (2013). Conscious Actions Sustainability Report 2013. Retrieved from http://sustainability.hm.com/content/dam/hm/about/documents/en/CSR/reports/Conscious\%2 OActions\%20Sustainability\%20Report\%202013_en.pdf

Inditex (2009) Sustainable Index Annual Report 2009. Retrieved from http://static.inditex.com/annual_report_2009/en/

Inditex (2010) Sustainable Index Annual Report 2010. Retrieved from http://static.inditex.com/annual_report_2010/en/

Inditex (2011) Sustainable Index Annual Report 2011. Retrieved from http://static.inditex.com/annual_report_2011/en/

Inditex (2012) Sustainable Index Annual Report 2012. Retrieved from http://static.inditex.com/annual_report_2012/en/

Inditex (2013) Sustainable Index Annual Report 2013. Retrieved from http://static.inditex.com/annual_report_2013/en/

Jaffee, D. (2012). Weak Coffee: Certification and Co-Optation in the Fair Trade Movement. Social Problems, 59 (1), 94-116.

Joergens, C. (2006) Ethical Fashion: Myth or Future Trend? Journal of Fashion Marketing and Management, 10: 360-71.

Kadolph, Sara J., (2010). Textiles $11^{\text {th }}$ Edition. New Jersey: Pearson, Print.

Klein, N. (2000) No Logo: Taking Aim at the Brand Bullies. Toronto: Knopf-Random.

Kolk, A. (2011). Mainstreaming Sustainable Coffee. Sustainable Development, 21, 324337.

Kozlowski, A., Bardecki, M., Searcy, C. (2012). Environmental Impacts of the Fashion Industry: A Life-Cycle and Stakelholder Framework. The Journal of Corporate Citizenship. 45, 17

Krippendorff, K. (1980). Content Analysis: An Introduction to Its Methodolody. Newbury Park, CA: Sage Lampa, H. (2009, September). Cotton Today and Tomorrow for H\&M. Environmental Coordination

Supply Chain. Retrieved from http://www.cnpa.embrapa.br/produtos/algodao/publicacoes/cba7/VIICBA_palestras/Pacifico_1

6.09_16h_Master(H.Lampa).pdf

Little, A. (2005). Interview with Yvon Chouinard. Retrieved from http://grist.org/politics/little-chouinard

Litrell, M., Dickson, M. (2006). Employment With a Socially Responsible Business: Worker Capabilities and Quality of Life. Clothing \& Textiles Research Journal, 24(3), 192-206.

Loureriro, M., Lotade, J. (2005). Do Fair Trade and Eco Labels in Coffee Wake up the Consumer Conscience? Ecological Economics, 53, 129-138. 
Lutz, K. (2011). Insights from Founder, Yvon Chouinard. Retrieved from www.opportunitygreen.com/greenbusiness.com/green-business-blog/2011/01/27/what-makespatagonia-the-coolest-company-on-the-planet-insights-from-founder-yvon-chouinard

Lynn, C. (2010). Environmental Impact: Consumers' "Dirty Laundry". Green Earth NewsWeb. http://blog.greenearthbamboo.com/20100927/bambfabric/consumers-dirtylaundry-the-truth-behind-your-t-shirt/ Accessed March 2, 2012.

Marks \& Spencer (2013). SWHOPPING Retrieved from http://corporate.marksandspencer.com/plan-a/about-plan-a/shwopping

Marks \& Spencer 2 (2013). UNICEF. Retrieved from http://corporate.marksandspencer.com/plan-a/about-plan-a/partnerships/unicef

McDonough, W., \& Braungart, M. (2002). Cradle to cradle: Remaking the way we make things. New York, NY: North Point Press.

Meyer, A. (2001). What's in it for the customers? Successfully marketing green clothes. Business Strategy and the Environment, 10, 317-330.

Moore, S.B. (2004). Systems Thinking and Green Chemistry in the Textile Industry: Concepts.Technologies and Benefits. Journal For Cleaner Production. 12.6: 585-601.

Multilateral Investment Guarantee Agency (MIGA). 31 January 1996. Environmental Guidelines for Textiles Industry. Pollution Prevention and Abatement. 505-509. Retrieved from: http://www.miga.org/documents/Textiles.pdf

Nakano, Y. (2007) Perceptions towards Clothes with Recycled Content and Environmental Awareness, The Development of End Markets in M. Miraftaband and A.R. Horrocks (eds.), Ecotextiles: The Way Forward for Sustainable Development in Textiles Cambridge, UK: Woodhead Publishing: 3-14.

Newitt, K. (2013). Private Sector Volunatary Initiatives on Labor Standards. Background Paper for the World Development Report on Jobs. UK: Ergon Associate Limited

Nicholls, A., Opal, C. (2005). Fair Trade: Market-Driven Ethical Consumption. London, Thousand Oaks, CA and New Delhi: Sage Publications.

NIKE (2013). Sustainable Business Performance Summary FY12/13. Retrieved from http://www.nikeresponsibility.com/report/uploads/files/FY12-13_NIKE_Inc_CR_Report.pdf

NIKE (2011). Sustainable Business Performance Summary FY10/11. Retrieved from http://www.nikeresponsibility.com/report/uploads/files/Nike_FY10-11_CR_report.pdf

NIKE (2009). Sustainable Business Performance Summary FY07-09. Retrieved http://www.nikeresponsibility.com/report/uploads/files/Nike_FY07_09_CR_report.pdf

Park, H., and S.J. Lennon (2006). The Organizational Factors Influencing Socially Responsible Apparel Buying/Sourcing. Clothing and Textiles Research Journal 24, 229-47.

Patagonia. (2012) Environmentalism: What We Do. http://www.patagonia.com/us/patagonia.go?assetid=2329

Patagonia (2014). Frequently Asked Questions. Retrieved from www.patagonia.com/us/patagonia.go?assetid $=37493$

Portway, S., Lewis, T. (2012). Regenerative Abundance. Lambert Academic Publishing

Potts, J., Lynch, M., Wilkings. A. Huppe, G., Cunningham, M., Voora, V. (2014). The State Of Sustainability Initiatives Review 2014. Standards and the Green Economy. State Of Sustainability Initiatives. Retrieved from http://www.iisd.org/pdf/2014/ssi_2014.pdf

Raynolds, L. (2008). Maintreaming Fair Trade Coffee: From Partnerhsip to Traceability. World Development, 37(6), 1083-1093.

Ren, X. (2000). Development of Environmental Performance Indicators for the Textile Process And Product. Journal for Cleaner Production. 8.6: 473-481. 
Rehman, T., Shafiq, M., (2000). The extent of resource use inefficiencies in cotton production in Pakistan's Punjab: an application of Data Envelopment Analysis. Agricultural Economics22(3): 321-330.

Renard, M.-C. (2005). Quality Certification, Regulation and Power in Fair Trade. Journal of Rural Studies, 21, 419-431.

Rose, R. What is Lesson Drawing? Journal of Public Policy. 11.1: 3-30

Salerno-Kochan, R. (2008). Consumer Approach to the Quality and Safety of Textile Products.Part 2. Consumer Perception of Parameters Related to the Safety of Clothing Use. Fibers and Textiles in Eastern Europe. 16(5): 70-74

Shaw, D., and D. Tomolillo (2004) Undressing the Ethical Issues in Fashion: A Consumer Perspective, in M. Bruce (ed.), International Retail Marketing: A Case Study Approach Oxford, UK: Butterworth-Heinemann: 141-52.

Siegle, L. (2011). To Die For: Is Fashion Wearing Out the World? . Hammersmith, UK: Harpers Collins

Statistics Canada. Retail and Wholesale Trade. The Governemnt of Canada, 2009. Web. October 2014 http://www.statcan.gc.ca/pub/11-402-x/2012000/chap/retail-detail/retail-detail-eng.htm?fpv=60000

Taylor, P. (2004). In the Market But Not of It: Fair Trade Coffee and Forest Stewardship Council Certification as Market-Based Social Change. World Development, 33(1), 129-147

Textile Exchange (2013). Organic Cotton Report. Retrieved from http://textileexchange.org/publications/2013-organic-cotton-report

The Detox Campaign. Greenpeace. (2012, March 2) Retrieved from http://www.greenpeace.org/international/en/campaigns/toxics/water/detox/intro/

Tüfekci, N., Sivri, N., Toroz, I. (2007). Pollutants of Textile Industry Wastewater and Assessment of its Discharge Limits by Water Quality Standard. Turkish Journal of Fisheries and Aquatic Sciences 7: 97-103.

Unknown, ed. Encyclopedia of Textiles. (1972), Prentice Hall:Englewood Clifts, NJ.

United Nations. (1987) Report of the World Commission on Environment and Development, General Assembly Resolution 42/187.

Webb, K. (2004) Understanding the Voluntary Codes Phenomenom. Voluntary Codes: Private Governance, the Public Interest and Innovation. Ed. Kernaghan Webb. Ottawa: Carlton nit for Innovation. 3-32. Print

Webb, K., (1999) Voluntary Initiatives and the Law: The Practice and Promise of Voluntary Environmental Initiatives Depend Heavily on Productive Partnership with Legal Instruments. Voluntary Initiatives: The New Politics of Corporate Greening. Ed. RobertB. Gibson. Peterborough: Broadview Press Ltd. 32-50. Print

Weisberg, H. F. (1996). In Krosnick J. A., Bowen B. D. (Eds.), An introduction to survey research, polling, and data analysis (3rd ed. ed.). Thousand Oaks, CA: Sage Publications.

Wiese, A., Kellner, J., BLietke, B., Toporowski, W. (2012). International Journal of Retail And Distribution Management, 40(4), 318-335.

Willard, H. (2009). How Thirsty is Your Tshirt? Ethical Fashion World. Retrieved from http://www.ecofashionworld.com/EcoFashion-Pulse/HOW-THIRSTY-IS-YOUR- TSHIRT.htmI 